\title{
ॠUSGS
}

science for a changing world

Mercury, Methylmercury, and Other Constituents in Sediment and Water from Seasonal and Permanent Wetlands in the Cache Creek Settling Basin and Yolo Bypass, Yolo County, California, 2005-06

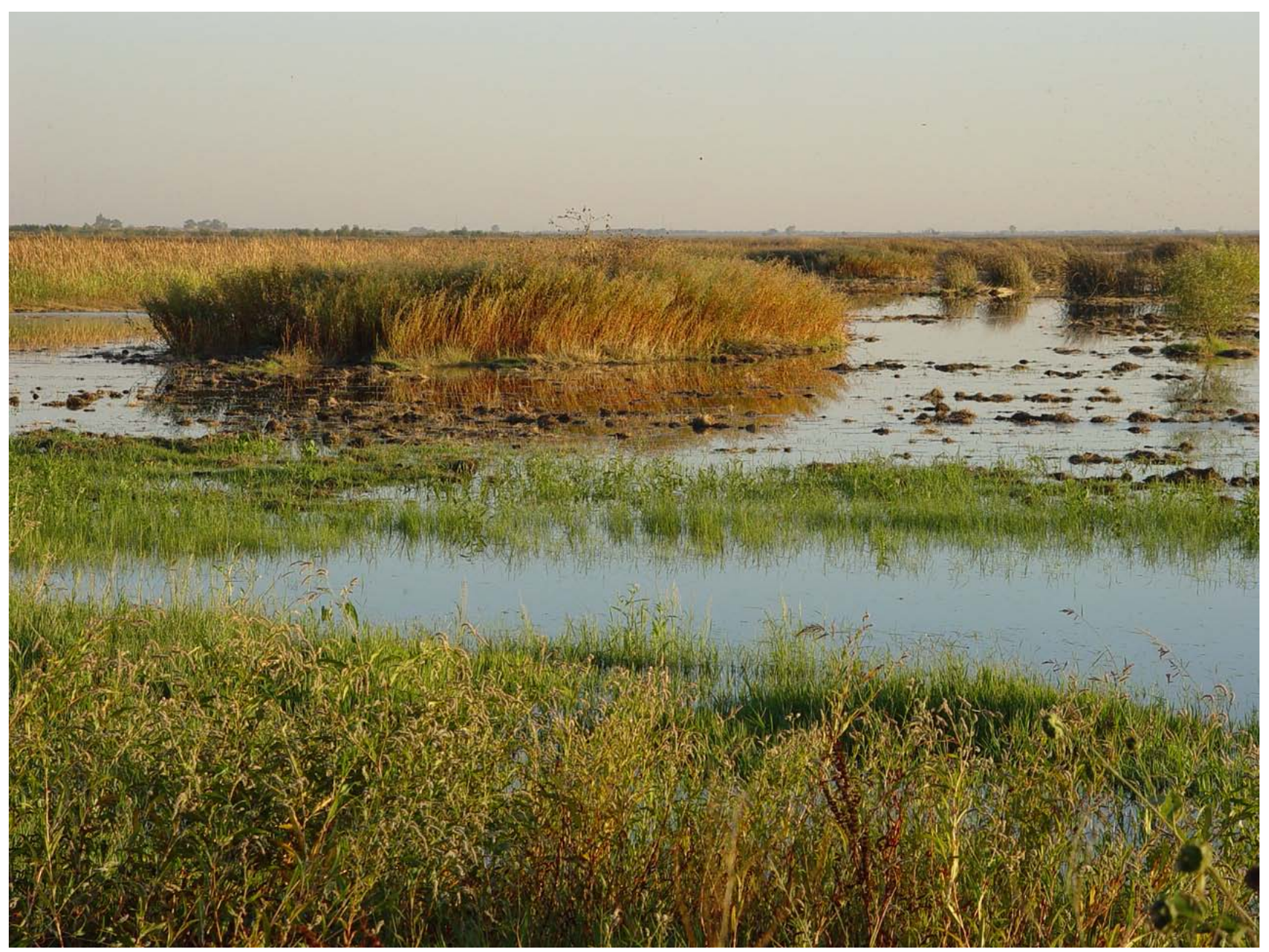

Open File Report 2009-1182

U.S. Department of the Interior

U.S. Geological Survey 
This page is intentionally left blank. 


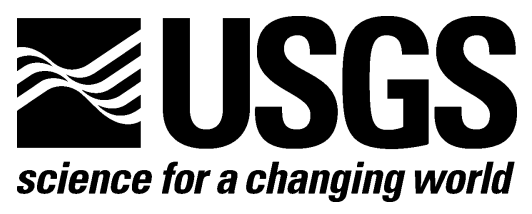

Prepared in Cooperation with the Sacramento Regional County Sanitation District, the Sacramento River Watershed Program, and the United States Environmental Protection Agency

\section{Mercury, Methylmercury, and Other}

\section{Constituents in Sediment and Water from}

\section{Seasonal and Permanent Wetlands in the Cache}

\section{Creek Settling Basin and Yolo Bypass, Yolo}

\section{County, California, 2005-06}

By Mark Marvin-DiPasquale, Charles N. Alpers, and Jacob A. Fleck

Open File Report 2009-1182

U.S. Department of the Interior

U.S. Geological Survey 


\section{U.S. Department of the Interior \\ KEN SALAZAR, Secretary}

\section{U.S. Geological Survey \\ Suzette Kimball, Acting Director}

U.S. Geological Survey, Menlo Park, California 94025
Revised and reprinted: September 2009

For product and ordering information:

World Wide Web: http://www.usgs.gov/pubprod

Telephone: 1-888-ASK-USGS

For more information on the USGS—-the Federal source for science about the Earth, its natural and living resources, natural hazards, and the environment:

World Wide Web: http://www.usgs.gov

Telephone: 1-888-ASK-USGS

Suggested citation:

Marvin-DiPasquale, Mark, Alpers, Charles N., and Fleck, Jacob A., 2009, Mercury, methylmercury, and other constituents in sediment and water from seasonal and permanent wetlands in the Cache Creek Settling Basin and Yolo Bypass, Yolo County, California, 2005-06: U.S. Geological Survey, Open File Report 2009-1182, 69 p.

Any use of trade, product, or firm names is for descriptive purposes only and does not imply endorsement by the U.S. Government.

Although this report is in the public domain, permission must be secured from the individual copyright owners to reproduce any copyrighted material contained within this report.

Cover: Seasonally flooded wetland in the Yolo Bypass Wildlife Management Area, Yolo County, California (USGS photograph by Mark Marvin-DiPasquale). 


\section{Contents}

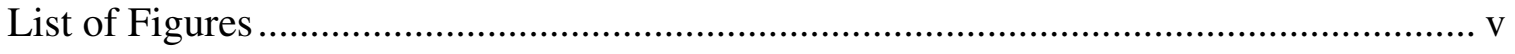

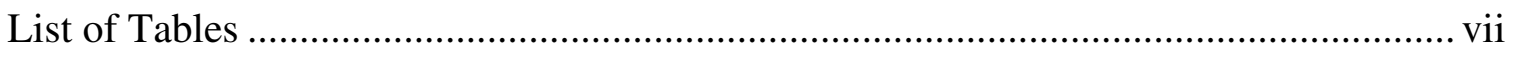

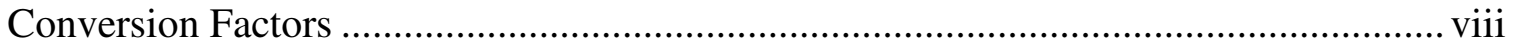

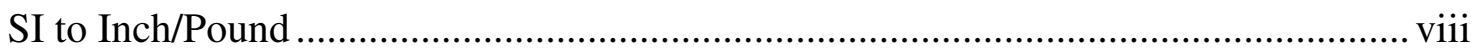

Acronyms, Abbreviations, and Chemical Notation ....................................................... ix

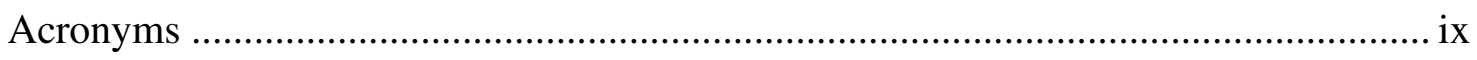

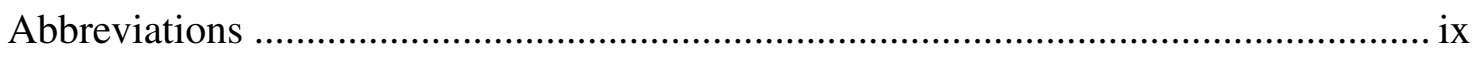

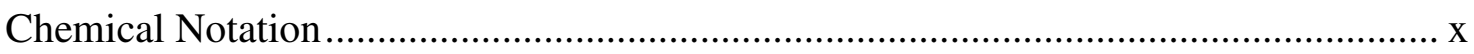

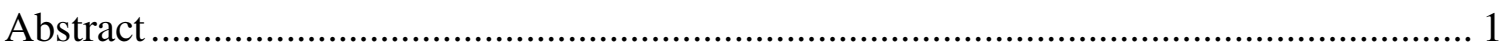

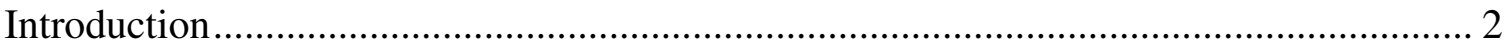

Previous Work and Related Investigations.................................................................... 3

Purpose and Scope

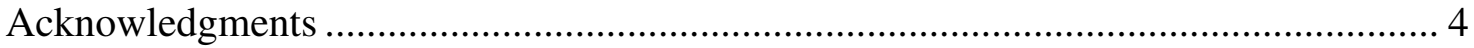

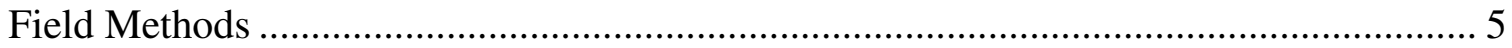

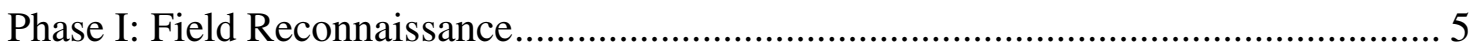

Phase II: Seasonal Field Sampling ..................................................................... 5

Water Sample Collection, Initial Processing, and Preservation ...................................... 6

Sediment Sample Collection and Initial Processing ...................................................... 7

Field Oxidation-Reduction Potential and $\mathrm{pH}$ Measurements..................................... 7

Initial Subsampling of Sediment and Pore Water ...................................................... 8

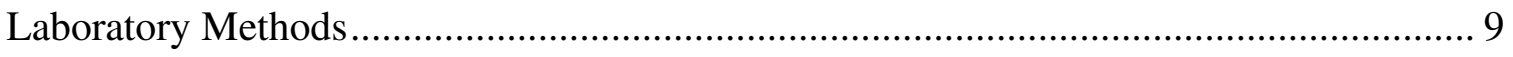

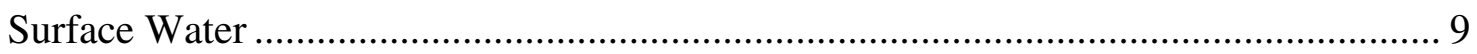

Total Mercury and Methylmercury ……………………....................................... 9

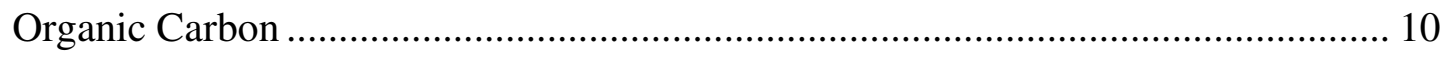

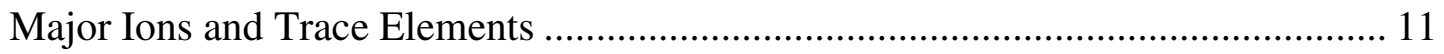

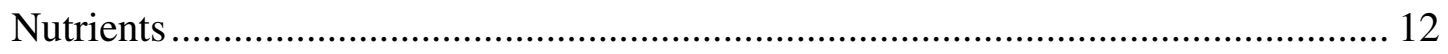

Stable Isotopes of Water and Sulfate ................................................................. 12

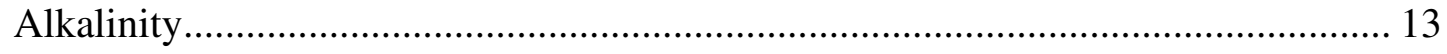

Suspended Solids Concentration (SSC) ............................................................... 13 


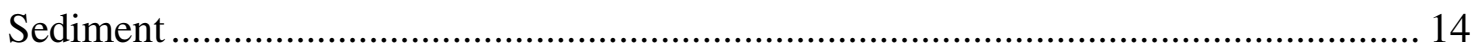

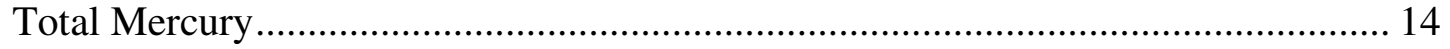

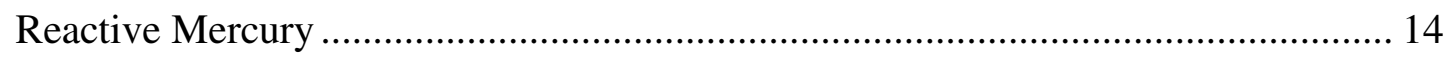

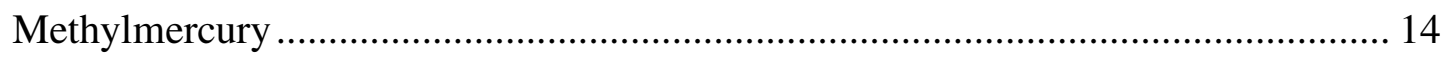

Bulk Density, Percent Dry Weight, Porosity, and Organic Content ........................... 15

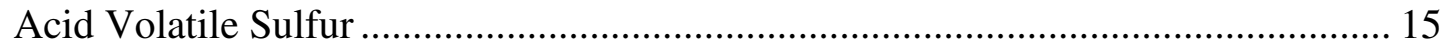

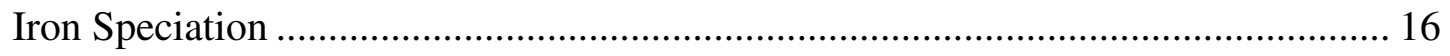

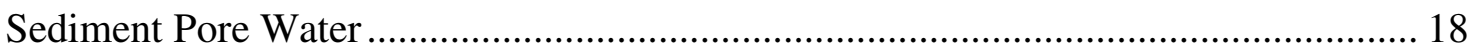

Dissolved Organic Carbon and Acetate ................................................................ 18

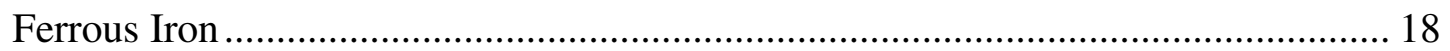

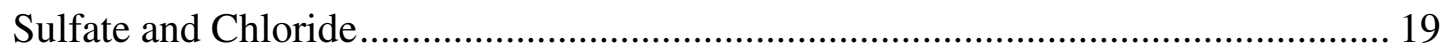

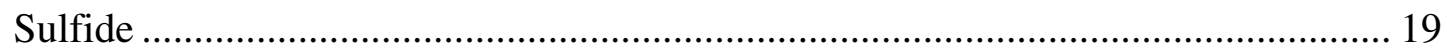

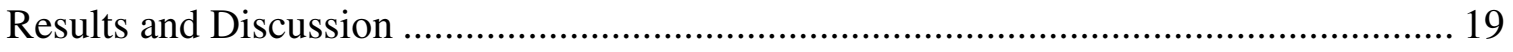

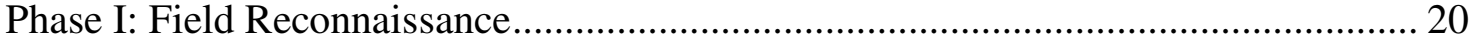

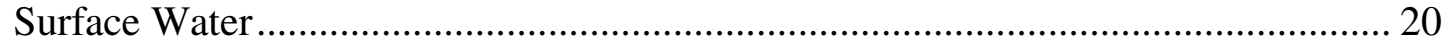

Sediment and Pore water................................................................................ 20

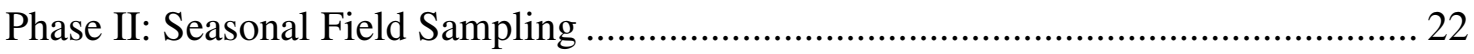

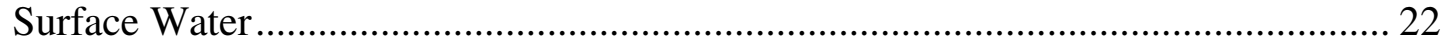

Sediment and Pore Water................................................................................... 24

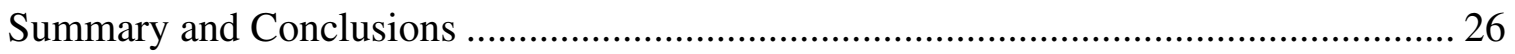

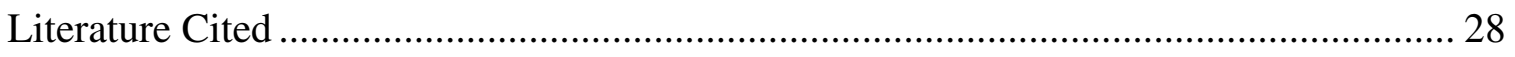




\section{List of Figures}

Figure 1. Map of sites sampled during study Phase I (0ctober 5, 2005) within the Cache Creek Nature Preserve (CCNP), Cache Creek Settling Basin (CCSB) and the Yolo Bypass Wildlife Area (YBWA), Yolo County, California..................................36

Figure 2. Photographs of sites sampled during study Phase I (October 5, 2005)...................37

Figure 3. Satellite images of $(A)$ Cache Creek Settling Basin and $(B)$ Yolo Bypass Wildlife Area, depicting the location of sampling sites........................................................38

Figure 4. Photographs of the two Cache Creek Settling Basin sites (CCSB-2 and CCSB-3) sampled during study Phase II (February 13, 2006, and May 30, 2006).

Figure 5. Hydrograph of Cache Creek, California (USGS gaging station 11452500), from September 15, 2005 through June 15, 2006.

Figure 6. The negative correlation between unfiltered total mercury (u-THg) concentration in surface water and the percentage as methylmercury (\% u-MeHg) for sites sampled during study Phase I, within the Cache Creek Nature Preserve (CCNP), Cache Creek Settling Basin (CCSB), and Yolo Bypasss Wildlife Area (YBWA), Yolo County, California.

Figure 7. Mercury species in sediment sampled during study Phase I from sites in the Cache Creek Nature Preserve (CCNP), Cache Creek Settling Basin (CCSB), and Yolo ByPass Wildlife Area (YBWA), Yolo County, California.

Figure 8. Plot showing the positive correlation between organic content (as \% LOI, Percentage Loss on Ignition) and total mercury ( $\mathrm{THg}$ ) concentration in sediment from Phase I.

Figure 9. Plots showing $(A)$ the negative relationship between sediment acid volatile sulfur (AVS) and sediment inorganic reactive mercury $\left(\mathrm{Hg}(\mathrm{II})_{R}\right)$ concentrations and $(B)$ the positive relationship between sediment oxidation-reduction potential (Redox) and the percentage of total mercury as $\mathrm{Hg}(\mathrm{II})_{R}\left(\% \mathrm{Hg}(\mathrm{II})_{R}\right)$ during Phase I.

Figure 10. Concentrations of sulfur species in sediment and pore water sampled during Phase I from sites in Cache Creek Nature Preserve (CCNP), Cache Creek Settling Basin (CCSB) and Yolo ByPass Wildlife Area (YBWA), Yolo County, California.

Figure 11. Concentrations of iron species in sediment and pore water sampled during Phase I from sites in Cache Creek Nature Preserve (CCNP), Cache Creek Settling Basin (CCSB) and Yolo ByPass Wildlife Area (YBWA), Yolo County, California.

Figure 12. Log-log plot showing the relation between total mercury $(\mathrm{THg})$ and methylmercury (MeHg) concentrations in unfiltered waters from seasonal and permanent wetlands of Cache Creek and the Yolo Bypass, California. 
Figure 13. Log-log plots showing the relation between surface water suspended sediment concentration (SSC) and (A) unfiltered total mercury (u-THg) and (B) unfiltered methylmercury (u-MeHg) concentrations in seasonal and permanent wetlands of Cache Creek Settling Basin (CCSB) and the Yolo Bypass Wildlife Area (YBWA), Yolo County, California. Phase II sampling data only.

Figure 14. Plot showing the linear relation between methylmercury (MeHg) concentration in bed sediment and in unfiltered surface water during study Phase II from permanent and seasonal wetland sites in the Cache Creek Settling Basin (CCSB) and the Yolo Bypass Wildlife Area (YBWA), Yolo County, California. .... 49

Figure 15. Plots showing correlations among water quality parameters in samples collected during Phase II from seasonal and permanent wetlands of Cache Creek Settling Basin (CCSB) and the Yolo Bypass Wildlife Area (YBWA), Yolo County, California.

Figure 16. Concentrations of sediment mercury species during study Phase II in permanent and seasonal wetland sites, in the Cache Creek Settling Basin (CCSB) and the Yolo Bypass Wildlife Area (WBWA), Yolo County, California....51

Figure 17. Concentrations of sediment organic content during study Phase II for permanent and seasonal wetland sites in the Cache Creek Settling Basin (CCSB) and the Yolo Bypass Wildlife Area (YBWA), Yolo County, California. ....52

Figure 18. Time series of $(A)$ methylmercury $(\mathrm{MeHg})$ concentration and $(B)$ the percentage of total mercury as $\mathrm{MeHg}(\% \mathrm{MeHg})$ in surface sediment $(0-2 \mathrm{~cm})$ of the permanent and seasonal wetlands sites in the Yolo Bypass Wildlife Area, Yolo County, California. 53

Figure 19. Concentrations of sulfur species in sediment and pore water during study Phase II, for permanent and seasonal wetland sites in the Cache Creek Settling Basin (CCSB) and the Yolo Bypass Wildlife Area (YBWA), Yolo County, California. .54

Figure 20. Concentration of iron species in sediment and pore water during study Phase II, for permanent and seasonal wetland sites in the Cache Creek Settling Basin (CCSB) and the Yolo Bypass Wildlife Area (WBWA), Yolo County, California....55 


\section{List of Tables}

Table 1. Parameters analyzed in sediment and surface water during study Phases I and II, Cache Creek and Yolo Bypass, Yolo County, California. 56

Table 2. Study site locations, sampling dates, and descriptions for Cache Creek and Yolo Bypass, Yolo County, California.

Table 3. Data for mercury species in surface water, Cache Creek and Yolo Bypass, Yolo County, California.

Table 4. Data for organic matter in surface water, Cache Creek and Yolo Bypass, Yolo County, California.

Table 5. Data for nutrients and major anions in surface water, study Phase II, Cache Creek and Yolo Bypass, Yolo County, California.

Table 6. Data for major cations and trace elements in filtered surface water, study Phase II, Cache Creek Settling Basin and Yolo Bypass, Yolo County, California...... 61

Table 7. Data for stable isotopes of oxygen in water and sulfur in sulfate in surface water, study Phase II, Cache Creek and Yolo Bypass, Yolo County, California.......... 65

Table 8. Ancillary surface water data, Cache Creek and Yolo Bypass, Yolo County, California.

Table 9. Mercury species in surface sediment (0-2 cm interval), Cache Creek and Yolo Bypass, Yolo County, California.

Table 10. Ancillary parameters in the surface sediment (0-2 cm interval), Cache Creek and Yolo Bypass, Yolo County, California......

Table 11. Ancillary parameters in sediment pore water (0-2 cm interval), Cache Creek and Yolo Bypass, Yolo County, California. 


\section{Conversion Factors}

\section{SI to Inch/Pound}

\begin{tabular}{|c|c|c|}
\hline Multiply & By & To obtain \\
\hline \multicolumn{3}{|c|}{ Length } \\
\hline centimeter $(\mathrm{cm})$ & 0.3937 & inch (in.) \\
\hline meter $(\mathrm{m})$ & 3.281 & foot (ft) \\
\hline millimeter $(\mathrm{mm})$ & 0.03937 & inch (in.) \\
\hline \multicolumn{3}{|c|}{ Area } \\
\hline square kilometer $\left(\mathrm{km}^{2}\right)$ & 247.1 & Acre \\
\hline square kilometer $\left(\mathrm{km}^{2}\right)$ & 0.3861 & square mile $\left(\mathrm{mi}^{2}\right)$ \\
\hline \multicolumn{3}{|c|}{ Volume } \\
\hline cubic centimeter $\left(\mathrm{cm}^{3}\right)$ & 0.06102 & cubic inch $\left(\mathrm{in}^{3}\right)$ \\
\hline liter (L) & 33.82 & ounce, fluid (fl. oz) \\
\hline liter $(\mathrm{L})$ & 2.113 & pint (pt) \\
\hline liter (L) & 1.057 & quart (qt) \\
\hline liter (L) & 0.2642 & gallon (gal) \\
\hline liter (L) & 61.02 & cubic inch $\left(\mathrm{in}^{3}\right)$ \\
\hline \multicolumn{3}{|c|}{ Mass } \\
\hline $\operatorname{gram}(\mathrm{g})$ & 0.03527 & ounce, avoirdupois (oz) \\
\hline kilogram (kg) & 2.205 & pound avoirdupois (lb) \\
\hline \multicolumn{3}{|c|}{ Density } \\
\hline $\begin{array}{l}\text { gram per cubic centimeter } \\
\left(\mathrm{g} / \mathrm{cm}^{3}\right)\end{array}$ & 62.422 & pound per cubic foot $\left(\mathrm{lb} / \mathrm{ft}^{3}\right)$ \\
\hline
\end{tabular}

Temperature in degrees Celsius $\left({ }^{\circ} \mathrm{C}\right)$ may be converted to degrees Fahrenheit $\left({ }^{\circ} \mathrm{F}\right)$ as follows:

${ }^{\circ} \mathrm{F}=\left(1.8 \times{ }^{\circ} \mathrm{C}\right)+32$

Latitude and Longitude coordinates are given according to "North American Datum of 1983 (NAD 83)"

Specific conductance (SC) is given in microsiemens per centimeter at 25 degrees Celsius $\left(\mu \mathrm{S} / \mathrm{cm}\right.$ at $\left.25^{\circ} \mathrm{C}\right)$.

Concentrations of chemical constituents in water are given either in milligrams per liter (mg/L), micrograms per liter $(\mu \mathrm{g} / \mathrm{L})$, or micromoles per liter $(\mu \mathrm{mol} / \mathrm{L})$, where a mole $(\mathrm{mol})$ unit is equivalent to $6.022 \times 10^{23}$ atoms. 


\section{Acronyms, Abbreviations, and Chemical Notation}

\section{Acronyms}

APHA, American Public Health Association

AVS, acid-volatile sulfur

CDT, Cañon Diablo Troilite

CCNP, Cache Creek Nature Preserve

CCSB, Cache Creek Settling Basin

CVAFS, cold vapor atomic-fluorescence spectrometry

CVRWOCB, Central Valley Regional Water Quality Control Board

CWSC, California Water Science Center

DI, deionized (water)

D.0., dissolved oxygen

DOC, dissolved organic carbon

EDTA, ethylene-diamine-tetraacetic acid

EPA, U.S. Environmental Protection Agency

GC, gas chromatography

HDPE, high-density polyethylene

HEPES, (4-(2-hydroxyethyl)-1-

piperazineethanesulfonic acid)

HPIA, hydrophyllic acids

HPOA, hydrophobic acids

IAEA, International Atomic Energy Agency

ICP-AES, Inductively coupled plasma-atomic emission spectrometry

ICP-MS, Inductively coupled plasma-mass spectrometry

LOI, loss on ignition

MRL, Mercury Research Laboratory

NRP, National Research Program

NWQL, National Water Quality Laboratory

$\mathrm{ORP}$, oxidation-reduction potential

PET, polyethylene terephthalate
POC, Particulate organic carbon

$\mathrm{QA}$, quality assurance

$\mathrm{OC}$, quality control

RPD, relative percent difference

$\mathrm{RSD}$, relative standard deviation

SAOB, sulfur antioxidant buffer

SC, specific conductance

$S D$, standard deviation

SFB, San Francisco Bay

SSC, suspended solids concentration

SWRCB, State Water Resources Control Board

TMDL, Total Maximum Daily Load

TPIA, transphyllic acids

USEPA, United States Environmental Protection Agency

USGS, United States Geological Survey

VSMOW, Vienna Standard Mean Ocean Water

YBWA, Yolo Bypass Wildlife Area

\section{Abbreviations}

cfs, cubic foot per second

$\mathrm{cm}$, centimeter

$\mathrm{f}-\mathrm{MeHg}$, filtered methylmercury

$\mathrm{f}-\mathrm{THg}$, filtered total mercury

g, gram

kg, kilogram

L, liter

$\mathrm{mg}$, milligram

$\mathrm{mL}$, milliliter

$\mathrm{mV}$, millivolts

$\mathrm{M} \Omega-\mathrm{cm}$, megaohm-centimeter

$\mathrm{N}$-org., organic nitrogen 
ng, nanogram

$\mathrm{ng} / \mathrm{L}$, nanogram per liter

p-MeHg, particulate methylmercury

$\mathrm{p}-\mathrm{THg}$, particulate total mercury

Pr, statistical probability

u-MeHg, unfiltered methylmercury

u-THg, unfiltered total mercury

$\mu g$, microgram

$\mu \mathrm{m}$, micrometer

$\mu \mathrm{M}$, micromole per liter

$\mu \mathrm{mol} / L$, micromole per liter

wt, weight

s, second

$>$, greater than

$<$, less than

\section{Chemical Notation}

$\mathrm{Al}$, aluminum

As, arsenic

$B$, boron

Ba, barium

$\mathrm{Be}$, beryllium

Bi, bismuth

$\mathrm{BrCl}$, bromine monochloride

Ca, calcium

Cd, cadmium

Ce, cerium

Cl, chloride

Co, cobalt

$\mathrm{Cr}$, chromium

Cs, cesium

Cu, copper

Dy, dysprosium

Er, erbium

Eu, europium
Fe, iron

$\mathrm{Fe}(\mathrm{II})$, ferrous iron

$\mathrm{Fe}(\mathrm{III})$, ferric iron

$\mathrm{Fe}(\mathrm{II})_{\mathrm{AE}}$, acid extractable ferrous iron

$\mathrm{Fe}(\mathrm{II})_{\mathrm{PW}}$, pore water ferrous iron

$\mathrm{Fe}(\mathrm{III})_{\mathrm{a}}$, amorphous ferrous iron

$\mathrm{Fe}(\mathrm{III})_{\mathrm{c}}$, crystalline ferrous iron

Gd, gadolinium

$\mathrm{HCl}$, hydrochloric acid

Ho, holmium

$\mathrm{Hg}$, mercury

$\mathrm{Hg}^{0}$, elemental mercury

$\mathrm{Hg}^{2+}$ or $\mathrm{Hg}(\mathrm{II})$, mercuric ion

$\mathrm{Hg}(\mathrm{II})_{\mathrm{R}}$, inorganic reactive mercury

$\mathrm{HgCl}_{2}$, mercuric chloride

$\mathrm{HgS}$, mercury sulfide (cinnabar or metacinnabar)

Ir, iridium

K, potassium

$\mathrm{KCl}$, postassium chloride

La, lanthanum

Li, lithium

Lu, lutetium

$\mathrm{MeHg}$, methylmercury (monomethylmercury)

$\mathrm{Mg}$, magnesium

Mn, manganese

Mo, Molybdenum

$\mathrm{N}$, nitrogen

$\mathrm{Na}$, sodium

$\mathrm{NaOH}$, sodium hydroxide

$\mathrm{Nd}$, neodymium

$\mathrm{NH}_{4}{ }^{+}$, ammonium ion

$\mathrm{Ni}$, nickel

$\mathrm{NO}_{2}^{-}$, nitrite ion

$\mathrm{NO}_{3}{ }^{-}$, nitrate ion

$\mathrm{P}$, phosphorous 
$\mathrm{PO}_{4}{ }^{3-}$, orthophosphate ion

$\mathrm{Pb}$, lead

Pr, praseodymium

$\mathrm{Rb}$, rubidium

$\mathrm{Re}$, rhenium

Rh, rhodium

S, sulfur

$\mathrm{SO}_{4}{ }^{2-}$, sulfate ion

Sb, antimony

Se, selenium

$\mathrm{SiO}_{2}$, silicon dioxide

Sm, samarium

Sn, tin

Sr, strontium
$\mathrm{SnCl}_{2}$, stannous chloride

$\mathrm{Tb}$, terbium

Te, tellurium

$\mathrm{THg}$, total mercury

$\mathrm{TI}$, thallium

Tm, thulium

$\mathrm{U}$, uranium

$\mathrm{V}$, vanadium

W, tungsten

$Y$, yttrium

$\mathrm{Yb}$, ytterbium

$\mathrm{Zn}$, zinc

ZnS, zinc sulfide

$\mathrm{Zr}$, zirconium 


\title{
Mercury, Methylmercury, and Other Constituents in Sediment and Water from Seasonal and Permanent Wetlands in the Cache Creek Settling Basin and Yolo Bypass, Yolo County, California, 2005-06
}

\author{
By Mark Marvin-DiPasquale, Charles N. Alpers, and Jacob A. Fleck
}

\begin{abstract}
This report presents surface water and surface (top 0-2 cm) sediment geochemical data collected during 2005-2006, as part of a larger study of mercury ( $\mathrm{Hg}$ ) dynamics in seasonal and permanently flooded wetland habitats within the lower Sacramento River basin, Yolo County, California. The study was conducted in two phases. Phase I represented reconnaissance sampling and included three locations within the Cache Creek drainage basin; two within the Cache Creek Nature Preserve (CCNP) and one in the Cache Creek Settling Basin (CCSB) within the creek's main channel near the southeast outlet to the Yolo Bypass. Two additional downstream sites within the Yolo Bypass Wildlife Area (YBWA) were also sampled during Phase I, including one permanently flooded wetland and one seasonally flooded wetland, which had began being flooded only 1-2 days before Phase I sampling.

Results from Phase I include: (a) a negative correlation between total mercury ( $\mathrm{THg}$ ) and the percentage of methylmercury (MeHg) in unfiltered surface water; (b) a positive correlation between sediment $\mathrm{THg}$ concentration and sediment organic content; (c) surface water and sediment THg concentrations were highest at the CCSB site; (d) sediment inorganic reactive mercury $\left(\mathrm{Hg}(\mathrm{II})_{\mathrm{R}}\right)$ concentration was positively related to sediment oxidation-reduction potential and negatively related to sediment acid volatile sulfur (AVS) concentration; (e) sediment $\mathrm{Hg}(\mathrm{II})_{\mathrm{R}}$ concentrations were highest at the two YBWA sites; (f) unfiltered surface water $\mathrm{MeHg}$ concentration was highest at the seasonal wetland YBWA site, and sediment $\mathrm{MeHg}$ was highest at the permanently flooded YBWA site; $(\mathrm{g})$ a 1,000-fold increase in sediment pore water sulfate concentration was observed in the downstream transect from the CCNP to the YBWA; (h) low sediment pore water sulfide concentrations $(<1 \mu \mathrm{mol} / \mathrm{L})$ across all sites; and (i) iron $(\mathrm{Fe})$ speciation data suggest a higher potential for microbial Fe(III)-reduction in the YBWA compared to the CCSB.

Phase II sampling did not include the original three Cache Creek sites, but instead focused on the original two sites within the YBWA and a similarly paired set of seasonally and permanently flooded wetland sites within the CCSB. Sediment sampling at the YBWA and CCSB occurred approximately 28 days and 52 days, respectively, after the initial flooding of the respective seasonal wetlands, and again towards the end of the seasonal flooding period (end of May 2006). Results from Phase II sampling include: (a) sediment $\mathrm{MeHg}$ concentration and the percentage of $\mathrm{THg}$ as $\mathrm{MeHg}(\% \mathrm{MeHg})$ in
\end{abstract}


unfiltered surface waters were generally higher in the YBWA compared to the CCSB; (b) suspended sediment concentration (SCC) in surface water was positively correlated with both $\mathrm{THg}$ and $\mathrm{MeHg}$ in unfiltered water across all sites, although the relationship between SCC and MeHg differed for the two regions, suggesting local MeHg sources; (c) $\mathrm{MeHg}$ concentration in unfiltered surface water was positively correlated to sediment $\mathrm{MeHg}$ concentrations across all sites, supporting the suggestion of unique local (sediment) sources of MeHg to the water column; (d) THg concentration in filtered water was positively correlated with both total Fe and dissolved organic carbon (DOC), offering additional support for the role of these constituents in the partitioning of $\mathrm{THg}$ between particulate and dissolved phases; (e) flooding of the YBWA seasonal wetland resulted in a rapid and significant (5-fold) rise in sediment $\mathrm{MeHg}$ concentration within 34 weeks following inundation; and (f) temporal changes in sediment $\mathrm{S}$ and Fe speciation suggest that rates of both microbial sulfate reduction and $\mathrm{Fe}(\mathrm{III})$-reduction were significantly higher at YBWA, compared to CCSB, during the period between flooding and drying.

The geochemical data presented in this report indicate that (a) strong spatial and temporal differences in $\mathrm{Hg}$ speciation and transformations can occur within the range of wetland habitats found in the lower Sacramento River basin; (b) flooding of seasonal wetlands can be accompanied by a rapid increase in benthic $\mathrm{MeHg}$ production and the release of previously formed $\mathrm{MeHg}$ (generated during or since the previous flooding season) to the overlying water column; (c) S and Fe chemistry, and associated microbial reduction pathways, play an important role in mediating the speciation and transformation of $\mathrm{Hg}$ in these wetland habitats; (d) hydroperiod is a primary forcing function in mediating $\mathrm{MeHg}$ production among various wetland types; and (e) $\mathrm{MeHg}$ production appears to be more active in the YBWA compared to the CCSB.

\section{Introduction}

Wetlands are an important ecological feature of healthy aquatic systems, within the Sacramento River basin and elsewhere, because they provide critical habitat for wildlife, serve as zones of net deposition for particulate material, and are regions of net export for dissolved organic matter and nutrients. Variations in salinity, hydrology, climate, and vegetation result in a diverse mosaic of wetland types and make these regions both interesting and challenging to study. Dense communities of emergent vascular plants are a typical identifying feature of wetlands. Sediments in these habitats tend to be comparatively organic rich, due to the continuous input of above- and belowground biomass from primary production and often exhibit high rates of microbial activity associated with the ongoing decay of senescent vascular plant material. As such, microbial processes associated with the cycling of trace metals are often elevated in wetlands, compared to nearby non-wetland aquatic habitats such as river beds or open bay/delta areas (Marvin-DiPasquale and others, 2003). There is a growing recognition that wetland environments can be particularly active zones for the conversion of inorganic divalent mercury ( $\mathrm{Hg}(\mathrm{II}))$ to the more toxic organic methylmercury ( $\mathrm{MeHg}$ ) form (Zillioux and others, 1993; Krabbenhoft and others, 1999), a process largely mediated by sediment bacteria (Gilmour and others, 1992). Although biological and geochemical controls on this process are understood in broad terms, the specifics are less clear, and the variation in mercury speciation and $\mathrm{MeHg}$ production rates expected across different wetland types is largely unknown. 
Historic mining practices, including the mining of cinnabar (mercuric sulfide, $\mathrm{HgS}$ ) along the California coastal range, its purification to elemental mercury $\left(\mathrm{Hg}^{0}\right)$, and the use of $\mathrm{Hg}^{0}$ in the mining and recovery of gold and silver in the Sierra Nevada, have left a persistent legacy of mercury contamination throughout the San Francisco Bay (SFB) and its watershed (Alpers and others 2005). Fish consumption advisories in the greater SFB are largely a result of $\mathrm{Hg}$ contamination (Slotton and others, 2002, 2004; Davis and others, 2008), and similar $\mathrm{Hg}$ contamination has been reported in piscivorous bird populations that inhabit the estuary, potentially threatening the viability of some species (Schwarzbach and others, 2005; Ackerman and others, 2008; Eagles-Smith and others, 2009). Quantitative data regarding the sources and cycling of $\mathrm{Hg}$ and $\mathrm{MeHg}$ contamination in upstream watersheds are a prerequisite for better $\mathrm{Hg}$ contamination in the SFB.

With a drainage basin of approximately $70,000 \mathrm{~km}^{2}$ and comprising several major tributaries, the Sacramento River represents about one-third of the surface-water runoff within California and supplies about 80 percent of the freshwater to the SFB-Delta region (Domagalski, 2001; Stephenson and others, 2007). As many of the tributaries entering the Sacramento River transport particulate and dissolved $\mathrm{Hg}$ from upstream contamination sites, the Sacramento River drainage is responsible for delivering 60-85 percent of the $\mathrm{THg}$ load (Foe, 2003) and 77 percent of the total MeHg load (3.2 kg of MeHg) annually to the SFB-Delta (Stephenson and others, 2007).

As the importance of wetlands in the biogeochemical cycling of $\mathrm{Hg}$ has become more widely recognized in recent years, attention has turned towards examining the contribution of specific wetland types to overall $\mathrm{Hg}$ cycling and how this mosaic of wetland types affects $\mathrm{Hg}$ cycling at the scale of the larger SFB-Delta ecosystem (Slotton and others, 2000, 2002; Davis and others, 2003; Marvin-DiPasquale and others, 2003, 2007; Yee and others, 2007). However, little to no research has been conducted on wetland settings within the Sacramento River basin itself. The current study addresses this information gap by examining $\mathrm{Hg}$ speciation and other key constituents in surface water and sediment of seasonally inundated and permanently flooded wetland sites in two areas along the lower Sacramento River, Cache Creek and the Yolo Bypass, both of which are known to be contaminated with $\mathrm{Hg}$ and to export $\mathrm{MeHg}$.

\section{Previous Work and Related Investigations}

Cache Creek has been identified as a major source of $\mathrm{Hg}$-contaminated sediments to the Yolo Bypass and the downstream Estuary (Suchanek and others, 2002; Domagalski, 2004; Domagalski and others, 2004a, 2004b). This contamination has been linked to increased $\mathrm{MeHg}$ exports from the Yolo Bypass during high flow conditions (Chris Foe, California Regional Water Quality Control Board, Central Valley Region, unpublished data). Of particular interest, wetlands within the Cache Creek watershed have been identified as localized "hotspots," where Hg concentrations in fish are elevated; other reaches of the watershed may have contaminated sediments, but biota do not have high tissue burdens (Slotton and others, 2000, 2004). These data suggest that the combination of $\mathrm{Hg}$-laden sediments and wetlands may enhance biotic uptake of $\mathrm{Hg}$ (Davis and others, 2003; Weiner and others, 2003). The Cache Creek Settling Basin (CCSB) was designed to capture $\mathrm{Hg}$-contaminated sediments in a wetland-like environment, and it is well-suited for studies on the factors that influence $\mathrm{Hg}$ (II)methylation. The most recent estimates indicate that the CCSB releases $160 \mathrm{~g}$ of $\mathrm{MeHg}$ 
annually to the Yolo Bypass, representing a significant point source (Central Valley Regional Water Quality Ccontrol Board, 2007). The current draft Total Maximum Daily Load (TMDL) plan for the SFB-Delta calls for a 92-percent reduction of $\mathrm{MeHg}$ export from the CCSB (Central Valley Regional Water Quality Ccontrol Board, 2007).

The Yolo Bypass is another region of concern because it is a floodplain, managed largely as wetland habitat, and receives $\mathrm{Hg}$-contaminated sediments from a number of sources (Sommer and others, 2001). During high flows in the Sacramento River, water is diverted to the Yolo Bypass for flood control and the water quality reflects Sacramento River conditions. When Sacramento River water is not being diverted into the Yolo Bypass, water quality is dominated by drainage from Cache Creek, Davis Creek, and Putah Creek (Schemel and others, 2002, 2004; Schemel and Cox, 2007). The Hgcontaminated sediments in the Bypass are believed to control the production and export of $\mathrm{MeHg}$ from the Yolo Bypass to the central Delta, and they represent the single largest regional source of $\mathrm{MeHg}$ to the SFB estuary. The most recent estimates are that the Yolo Bypass annually releases $19 \mathrm{~g}$ and $480 \mathrm{~g}$ of $\mathrm{MeHg}$ from agricultural and wetland sources, respectively, to the SFB-Delta (California Regional Water Quality Control Board, Central Valley Region, 2007). The current draft TMDL plan for the SFB-Delta calls for an 81percent reduction in $\mathrm{MeHg}$ export from the Yolo Bypass (California Regional Water Quality Control Board, Central Valley Region, 2007). Despite the importance of the Yolo Bypass in the SFB-Delta MeHg budget, relatively little has been done to better understand the processes controlling $\mathrm{MeHg}$ production and biotic uptake in this geographic area. The current "pilot" study has provided the basis for the first comprehensive study of $\mathrm{Hg}$ (II)-methylation and biological $\mathrm{MeHg}$ uptake in the Yolo Bypass, a study currently underway (California State Water Resources Control Board agreement \# 06-232-555-0).

\section{Purpose and Scope}

The primary goal of the current study was to examine $\mathrm{Hg}$ cycling in two contrasting wetland types (seasonally and permanently flooded) and in two different hydrologic units (Cache Creek and the Yolo Bypass) within the lower Sacramento River basin in the Central Valley region of California. Specifically, we examined $\mathrm{Hg}$ speciation and concentration in sediment and water, $\mathrm{MeHg}$ production rates in sediment, and a suite of additional sediment and surface-water quality measures, near the onset and towards the end of the seasonal flooding period (October 2005 through May 2006). This report documents the results of the field component of the study, including concentrations of sediment and water constituents, $\mathrm{Hg}$ speciation, and ancillary geochemical measures. A companion report (Marvin-DiPasquale and others, in preparation) documents the related laboratory component of the study, which consisted of a series of amendment experiments designed to assess which geochemical variables had the most pronounced effect on stimulating or mitigating $\mathrm{MeHg}$ production, within and among the study sites.

\section{Acknowledgments}

Several individuals within various organizations provided administrative support with regard to contracts and agreements that provided funding for this project: Jerry Troyan and Vicki Fry at the Sacramento Regional County Sanitation District, Kathy Russick, Shelley Matthews, and Mary Lee Knecht at the Sacramento River Watershed Program, Debra Denton at the U.S. Environmental Protection Agency, and Stephanie 
Fong at the Regional Water Quality Control Board, Central Valley Region (RWQCBCVR). Participants in the Delta Tributaries Mercury Council provided input regarding study design and sampling locations, including Chris Foe at the RWQCB-CVR and Stephen McCord at Larry Walker Associates. Several people provided assistance with field work logistics: Darrell Slotton and Shaun Ayers at the University of California Davis and staff at the California Department of Water Resources provided assistance with regard to sampling logistics at the Cache Creek Nature Preserve and Cache Creek Settling Basin; Dave Feliz and Chris Rocco helped with access to the sites within the Yolo Bypass Wildlife Area. U.S. Geological Survey personnel who assisted with field and laboratory work include: Jim Orlando and Will Kerlin (Sacramento, Calif.); Jennifer Agee, Nicolas Ladizinsky, John R. Flanders, Marisa Cox, Evangelos Kakouros, and Sherrie Wren (Menlo Park, Calif.); George Aiken, Ronald Antweiler, Kenna Butler, Dale Peart, Terry Plowman, and Howard Taylor (Boulder, Colo.); Cayce Gulbransen and Robert O. Rye (Denver, Colo.); and David P. Krabbenhoft, Mark Olson, and John DeWild (Middleton, Wis.).

\section{Field Methods}

Field sampling was performed in two parts: (a) Phase I, an initial field reconnaissance trip to examine and collect sediment from three potential sampling areas, and (b) Phase II, subsequent field sampling at both seasonal and permanent wetlands within each of two of the original three reconnaissance areas, conducted on two additional occasions each (approximately one month after initial flooding of the seasonal wetland and near the end of the inundation period for the seasonal wetland). The suite of constituents measured in sediment, sediment pore water, and overlying water for Phase I and II sampling efforts are given in table 1.

\section{Phase I: Field Reconnaissance}

On October 5, 2005, reconnaissance sampling (Phase I) was conducted in three areas (figs. 1,2 , table 2): (a) Cache Creek Nature Preserve (CCNP), approximately 5 miles west of the City of Woodland, where two sites (CCNP-1 and CCNP-2) were sampled in a constructed, permanent wetland setting dominated by Typha sp. (cattail) with minor Scirpus sp. (tule); (b) downstream of the CCNP, within the Cache Creek Settling Basin (CCSB), where one site (CCSB-1) was sampled in Cache Creek itself, near the outlet in the southeast corner of the Settling Basin (fig. 3A), which flows into Yolo Bypass; and (c) within Yolo Bypass, in the Yolo Bypass Wildlife Area (YBWA), about 1 mile south of Interstate 80, where one permanent wetland (YBWA-1) and one seasonal wetland (YBWA-2) were sampled (figs. $\underline{1}, \underline{2}, \underline{3 B}$ ). Flooding of the YBWA seasonal wetland had begun only a few days before this initial sampling event.

\section{Phase II: Seasonal Field Sampling}

After obtaining preliminary results from Phase I, it was decided that the remainder of the study (Phase II) would focus on paired seasonal and permanent wetland sites within the CCSB and YBWA (figs. $3 A, 3 B$, table 2). Because the CCSB was not flooded at the time of Phase I sampling, two new locations, one permanent wetland 
(CCSB-2) and one seasonal wetland (CCSB-3), were selected after the CCSB flooded in January 2006 (fig. 4). Subsequently, these two CCSB sites were sampled in February and May 2006, and CCSB-1 was abandoned. The two YBWA sites sampled during Phase I were resampled for sediment in late October 2005 and May 2006. In addition to the above sites sampled for both water and sediment, only water was sampled at the inlet to the YBWA permanent wetland (YBWA-3) in late October 2005 and at the outlet of the permanent wetland (YBWA-4) in May 2006, to coincide with the flooding and draining, respectively, of this area. The hydrograph of Cache Creek flow (fig. 5) indicates that the seasonal wetland site (CCSB-3) most likely began flooding on December 23, 2005 (discharge >400 cfs; Chris Foe, California Regional Water Quality Control Board, Central Valley Region, written communication, 2009), which was 52 days before the initial sampling of this location. No hydrograph data are provided for the YBWA region, because water within the YBWA is highly managed and not directly associated with the natural variations of water levels within the Toe Drain (from where it is derived). Sampling of seasonal wetland site YBWA-2 occurred approximately 28 days after water was first put onto this field (approximately October 3, 2005).

\section{Water Sample Collection, Initial Processing, and Preservation}

Field water-quality parameters were measured using a multiprobe sonde (YSI model $600 \mathrm{XLM}$ ) that was set up to measure temperature, $\mathrm{pH}$, dissolved oxygen (DO), and specific conductance (SC) in the water column. The sonde was calibrated according to the specifications of the manufacturer.

Specialized cleaning and sampling techniques were used during all stages of collection of discrete water samples to minimize contamination. Prior to use, all containers and equipment used for water and sediment sampling were cleaned using a dilute liquid soap followed by a 5-percent $\mathrm{HCl}$ solution and multiple rinses of ultrapure, deionized (DI) water (18 M $\Omega$-cm [megaohm-centimeter]), following standard USGS protocols (Shelton, 1994).

Surface water samples were collected approximately $10-15 \mathrm{~cm}$ below the surface using acid-cleaned 13-L jerrricans made of fluorinated plastic that is similar to Teflon in its wetting and cleaning properties. A jerrican was submerged to half the depth of the water column using clean, gloved hands, and rinsed three times with native water prior to filling. A field duplicate was collected, corresponding to one of the 15 surface water samples. Great care was taken to avoid disturbing the bottom sediments during the collection and disposing of rinse water. Following collection of the field sample, the jerrican was double-bagged and placed on ice in a dark cooler for storage during transport to the USGS California Water Science Center (CWSC) laboratory in Sacramento. Upon arrival at the laboratory, the samples were split using clean-hands/dirty-hands techniques using an acid-cleaned Teflon-lined stainless-steel churn according to approved USGS methods (Olson and DeWild, 1999). Sample aliquots were collected in the order indicated in table 1.

Filtration of water samples was done using Geotech high-capacity capsule filters (http://www.geotechenv.com/disposable_filter_capsules.html) of $0.45 \mu \mathrm{m}$ nominal pore size for most constituents (major anions, major cations, trace metals, and nutrients). For all samples collected for analysis of major cations, DOC and trace metals, replicate splits were collected and submitted to the USGS National Research Program (NRP) laboratory in Boulder, Colorado. Aliquots were also taken from the capsule filtrate for analysis of 
DOC at both the CWSC and the USGS National Water Quality Laboratory (NWQL) in Denver, Colorado. Filtration for analysis of DOC at the NWQL was done using precombusted quartz fiber filters (GF7525MM, Advantec MFS Inc.) of $0.3 \mu \mathrm{m}$ nominal pore size.

Filtered and unfiltered water samples for analysis of $\mathrm{THg}$ and (or) $\mathrm{MeHg}$ were stored in acid-washed Teflon bottles and preserved with a distilled (sub-boiling) 50percent hydrochloric acid solution. Teflon bottles and hydrochloric acid solution were provided by the USGS Mercury Research Laboratory (MRL) in Middleton, Wisc.. Filtered and unfiltered samples for analysis of major cations and trace elements were stored in acid-washed high-density polyethylene (HDPE) bottles and preserved using distilled nitric acid. HDPE bottles and nitric acid solution were provided by the USGS NRP Boulder laboratory. Filtered samples collected for analysis of anions were chilled on wet ice and then refrigerated at or below $5^{\circ} \mathrm{C}$ until analysis. Unfiltered samples collected for analysis of nutrients were preserved using a sulfuric acid solution and then chilled on wet ice followed by refrigeration; filtered nutrient samples were not acidified but were chilled until analyzed. Samples collected for analysis of stable isotopes of oxygen $\left(\delta^{18} \mathrm{O}\right)$ in unfiltered water were stored in glass bottles with polyseal caps with minimal headspace to minimize evaporation. Filtered water samples for analysis of stable isotopes of sulfur $\left(\delta^{34} \mathrm{~S}\right)$ in sulfate were stored in HDPE bottles, chilled on wet ice or refrigerated at or below $5^{\circ} \mathrm{C}$.

During Phase II, water samples collected for analysis of suspended solids concentration (SSC) were taken from the churn and dispensed into preweighed 1-L Nalgene bottles. In contrast to all other splits, the bottles for SSC samples were not rinsed with the ambient water, to avoid introducing extraneous suspended solids to the container. The SSC samples were chilled on wet ice or refrigerated at or below $5^{\circ} \mathrm{C}$ until analysis at the USGS CWSC lab in Marina, California.

\section{Sediment Sample Collection and Initial Processing}

Surface sediment $(0-2 \mathrm{~cm})$ was collected using a polycarbonate core ring $(2 \mathrm{~cm}$ depth $\mathrm{x} 8 \mathrm{~cm}$ diameter). The core ring was pressed into the sediment until the top edge was flush with the sediment/water interface. A stiff plastic sheet was inserted under the bottom of the core ring, which was then gently lifted out of the sediment. The resultant sediment patty was transferred into an acid-cleaned mason jar. Upon filling the jar with 4-6 patties, subsamples were taken in the field for $\mathrm{Hg}$ speciation, using a $3-\mathrm{cm}^{3}$ cutoff syringe. A final sediment patty was added to completely fill the mason jar, and the jar was stored on wet ice until further processing at the USGS Menlo Park laboratory. The subsamples for $\mathrm{Hg}$ speciation were placed in a cooler with dry ice and frozen in the field, then transferred to a freezer back at the laboratory until further processing.

\section{Field Oxidation-Reduction Potential and pH Measurements}

Field oxidation-reduction potential (ORP) measurements were taken during Phase I (early October 2005 at all sites) and during the Phase II late October 2005 sampling of the YBWA sites. Measurements were made with a platinum band ORP electrode (Model EW05990-55, Cole Parmer®, Vernon Hills, Ill.) used in conjunction with a hand-held $\mathrm{pH} / \mathrm{mV}$ multi-meter (Model 59002-00, Cole Parmer®, Vernon Hills, IL). The accuracy of 
the ORP electrode was tested daily with freshly made buffer solutions $(\mathrm{pH}=7$ and $\mathrm{pH}=$ 4) saturated with quinhydrone, as per the manufacturer's instructions (Cole-Parmer Document \#P1937). The ORP for each solution was measured and the difference between them calculated. If this value fell within the range of $173 \pm 4 \mathrm{mV}$, the probe was determined to be functioning properly. After cleaning thoroughly with reagent water and drying, the probe was then fully inserted into the 20-mL glass vial containing approximately $15 \mathrm{~cm}^{3}$ of sediment subsampled from a sediment composite mason jar for that site. The ORP electrode was allowed to equilibrate for a minimum of 10 minutes, until a stable reading was achieved, prior to recording the potential $(\mathrm{mV})$. The ORP meter values were subsequently converted to $\mathrm{E}_{\mathrm{h}}$ values (a standard convention that adjusts the value assuming a normal hydrogen reference electrode), using the following conversion:

$$
\begin{aligned}
& E_{h}=\text { ORP (meter value) }+E R \\
& E R=(-0.718 \times T)+219.97
\end{aligned}
$$

where $\mathrm{ER}=$ the standard potential for a normal hydrogen reference electrode; $\mathrm{T}=$ temperature $\left({ }^{\circ} \mathrm{C}\right)$

Field sediment pH was measured during Phase I (early October 2005, all sites)

and in Phase II in late October 2005 during the sampling of the YBWA sites, and again in February 2006 during the sampling of the CCSB sites. Measurements were made with a $\mathrm{pH}$ electrode used in conjunction with a hand-held $\mathrm{pH} / \mathrm{mV}$ multimeter (as described above). The electrode was calibrated daily with fresh commercial $\mathrm{pH}=7$ phosphate buffer and then rinsed clean with reagent water. The probe was fully inserted into a $20-\mathrm{ml}$ PET plastic vial containing approximately $15 \mathrm{~cm}^{3}$ of sediment subsampled from the sediment composite mason jar for that site. The $\mathrm{pH}$ electrode was gently swirled in the sediment matrix until a stable $\mathrm{pH}$ reading was achieved.

\section{Initial Subsampling of Sediment and Pore Water}

Sediment and pore water parameters were measured on subsamples split in the laboratory under anoxic conditions (in an $\mathrm{N}_{2}$-flushed glove bag) on the day following field collection. Sediment was transferred from the mason jars into plastic bags to facilitate homogenization. Sediment subsamples included: (a) bulk density, porosity, and organic content (all three taken from a single subsample), transferred into an acid-cleaned glass screwtop jar and refrigerated, (b) acid volatile sulfur (AVS), subsampled (1.5 g) into acid-cleaned glass crimp vials, preserved with $5.0 \mathrm{ml}$ of a 10-percent (w/v) zincacetate (anoxic) solution, homogenized, and stored frozen, and (c) iron ( $\mathrm{Fe})$ speciation, subsampled into acid-cleaned glass crimp vials and stored frozen.

For the collection of pore water, plastic centrifuge tubes $\left(50 \mathrm{~cm}^{3}\right)$ were filled to the top with the homogenized sediment, inside of the $\mathrm{N}_{2}$-flushed glove bag. The screwcaps were further wrapped with Parafilm ${ }^{\circledR}$ to retard the diffusion of atmospheric oxygen during centrifugation. The tubes were then centrifuged for $20 \mathrm{~min}$ at 3,500 rpm and subsequently were returned to the $\mathrm{N}_{2}$-flushed glove bag prior to removing the caps. The pore water supernatant was decanted into the back end of a plastic syringe (with the plunger initially removed) that was fitted with a $1.6 \mu \mathrm{m}$ glass fiber prefilter (Whatman 25 $\mathrm{mm}$ GF/A syringe filter) and a $0.45 \mu \mathrm{m}$ nylon filter (Whatman $25 \mathrm{~mm}$ GD/X syringe filter). Replacing the plunger, the pore water was pushed through the filters and into the containers prelabeled and prepared for the collection of the various pore water 
constituents (sulfate and chloride, sulfide, ferrous iron (Fe(II)), acetate (Phase I only), and DOC). Subsamples for sulfate and chloride were collected into the same container (crimp-sealed glass serum vial with a $\mathrm{N}_{2}$ headspace) and stored frozen until further analysis. Subsamples for filter-passing Fe(II) were collected into glass screwtop vials, acidified to $\mathrm{pH}<2$, with trace-metal-clean nitric acid, and stored refrigerated until further analysis. Subsamples for pore water sulfide were preserved 1:1 with anoxic sulfur antioxidant buffer [SAOB; $2 \mathrm{~mol} / \mathrm{L} \mathrm{NaOH}, 35 \mathrm{~g} / \mathrm{L}$ ascorbic acid, and $67 \mathrm{~g} / \mathrm{L}$ ethylenediamine-tetraacetic acid (EDTA)-disodium salt)], in crimp-sealed serum vials and refrigerated until analysis (within 48 hours of preservation). Subsamples for pore water DOC (and acetate for Phase I) were collected into glass screwtop vials and stored refrigerated until further analysis.

Several precautionary measures were made to minimize changes in redoxsensitive sediment geochemistry between the time of field collection and subsequent subsampling and analyte-specific preservation. Precautions included: (a) minimal holding times prior to subsampling, (b) completely filling glass mason jars with sediment, and (c) cold storage (on wet ice or refrigerated) during the holding period. Even with these precautions, some changes in redox chemistry may have occurred during the holding period and sample processing.

\section{Laboratory Methods}

For USGS-approved methods used for routine analyses by laboratories such as the USGS NWQL, relatively little method information is given in this report, and the reader is referred to published sources. More detailed information is given in this section for research methods that have not been officially approved by the USGS for routine analysis.

\section{Surface Water}

\section{Total Mercury and Methylmercury}

All mercury analyses were performed at the USGS Mercury Research Laboratory (MRL) in Middleton, Wis.. Surface water THg was analyzed using cold vapor atomic fluorescence spectrometry (CVAFS) according to a modified version of EPA method 1631 (U.S. Environmental Protection Agency, 1996a; Olson and DeWild, 1999). Surface water $\mathrm{MeHg}$ was quantified by CVAFS following distillation, ethylation and GC separation (DeWild and others, 2002). Water samples were analyzed for four types of mercury: (1) THg in unfiltered water (u-THg), (2) THg in filtered water (f-THg), (3) $\mathrm{MeHg}$ in unfiltered water ( $\mathrm{u}-\mathrm{MeHg}$ ), and (4) $\mathrm{MeHg}$ in filtered water (f-MeHg). Standard procedures for quality assurance (QA) were followed by the MRL, as described in their laboratory QA plan (http://wi.water.usgs.gov/mercury-lab/quality-assurancemanual.html). Method detection limits for THg and MeHg were $0.04 \mathrm{ng} / \mathrm{L}$. Daily detection limits (DDL) at the MRL ranged from 0.01 to $0.03 \mathrm{ng} / \mathrm{L}$ for $\mathrm{THg}$. For $\mathrm{MeHg}$, the DDL ranged from $0.03 \mathrm{ng} / \mathrm{L}$ to $0.12 \mathrm{ng} / \mathrm{L}$. A duplicate sample was collected at site YBWA-2 on October 5, 2005, for analysis of unfiltered $\mathrm{THg}$ and $\mathrm{MeHg}$; relative percent difference (RPD) values were 18 percent and 16 percent, respectively. QA results for 
batch runs that included the project samples were in compliance with data quality objectives for the MRL.

\section{Organic Carbon}

Concentrations of dissolved organic carbon (DOC) were determined at three USGS laboratories: the National Water Quality Laboratory (NWQL) in Denver, Colo.; the National Research Program (NRP) laboratory in Boulder, Colo.; and the California Water Science Center (CWSC) in Sacramento, Calif.. The CWSC laboratory measured DOC concentration by high-temperature catalytic combustion using a Shimadzu TOC5000A total organic carbon analyzer (Bird and others, 2003), whereas the NRP laboratory uses an OI700 Wet-oxidation Total Organic Carbon Analyzer (Aiken, 1992). The NWQL also uses the Wet-oxidation method in conjunction with a Dorhmann carbon analyzer (Brenton and Arnett, 1993). All samples were acidified before analysis to remove dissolved and colloidal carbonates and bicarbonates while minimizing the effects of humic-substance precipitation. The NWQL additionally performed particulate organic carbon (POC) analyses. POC concentrations were determined from the residual material that was collected on $0.3 \mu \mathrm{m}, 25 \mathrm{~cm}$ glass fiber filters used to prepare the DOC samples. The filters were treated with acid to dissolve carbonates and subsequently reacted with potassium persulfate in glass ampoules for 4 hours at $116^{\circ} \mathrm{C}$ to $130^{\circ} \mathrm{C}$. The ampoules were then opened and the resultant carbon dioxide $\left(\mathrm{CO}_{2}\right)$ admitted to an Oceanography International carbon analyzer, which quantified $\mathrm{CO}_{2}$ by infrared spectrometry (Wershaw and others, 1987).

Replicate DOC analyses of two project samples were performed at the CWSC laboratory for analytical precision determination. The replicate analyses produced 2.68percent $(n=8)$ and 3.16-percent $(n=4)$ relative standard deviation for the two samples. Standard duplicate analyses averaged 97-percent recovery of the original values $(n=6)$. An interlaboratory comparison revealed that DOC results from the CWSC and NWQL were similar (average \pm standard deviation, relative percent difference $=7 \pm 6$ percent, $\mathrm{n}=$ 6 ), whereas the NRP laboratory's results exhibited a positive bias of $17 \pm 14$ percent for CWSC and NWQL values above $4 \mathrm{mg} / \mathrm{L}(\mathrm{n}=7)$ and $41 \pm 6$ percent for CWSC and NWQL values below $4 \mathrm{mg} / \mathrm{L}(\mathrm{n}=8)$. Within-laboratory data quality objectives were met for each laboratory. The cause for the observed bias in the NRP laboratory results is unknown, and although this bias did not affect our interpretation of results, we focused on the DOC data from the CWSC laboratory for subsequent data analysis and graphics.

Both CWSC and NRP laboratories also measured DOC absorbance in the ultraviolet and visible spectra, with good analytical agreement between laboratories. Absorption at $254 \mathrm{~nm}$ is reported because of its established use in characterizing the aromaticity of DOC. $\mathrm{UVA}_{254}$ was determined using a Perkin-Elmer spectrophotometer with a 1-cm path length quartz glass sample cuvette (Model UV/Vis Lambda 3B). Samples with measured $\mathrm{UVA}_{254}$ absorbance greater than 1.2 were diluted and reanalyzed. Specific ultraviolet absorbance at 254 nanometers $\left(\mathrm{SUVA}_{254}\right.$, in units of $\left.\mathrm{L} \mathrm{mg}^{-1} \mathrm{~m}^{-1}\right)$ was calculated by normalizing the $\mathrm{UVA}_{254}$ measurement to the respective DOC concentration. Higher SUVA ${ }_{254}$ values indicate a higher proportion of aromatic carbon per unit mass of DOC (Chin and others, 1994; Weishaar and others, 2003). The USGS NRP laboratory further fractionated DOC into hydrophobic (HPOA), hydrophilic (HPIA), and transphylic (TPIA) fractions using Amberlite $\mathrm{XAD}^{\mathrm{TM}}$ resin separation techniques. Separation of the 
DOC into the hydrophobic or hydrophilic fractions provides information about DOC reactivity and structure (Aiken and others, 1992). In cases where DOC concentrations were very low ( $<2.5 \mathrm{mg} / \mathrm{L})$, the smaller fractions (HPIA and TPIA) are difficult to quantify, resulting in poor reproducibility; no value is reported for those fractions in those cases. The relative standard deviation (RSD) of duplicate measures were less than 3 percent for SUVA ( $n=6$ pairs). No duplicate samples were collected within this project for POC or DOC fractionation analyses, but QA results for the batch runs including the project samples were in compliance with data quality objectives for each laboratory.

\section{Major lons and Trace Elements}

Major cations, anions, and trace elements in filtered water were analyzed at the USGS NRP laboratory (Boulder, Colo.) by inductively coupled plasma (ICP) methodsboth atomic emission spectroscopy (AES) and mass spectrometry (MS) were used. Major cations, including calcium (Ca), magnesium $(\mathrm{Mg})$, potassium $(\mathrm{K})$, sodium $(\mathrm{Na})$, and silica ( $\mathrm{Si}$, reported as $\mathrm{SiO}_{2}$ ), were determined by ICP-AES techniques using a Perkin-Elmer Optima 3300DV multichannel emission spectrometer. Iron (Fe) was a trace constituent (concentrations less than $50 \mu \mathrm{g} / \mathrm{L}$ ) in the filtered water samples analyzed for this study; however, it was also determined by ICP-AES techniques. Use of the dualview (radial and axial) optical configuration provided optimal sensitivity for various elements regardless of concentration. A description of the analysis conditions and procedures is reported by Garbarino and Taylor (1996). Details of the operational conditions are described by Mitko and Bebek (1999, 2000). Concentrations were determined for 42 trace elements (Al, As, B, Ba, Bi, Cd, Ce, Co, Cr, Cu, Dy, Er, Eu, Gd, Ho, La, Li, Lu, Mn, Mo, Nd, Ni, Pb, Pr, Rb, Re, S, Sb, Se, Sm, Sr, Tb, Te, Tl, Tm, U, V, W, Y, Yb, Zn, and Zr ) by ICP-MS using a Perkin-Elmer Elan Model 6000 ICP-MS. Aerosols of acidified aqueous samples were introduced into the spectrometer with a conespray pneumatic nebulizer. Multiple internal standards (indium [In], iridium [Ir], and rhodium $[\mathrm{Rh}]$ ), which spanned the mass range, were used to normalize the system for drift. Details of the specific analysis techniques, procedures, and instrumental settings are described by Garbarino and Taylor (1996) and Taylor (2001). Major anions in filtered water (chloride and sulfate) were analyzed by ion chromatography following procedures described by Fishman and Friedman (1989).

All samples collected for analysis of major cations and trace elements were split into replicate bottles, each of which was analyzed in triplicate. The mean values of the triplicate analyses were compared and a standard deviation (SD) was computed. The relative standard deviation (RSD) for each sample was then computed as the SD divided by the average analyte concentration for the two replicates. The RSD was not computed for samples with concentrations less than the reporting limit. For each analyte, the average RSD value was calculated for all the environmental samples in the study. For the major constituents $\mathrm{Ca}, \mathrm{Na}, \mathrm{K}, \mathrm{Na}$, and $\mathrm{SiO}_{2}$, average RSD values were 1.5 percent or less, indicating excellent reproducibility. Average RSD values were less than 2.0 percent for several trace elements (As, B, Ba, Co, Li, Mn, Mo, Ni, Sb, Sr, U, V, W, and Y) and for S, which occurs as the major anion sulfate $\left(\mathrm{SO}_{4}{ }^{2-}\right)$. Most other trace elements $(\mathrm{Al}, \mathrm{Ce}, \mathrm{Cr}$, $\mathrm{Cu}, \mathrm{Dy}, \mathrm{Er}, \mathrm{Gd}$, Ho, La, Lu, Nd, Pb, Pr, Rb, Re, Se, Sm, Tb, Tm, Yb, and Zn) had RSD values between 2 and 15 percent, a range that is generally considered acceptable. Four trace elements $(\mathrm{Cd}, \mathrm{Fe}, \mathrm{Te}$ and $\mathrm{Zr})$ had average RSD values between 15 and 25 percent, and three analytes $(\mathrm{Bi}, \mathrm{Eu}$, and $\mathrm{Tl})$ had average values between 30 and 50 percent. For 
most of these analytes, the concentrations of environmental samples were within an order of magnitude of the reporting limit, a concentration range where a high degree of variability is expected. In the case of Fe, two samples with high RSD values caused the average RSD to be elevated; one of those two samples was near the reporting limit. The average RSD for seven Fe determinations with concentrations in the range of 8 to 14 times the reporting limit $(3 \mu \mathrm{g} / \mathrm{L})$ was 17 percent. No replicate samples were analyzed for major anions. Quality control results for the anion batch runs including the project samples were in compliance with data quality objectives for the USGS NRP laboratory in Boulder, Colo..

\section{Nutrients}

Nutrients were analyzed by the USGS NWQL in Denver, Colorado. The three types of phosphorus $(\mathrm{P})$ analyses included orthophosphate $\left(\mathrm{PO}_{4}^{3-}\right)$ in filtered water and total phosphorus (TP) in both unfiltered and filtered water. Orthophosphate was determined using an automated, colorimetric, phosphomolybdate-blue procedure, with antimony ( $\mathrm{Sb}$ ) added to increase the reduction rate (Patton and Truitt, 1992; Fishman, 1993). Total phosphorus was determined colorimetrically as orthophosphate after Kjeldahl digestion (Patton and Truitt, 1992). The five types of nitrogen (N) analyses included the following forms in filtered water only: (1) nitrite $\left(\mathrm{NO}_{2}^{-}\right),(2)$ nitrite plus nitrate $\left(\mathrm{NO}_{3}{ }^{-}\right)$, and (3) ammonia $\left(\mathrm{NH}_{3}\right)$, plus ammonia and organic nitrogen, which were analyzed in both filtered and unfiltered water. The method used to analyze nitrite was diazotization using sulfanilamide and N-1-naphthylethylenediamine under acidic conditions to form a red compound, the absorbance of which was determined colorimetrically using an automated segmented-flow procedure (Fishman, 1993). The concentration of nitrite plus nitrate was determined by reducing nitrate to nitrite using cadmium metal; the nitrite was then analyzed by diazotization (Fishman, 1993). Ammonia was analyzed using a alicylatehypochlorite method, in the presence of ferricyanide ions, that produces the salicylic acid analog of indophenol blue, which was analyzed colorimetrically using an automated segmented-flow procedure (Fishman, 1993). The concentration of ammonia plus organic nitrogen in unfiltered and filtered samples was determined using the same Kjeldahl digestion as that used for total phosphorus, in which the organic nitrogen is reduced to the ammonium ion, followed by determination of the ammonium ion concentration by the colorimetric salicylatehypochlorite method (Fishman and Friedman, 1989; Patton and Truitt, 1992). No duplicate samples were collected within this project for nutrient analyses, but quality control results for the batch runs including the project samples were in compliance with data quality objectives for the USGS NWQL.

\section{Stable Isotopes of Water and Sulfate}

Stable isotope ratios of oxygen $\left({ }^{18} \mathrm{O} /{ }^{16} \mathrm{O}\right)$ in water were determined using standard methods by the USGS laboratory in Denver, Colo. Oxygen isotope ratios in water, expressed as $\delta^{18} \mathrm{O}_{\mathrm{H} 2 \mathrm{O}}$ in units of \%o (per mill, or parts per thousand) relative to Vienna Standard Mean Ocean Water (VSMOW), were determined by dual inlet mass spectrometery after equilibration with carbon dioxide, a modification of the technique of Epstein and Mayeda (1953). Two working standards calibrated to VSMOW were 
analyzed in duplicate and bracketed the unknowns within each batch run sequence. No duplicate samples were collected within this project for oxygen isotope analysis.

Analytical uncertainty was \pm 0.05 per mill for $\delta^{18} \mathrm{O}_{\mathrm{H} 2 \mathrm{O}}$.

Stable isotope ratios of sulfur $\left({ }^{34} \mathrm{~S} /{ }^{32} \mathrm{~S}\right)$ in aqueous sulfate were also analyzed at the USGS laboratory in Denver, Colo.. Aqueous sulfate was precipitated from filtered water samples at $90^{\circ} \mathrm{C}$ using a barium chloride solution following acidification to $\mathrm{pH} 3-4$ with dilute $\mathrm{HCl}$; the resulting barium sulfate precipitate was filtered $(0.7-\mu \mathrm{m})$, oven dried, and weighed into tin capsules for measurement of $\mathrm{S}$ isotopes by continuous-flow mass spectrometry (Fry and others, 1992; Kester and others, 2001). Sulfur isotopes in aqueous sulfate are expressed as $\delta^{34} \mathrm{~S}_{\mathrm{SO} 4}$ and are reported relative to the Vienna Cañon Diablo Troilite (VCDT). Standards used and accepted values for $\delta^{34} \mathrm{~S}$ were as follows: IAEASO5, 0.49 per mill; NBS127, 21.1 per mill; and IAEA-SO6, -34.05 per mill. Analytical uncertainty was \pm 0.2 per mill for $\delta^{34} \mathrm{~S}_{\mathrm{SO} 4}$. Yield of sulfate during barium sulfate precipitation was 98 to 107 percent of the amount expected based on previous determination of sulfate concentration by ion chromatography. No duplicate samples were collected within this project for sulfur isotope analysis. Quality control results for the batch runs including the project samples were in compliance with data quality objectives for the USGS laboratory in Denver.

\section{Alkalinity}

Alkalinity (a proxy for all dissolved carbonate and bicarbonate species) was analyzed on filtered water samples, usually within 48 hours of collection, by titration with $0.16 \mathrm{~N}$ sulfuric acid $\left(\mathrm{H}_{2} \mathrm{SO}_{4}\right)$, using standard methods (Rounds, 2006). Although no replicate samples were analyzed for alkalinity during this project, the precision of this method is typically \pm 10 percent RPD (relative percent difference) of analytical duplicates.

\section{Suspended Solids Concentration (SSC)}

The USGS laboratory in Marina, Calif., determined suspended solids concentration (SSC) in water samples along with the percentage of fine material $(<0.063$ $\mathrm{mm}$ diameter) in the suspended solids. These quantities were combined to compute the concentration of suspended silt and clay. The terms "suspended solids" and "suspended sediment" are used interchangeably in this report. The procedure used by the USGS Marina laboratory did not include sample oxidization (for example using hydrogen peroxide, as in Poppe and others, 2000) to remove organic matter; therefore, the material that was measured is best described as "suspended solids" rather than by the term "suspended sediment," which is often reserved to refer to residual inorganic material after organic material has been removed. Nevertheless, the results from the Marina lab appear in USGS databases as parameter code 80154, which is identified as "suspended sediment." No duplicate samples were collected within this project for SSC. Batch runs including the project samples were in compliance with data quality objectives for the USGS Marina laboratory. 


\section{Sediment}

All sediment and pore water analyses were conducted at the USGS Laboratory in Menlo Park, Calif..

\section{Total Mercury}

Subsamples for THg in sediment were assayed according to an approved USGS method (Olund and others, 2004), with modifications to the sample digestion. Once thawed, sediment samples (approximately $0.2-0.3 \mathrm{~g}$ wet weight) were initially digested for 24 hours at room temperature in Teflon bombs using a mixture of $2 \mathrm{~mL}$ concentrated nitric acid and $6 \mathrm{~mL}$ of concentrated $\mathrm{HCl}$. The next day, $22 \mathrm{~mL}$ of 5-percent $\mathrm{BrCl}$ was added to each sample, which were then heated to $50^{\circ} \mathrm{C}$ in an oven overnight. Once cooled, a $5 \mathrm{~mL}$ subsample was transferred into a precombusted glass container and held until further analysis. The digestate was analyzed on an Automated Mercury Analyzer (Tekran Model 2600, Tekran, Inc., Canada), according to EPA Method 1631, Revision E (U.S. Environmental Protection Agency, 2002). This standard method is based on the tin reduction of $\mathrm{Hg}$ (II) to gaseous $\mathrm{Hg}^{0}$, trapping $\mathrm{Hg}^{0}$ on gold sand, thermal desorption and quantification of $\mathrm{Hg}^{0}$ via cold-vapor atomic fluorescence spectrometry. Each batch of 10 environmental samples was accompanied by the analysis of the following minimum of Quality Assurance (QA) samples: (a) 1 certified reference material (IAEA-405, estuarine sediment), (b) 1 matrix spike sample, (c) 1 analytical duplicate, and (d) 1 method blank. Calibration standards were prepared from a NIST-certified commercially obtained $\mathrm{HgCl}_{2}$ standard. Quality control acceptance criteria for this assay is detailed in the published methods documents (US Environmental Protection Agency, 2002; Olund and others, 2004). The relative deviation for all samples assayed in duplicate was (average \pm standard error) $13.0 \pm 3.1$ percent $(\mathrm{n}=12$ sample pairs $)$.

\section{Reactive Mercury}

Sediment "reactive" mercury $\left(\mathrm{Hg}(\mathrm{II})_{\mathrm{R}}\right)$ is methodologically defined as the fraction of THg in a sediment sample that has NOT been chemically altered (for example, digested, oxidized, or chemically preserved) and that is readily reduced to elemental $\mathrm{Hg}^{0}$ by an excess of tin chloride $\left(\mathrm{SnCl}_{2}\right)$ over a defined (short) exposure time. This operationally defined parameter was developed as a surrogate measure of the fraction of inorganic $\mathrm{Hg}$ (II) that is most likely available to $\mathrm{Hg}$ (II)-methylating bacteria responsible for $\mathrm{MeHg}$ production. Upon thawing, subsamples collected and frozen in the field for $\mathrm{Hg}(\mathrm{II})_{\mathrm{R}}$ were assayed as previous described (Marvin-DiPasquale and Cox, 2007). The relative deviation for all samples assayed in duplicate was (average \pm standard error) $36.8 \pm 9.6 \%$ ( $\mathrm{n}=6$ sample pairs).

\section{Methylmercury}

Upon thawing, sediment samples collected and frozen in the field for $\mathrm{MeHg}$ analysis were first subsampled (ca. $0.5 \mathrm{~g}$ wet weight) into plastic centrifuge tubes and extracted with $2 \mathrm{M}$ sulfuric acid $(10 \mathrm{~mL})$ overnight while shaking $(200 \mathrm{rpm})$ at $60^{\circ} \mathrm{C}$. Samples were then centrifuged and a $4 \mathrm{~mL}$ subsample of the supernatant was transferred 
into a Teflon distillation vessel containing an aqueous solution $(6 \mathrm{ml})$ of $0.1 \mathrm{M}$ sulfuric acid and 1-percent $\mathrm{KCl}$. Distillation was conducted at $145^{\circ} \mathrm{C}$ until approximately 80 percent of the solution was remaining and then transferred to a Teflon collection vessel. A 2-5 mL aliquot of the distillate was subsampled into a trace-metal-clean glass I-Chem vial. The vial was nearly filled with DI water, the $\mathrm{pH}$ was adjusted to 4.9 using acetate buffer, and the ethylated agent (sodium tetraethyl borate) was added. The vial was then topped off with DI water, capped with a Teflon septa screwtop cap, and shaken well. $\mathrm{MeHg}$ was thus converted, within the vial, to volatile methyl-ethyl-mercury, which was subsequently analyzed on an automated $\mathrm{MeHg}$ analysis system (Brooks Rand Labs, Seattle Wash.) using cold-vapor atomic fluorescence spectrometry (CVAFS) detection. Each batch of environmental samples was accompanied with analysis of the following minimum of Quality Assurance (QA) samples: (a) 1 certified reference material (IAEA405, estuarine sediment), (b) 1 matrix spike sample, (c) 1 analytical duplicate, and (d) 1 method blank. Calibration standards were prepared from crystalline $\mathrm{MeHgCl}$ and compared to a separate commercial $\mathrm{MeHg}$ standard solution. The relative deviation for all samples assayed in duplicate was (average \pm standard error) $13.4 \pm 6.9$ percent $(n=4$ sample pairs).

\section{Bulk Density, Percent Dry Weight, Porosity, and Organic Content}

Sediment bulk density, dry weight, porosity, and organic content were assayed (in the order listed) from a single sediment sample. An exact volume $\left(3.0 \mathrm{~cm}^{3}\right)$ of wet sediment was removed from the sample vial using a plastic syringe that had the needle end cut off of the syringe barrel. This subsample was transferred into a small crucible and weighed. Sediment bulk density $\left(\mathrm{g} / \mathrm{cm}^{3}\right)$ was then calculated as the weight:volume ratio.

Sediment dry weight and porosity were measured using standard drying techniques (American Public Health Association, 1981a). The crucible containing the wet sediment was placed in an oven overnight at $105^{\circ} \mathrm{C}$. The next day, the sample was placed in a desiccator to cool, and then reweighed. The sediment percent dry weight was calculated as [dry wt./wet wt. x 100]. Sediment porosity (mL pore water per $\mathrm{cm}^{3}$ of wet sediment) was calculated as the volume of water lost upon drying divided by the original sediment wet volume. The relative deviation for all samples assayed in duplicate was (average \pm standard error) $1.6 \pm 0.4$ percent for sediment dry weight, $1.5 \pm 0.3$ percent for bulk density, and $1.7 \pm 0.5$ percent for porosity ( $n=13$ sample pairs for each parameter).

Organic content was assessed via the Loss on Ignition (LOI) standard assay (American Public Health Association, 1981b).The crucible containing the oven-dried sediment was placed in a combustion oven at $500{ }^{\circ} \mathrm{C}$ for four hours. This completely burns off organic constituents, leaving only mineral material. After cooling and reweighing, the percent weight loss was calculated. The relative deviation for all samples assayed in duplicate was (average \pm standard error) $7.0 \pm 1.8$ percent $(n=13$ sample pairs).

\section{Acid Volatile Sulfur}

Whole-sediment acid volatile sulfur (AVS) was quantified using a modified acid distillation approach (Zhabina and Volkov, 1978). Upon partial thawing, the contents of the serum vial (sediment preserved with 10-percent zinc-acetate, as described above) 
were fully transferred to a 3-neck distillation flask while continuously purging the flask with $\mathrm{N}_{2}$ gas. An acidic solution of titanium chloride $\left(0.35 \mathrm{M} \mathrm{TiCl}_{2} / 8.4 \mathrm{M} \mathrm{HCl}\right)$ was then added $(20 \mathrm{~mL})$ to the flask through an injection port. The titanium is used to retard the oxidation of sulfide during the distillation process (Albert, 1984). The acid-sediment slurry was then purged for 45 minutes with $\mathrm{N}_{2}$ gas (flow rate $135 \mathrm{~mL} / \mathrm{min}$ ) while stirring with a magnetic stir bar, and without heating. The liberated $\mathrm{H}_{2} \mathrm{~S}$ gas was trapped as $\mathrm{ZnS}$ precipitate in a $10-\mathrm{mL}$ solution of 10 -percent $(\mathrm{w} / \mathrm{v})$ zinc acetate containing 1 drop of antifoam agent (JT Baker antifoam B silicone Emulsion). The ZnS precipitate solution was subsequently vortexed to break up any large particulates, subsampled in duplicate (0.01-1.0 mL), and quantified by colorimetric analysis (Cline, 1969). A concentrated ZnS standard solution was prepared by combining a known weight of solid $\mathrm{Na}_{2} \mathrm{~S}$ crystal in anoxic 10-percent zinc acetate. A serial dilution of this standard $\mathrm{ZnS}$ primary stock was used to prepare a calibration curve for the $S^{2-}$ colorimetric assay. The AVS concentration in the original sediment sample was back-calculated based upon the determination of total $\mathrm{S}^{2-}$ in the $\mathrm{ZnS}$ subsample and the original wet weight of the acid-distilled sediment. Quality assurance consisted of running method blanks, duplicate colorimetric analyses from each $\mathrm{ZnS}$ trap, and occasional matrix spike recovery tests ( $\mathrm{ZnS}$ standard solution added to the distillation flask). No certified reference material is commercially available for the AVS assay. The average daily detection limit for this assay was approximately 1 $\mathrm{nmol} / \mathrm{mL}$ at the level of the colorimetric analysis. The relative deviation for all samples assayed in duplicate was (average \pm standard error) $25.1 \pm 6.1$ percent $(n=11$ sample pairs).

\section{Iron Speciation}

\section{Acid Extractable Ferrous Iron}

Whole-sediment acid extractable ferrous iron (Fe(II) $)_{\mathrm{AE}}$ ) was quantified by weak acid extraction followed by spectrophotometric determination using FerroZine ${ }^{\circledR}$ (Lovley and Phillips, 1986). Upon thawing and under anaerobic conditions, $1.00 \pm 0.05 \mathrm{~g}$ of sediment was sampled (in duplicate) and transferred into a 15-mL plastic centrifuge tube, to which $10 \mathrm{~mL}$ of $0.5 \mathrm{M} \mathrm{HCl}$ was immediately added. The centrifuge tubes were vortexed until a homogeneous slurry was achieved, then placed on a shaker table (200 $\mathrm{rpm})$ in the dark for 1 hour. After centrifugation, $0.1 \mathrm{~mL}$ of the resulting supernatant was subsampled into a test tube containing $5.0 \mathrm{~mL}$ of $1.0 \mathrm{~g} / \mathrm{L}$ FerroZine ${ }^{\circledR}$ reagent $\left(4,4^{\prime}-(3-(2-\right.$ pyridyl)-1,2,4-triazine-5,6-diyl)bisbenzenesulfonic acid, disodium salt; prepared in 50 $\mathrm{mM}$ HEPES buffer and adjusted to $\mathrm{pH}=4$ ). Absorbance was measured on a spectrophotometer at a wavelength of $562 \mathrm{~nm}$.

A Fe $(\mathrm{SO})_{4}$ standard solution series was prepared in $0.25 \mathrm{M}$ hydroxylamine- $\mathrm{HCl}$ and used to prepare a calibration curve for the FerroZine ${ }^{\circledR}$ colorimetric assay. The $\mathrm{Fe}(\mathrm{II})_{\mathrm{AE}}$ concentration in the original sediment sample was back-calculated based upon the determination of total Fe(II) in the subsample and the original wet weight of the acidextracted sediment. Quality assurance consisted of running method blanks and duplicate analyses of each sediment sample. No certified reference material is commercially available for the $\mathrm{Fe}(\mathrm{II})_{\mathrm{AE}}$ assay. The average daily detection limit for this assay was approximately $0.02 \mu \mathrm{g} / \mathrm{mL}$ at the level of the spectrophotometric analysis, and $0.01 \mathrm{mg} / \mathrm{g}$ 
wet sediment, assayed as described. The relative deviation for all samples assayed in duplicate was (average \pm standard error) $3.9 \pm 1.0 \%(\mathrm{n}=10$ sample pairs).

Amorphous Ferric Iron

Whole-sediment amorphous (poorly crystalline) ferric iron $\left(\mathrm{Fe}(\mathrm{III})_{\mathrm{a}}\right)$ has been shown to be the form of $\mathrm{Fe}$ (III) that is most readily available to $\mathrm{Fe}$ (III)-reducing bacteria (Lovley and Phillips, 1987). After the spectrophotometric determination of $\mathrm{Fe}(\mathrm{II})$ in the test tube containing the $0.1 \mathrm{~mL} \mathrm{Fe}(\mathrm{II})_{\mathrm{AE}}$ subsample plus the $5.0 \mathrm{~mL}$ of FerroZine ${ }^{\circledR}$ (as described above), $0.25 \mathrm{~mL}$ of hydroxylamine- $\mathrm{HCl}$ was added to the test tube, which was then vortexed. Hydroxylamine- $\mathrm{HCl}$ reduces any acid extractable $\mathrm{Fe}$ (III) to $\mathrm{Fe}(\mathrm{II})$. After 20 minutes of reaction time, the absorbance at $562 \mathrm{~nm}$ was again measured. This represents the 'total acid extractable iron' fraction $\left(\mathrm{Fe}_{\mathrm{TAE}}\right)$. The $\mathrm{Fe}_{\mathrm{TAE}}$ concentration in the original sediment sample was back-calculated based upon the final Fe(II) concentration in the aqueous subsample and the original wet weight of the acid extracted sediment. $\mathrm{Fe}(\mathrm{III})_{\mathrm{a}}$ was then calculated by difference, according to: $\mathrm{Fe}(\mathrm{III})_{\mathrm{a}}=\mathrm{Fe}_{\mathrm{TAE}}-\mathrm{Fe}(\mathrm{II})_{\mathrm{AE}}$.

The $\mathrm{Fe}(\mathrm{SO})_{4}$ standard calibration curve and approaches to quality assurance were the same as those noted above for the $\mathrm{Fe}(\mathrm{II})_{\mathrm{AE}}$ assay. As part of a parallel project, matrix spike recovery tests were conducted using a $\mathrm{Fe}(\mathrm{III})_{\mathrm{a}}$ solution prepared by neutralizing a 0.4 $\mathrm{M}$ solution of $\mathrm{FeCl}_{3}$ to a $\mathrm{pH}$ of 7 with $\mathrm{NaOH}$ (Lovley and Phillips, 1986), with average matrix spike recoveries of $95 \pm 26$ percent $(\mathrm{N}=15)$. No certified reference material is commercially available for the $\mathrm{Fe}(\mathrm{III})_{\mathrm{a}}$ assay. The method detection limit was similar to that for the $\mathrm{Fe}(\mathrm{II})_{\mathrm{AE}}$ assay. The relative deviation for all samples assayed in duplicate was (average \pm standard error) $23.8 \pm 9.2 \%(\mathrm{n}=10$ sample pairs).

\section{Crystalline Ferric Iron}

Whole-sediment crystalline ferric iron $\left(\mathrm{Fe}(\mathrm{III})_{\mathrm{c}}\right.$ ) was determined by extraction with dithionite-citrate and the spectrophotometric quantification of the resulting $\mathrm{Fe}$ (II) with FerroZine ${ }^{\circledR}$ (Roden and Zachara, 1996). A solution of citrate-acetic acid (0.2M sodium citrate/ $0.35 \mathrm{M}$ glacial acetic acid, $\mathrm{pH}$ adjusted to $4.0 \mathrm{w} / 6 \mathrm{M} \mathrm{HCl}$ ) was initially added $(10 \mathrm{~mL})$ to the centrifuge tubes containing $1.0 \mathrm{~g}$ of thawed sediment. The mixture was vortexed to achieve a homogeneous sediment slurry. Crystalline sodium dithionite was then added $(0.5 \mathrm{~g})$ to each centrifuge tube, which were again vortexed. Sodium dithionite reduces amorphous (poorly crystalline) Fe(III)-silicates and crystalline Feoxide minerals (including goethite $(\alpha \mathrm{FeOOH})$, hematite $\left(\mathrm{Fe}_{2} \mathrm{O}_{3}\right)$, Ferrihydrite $\left(\mathrm{Fe}(\mathrm{OH})_{3}\right)$, lepidocrocite $(\gamma \mathrm{FeOOH})$, and magnetite $\left.\left(\mathrm{Fe}_{3} \mathrm{O}_{4}\right)\right)$ to $\mathrm{Fe}(\mathrm{II})$, but only reduces a fraction of the crystalline Fe-silicate minerals (Eric Roden, written communication, 2004). The centrifuge tubes were placed on a shaker table $(200 \mathrm{rpm})$ in the dark for 1 hour. After centrifugation, $0.01 \mathrm{~mL}$ of the resulting supernatant was subsampled into a test tube containing $5.0 \mathrm{~mL}$ of $1.0 \mathrm{~g} / \mathrm{L}$ FerroZine ${ }^{\circledR}$ reagent. Full color development was achieved after 30 seconds and the absorbance was measured on a spectrophotometer at a wavelength setting of $562 \mathrm{~nm}$. This represents the 'total reactive' iron fraction $\left(\mathrm{Fe}_{\mathrm{TR}}\right)$. The $\mathrm{Fe}_{\mathrm{TR}}$ concentration in the original sediment sample was back-calculated based upon the final $\mathrm{Fe}$ (II) concentration in the aqueous subsample and the original wet weight of the acid extracted sediment. $\mathrm{Fe}(\mathrm{III})_{\mathrm{c}}$ was then calculated by difference, according to: $\mathrm{Fe}(\mathrm{III})_{\mathrm{c}}$ $=\mathrm{Fe}_{\mathrm{TR}}-\mathrm{Fe}_{\mathrm{TAE}}$. 
The $\mathrm{Fe}(\mathrm{SO})_{4}$ standard calibration curve and approaches to quality assurance were the same as those noted above for the $\mathrm{Fe}(\mathrm{II})_{\mathrm{AE}}$ assay. As part of a parallel study, matrix spike recovery tests were conducted with crystalline forms of either goethite (prepared by and obtained from C. Fuller, USGS Menlo Park, Calif.) or magnetite (commercially obtained). Average matrix spike recoveries were $89 \pm 24$ percent $(\mathrm{N}=21)$. No certified reference material is commercially available for the $\mathrm{Fe}(\mathrm{III})_{\mathrm{c}}$ assay. The method detection limit was approximately $0.10 \mathrm{mg} / \mathrm{g}$ wet sediment, as processed above. The relative deviation for all samples assayed in duplicate, and that were above the method detection limit, was (average \pm standard error) $5.5 \pm 1.9$ percent ( $n=6$ sample pairs).

\section{Sediment Pore Water}

\section{Dissolved Organic Carbon and Acetate}

Pore water DOC analysis was assayed using high temperature combustion and IR (infrared) detection on a Total Organic Carbon Analyzer (Model TOC-VCPH, Shimadzu Scientific Instruments, Columbia, Md.). Quality assurance measures include calibration standards, laboratory reagent blank, and filter blanks. The method detection limit was approximately $0.2 \mathrm{mg} \mathrm{C} / \mathrm{L}$. The relative deviation for all samples assayed in duplicate was (average \pm standard error) $6.9 \pm 1.6$ percent ( $\mathrm{n}=6$ sample pairs).

Pore water acetate was measured on an ion chromatograph (Dionex Model DX300, Sunnyvale, Calif.) equipped with an auto-suppressor, an IONPAC AG4A-SC guard column, AS4A-SC analytical column, and mobile phase consisting of $5 \mathrm{mM} \mathrm{Na}_{2} \mathrm{~B}_{4} \mathrm{O}_{7}$. Quality assurance included calibration standards prepared from concentrated commercial stock solutions, laboratory reagent blanks, filter blanks, and analytical duplicates. The method detection limit was approximately $1 \mu \mathrm{mol} / \mathrm{L}$. The relative deviation for all samples assayed in duplicate, and that were above the method detection limit, was (average \pm standard error) $42 \pm 19$ percent $(n=4$ sample pairs).

\section{Ferrous Iron}

The assay for pore water Fe(II) was adapted from previously published methods (Faulkner and others, 1999; Gibbs, 1979). A known amount (for example, 10-500 $\mu \mathrm{L}$ ) of acid-preserved pore water was added to a test tube containing $5.0 \mathrm{~mL}$ FerroZine ${ }^{\circledR}$ reagent. The tube was then vortexed to mix the contents. After full color development (approximately 1 minute), a quartz cell cuvette was rinsed three times with $0.5 \mathrm{~mL}$ of the solution from the test tube and then filled. The absorbance at the $562 \mathrm{~nm}$ wavelength was measured on a Shimadzu Model UV-1601 spectrophotometer (Shimadzu Scientific Instruments, Columbia, Md.). Quality assurance measures include calibration standards, laboratory reagent blank, and duplicate analyses. The detection limit for this assay was approximately $0.02 \mu \mathrm{g} / \mathrm{mL}$ at the level of the spectrophotometric analysis. Assuming a maximum pore water subsample volume of $0.5 \mathrm{~mL}$, the detection limit for the original pore water sample was $0.2 \mathrm{mg} / \mathrm{L}$. The relative deviation for all samples assayed in duplicate, and that were above the method detection limit, was (average \pm standard error) $6.1 \pm 1.8$ percent $(n=5$ sample pairs $)$. 


\section{Sulfate and Chloride}

Pore water sulfate and chloride were measured in accordance with EPA Method 9056A (U.S. Environmental Protection Agency, 2000) using an ion chromatograph (Dionex Model DX-300, Sunnyvale, Calif.) equipped with an auto-suppressor, an IONPAC AG4A-SC guard column, AS4A-SC analytical column, and mobile phase consisting of $1.8 \mathrm{mM} \mathrm{Na}_{2} \mathrm{CO}_{3}$ and $1.7 \mathrm{mM} \mathrm{NaHCO}_{3}$. Quality assurance included calibration standards, laboratory reagent blanks, and analytical duplicates. The relative deviation for all samples assayed in duplicate was (average \pm standard error) $17 \pm 9$ percent $(\mathrm{n}=11$ sample pairs) for sulfate and $1.0 \pm 0.3$ percent $(\mathrm{n}=11$ sample pairs $)$ for chloride.

\section{Sulfide}

Pore water sulfide, preserved in anoxic SAOB (as described above), was assayed using potentiometric quantification via ion selective electrode, as adapted from EPA Method 9215 (U.S. Environmental Protection Agency, 1996b). The silver/sulfide ionspecific electrode (Cole-Parmer part \#: 27502-40) was calibrated prior to use with a standard sulfide solution prepared from crystalline sodium sulfide $\left(\mathrm{Na}_{2} \mathrm{~S}\right)$ in anoxic SAOB . Quality assurance included calibration standards, reagent blanks, and analytical duplicates. The detection limit for this assay was approximately $0.3 \mu \mathrm{mol} / \mathrm{L}$. The relative deviation for all samples assayed in duplicate was (average \pm standard error) 8.0 \pm 2.4 percent ( $\mathrm{n}=9$ sample pairs).

\section{Results and Discussion}

All numeric data results of this study are presented in tables 3-11 as follows: (A) surface water measurements: mercury species (table 3), organics (table 4), nutrients (table 5), major cations and trace elements (table 6), oxygen and sulfur isotopes (table 7), ancillary data (temperature, D.O, pH, SC, alkalinity and SCC; table 8); (B) sediment measurements: mercury species (table 9), ancillary data (dry wt., bulk density, porosity, LOI, AVS, Fe-species, pH, Eh; table 10); and (C) sediment pore water geochemistry (DOC, ferrous iron, sulfate, chloride, acetate and sulfide, table 11). Data plots (figs. 6-20) are presented and described to highlight important aspects of the data set.

The results are described in two parts, those from the Phase I reconnaissance sampling effort, followed by those from the Phase II seasonal sampling effort. This reflects not only the order in which the data were collected, but also the fact that different spatial trends were evident based on the differences in the sites sampled between the two project phases. Specifically, Phase I included the two CCNP sites and the CCSB-1 site, whereas Phase II did not include these three locations, but did include the CCSB permanent (CCSB-2) and seasonal (CCSB-3) wetland sites. Thus, Phase I better reflects a spatial gradient 'snapshot' of waters and sediment upstream of the CCSB, at the outlet of the CCSB, and downstream of the CCSB where waters from Cache Creek mix with Sacramento River drainage in the expansive Yolo Bypass. In contrast, Phase II better reflects the direct comparison of (a) two important regions (CCSB and YBWA) within the lower Sacramento River watershed, known to be impacted by mercury contamination, 
(b) two types of wetland habitat types within those regions (seasonally and permanently flooded wetlands), and (c) two key hydrologic periods, soon after flooding and just prior to draining of the seasonal wetland areas.

\section{Phase I: Field Reconnaissance}

\section{Surface Water}

Phase I sampling revealed high spatial variance in unfiltered surface water $\mathrm{THg}$ concentrations (table 3), with highest concentrations (84 ng/L) at the CCSB-1 site, moderate at the two CCNP locations (11-16 ng/L), and lowest in the two YBWA sites (4.7-5.1 ng/L). In contrast, u-MeHg was highest in the YBWA-2 sites (1.5 ng/L), which had begun being flooded only days prior to sampling. Because very little time had passed to allow the build up of reducing conditions conducive to microbial sulfate reduction and the production of newly formed $\mathrm{MeHg}$, the elevated u-MeHg concentrations in surface water at site YBWA-2 (compared to YBWA-1) may reflect the rapid release of $\mathrm{MeHg}$ formed during or since the last inundation period.

There was a negative correlation between the concentration of $\mathrm{u}-\mathrm{THg}$ and the percentage that was measured as $\mathrm{u}-\mathrm{MeHg}$ along the transect from $\mathrm{CCNP}$ to the YBWA (fig. 6), with percent $\mathrm{u}-\mathrm{MeHg}$ highest at both YBWA sites (15-29 percent of THg), moderate at the two CCNP locations (2.1-3.7 percent of THg), and lowest at CCSB-1 ( 0.2 percent of $\mathrm{THg}$ ). Other surface water trends observed for Phase I include: (a) DOC concentrations (table 4) ranged from $3.2 \mathrm{mg} / \mathrm{L}$ (CCSB-1) to $8.8 \mathrm{mg} / \mathrm{L}$ (YBWA-1); (b) SC (table 8) ranged from $679 \mu \mathrm{S} / \mathrm{cm}$ (CCSB-1) to1,088 $\mu \mathrm{S} / \mathrm{cm}$ (CCNP-1), and (c) pH (table 8) was alkaline in all cases, ranging narrowly from 8.31 (YBWA-2) to 8.57 (CCSB-1).

\section{Sediment and Pore water}

Paralleling the trend observed in overlying water, sediment $\mathrm{Hg}$ speciation ranged widely among the three regions examined during Phase I (table 9), with the CCSB-1 site also exhibiting the highest $\mathrm{THg}$ concentration $(959 \mathrm{ng} / \mathrm{g}$; fig. 7A $)$. In contrast, the pool of sediment $\mathrm{Hg}(\mathrm{III})_{\mathrm{R}}$ was elevated in both YBWA sites $(6.8-7.9 \mathrm{ng} / \mathrm{g})$ compared to the CCNP and CCSB sites (0.3-2.0 ng/g) (fig. 7B), indicating a larger pool of inorganic $\mathrm{Hg}$ (II) available for the $\mathrm{Hg}$ (II)-methylation process in the YBWA, compared to either of the two Cache Creek regions sampled. Sediment MeHg was indeed highest at YBWA-1 $(1.22 \mathrm{ng} / \mathrm{g})$, the permanent wetland, although significantly lower $(0.42 \mathrm{ng} / \mathrm{g})$ at YBWA-2, the seasonal wetland site that had only been flooded for a few days (fig. 7C). This suggests that the elevated surface water MeHg concentrations (noted above) may have sourced from the release of previously formed $\mathrm{MeHg}$ in the sediment following inundation, as opposed to new production. The comparatively high sediment redox value at the YBWA-2 site (+ $187 \mathrm{mV}$, table 10) during Phase I also does not suggest conditions favorable for anaerobic bacteria typically associated with $\mathrm{MeHg}$ production.

A positive correlation was observed between sediment $\mathrm{THg}$ concentration and sediment organic content (fig. 8), a trend that has been shown in other studies (Langston, 1986; He and others, 2007). Two related trends involving sediment $\mathrm{Hg}(\mathrm{II})_{\mathrm{R}}$ were also noted: (a) a strong negative relationship between $\mathrm{Hg}(\mathrm{II})_{\mathrm{R}}$ concentration and sediment 
AVS (fig. 9A) and (b) a positive relationship between the percent $\mathrm{Hg}(\mathrm{II})_{\mathrm{R}}$ (as a percentage of $\mathrm{THg}$ ) and sediment redox (fig. $9 \mathrm{~B}$ ). Similar findings in other studies are less common, as the sediment $\mathrm{Hg}(\mathrm{II})_{\mathrm{R}}$ assay has only recently begun gaining acceptance as a measure of microbially available $\mathrm{Hg}$ (II) (Marvin-DiPasquale and others, 2006, 2009). However, similar relationships have been observed in multiple ecosystem studies conducted by the USGS Menlo Park group (Marvin-DiPaquale and Cox, 2007; Marvin-DiPasquale and others, 2007; Yee and others, 2007; Marvin-DiPasquale, unpublished data). This general trend is thought to reflect the binding of inorganic $\mathrm{Hg}$ (II) to solid-phase reduced-S minerals and the relative increase or decrease in the unbound $\mathrm{Hg}$ (II) fraction (that is, $\left.\mathrm{Hg}(\mathrm{II})_{\mathrm{R}}\right)$ as the pool size of sediment reduced-S compounds decreases or increases, respectively. In the current study, it was the site that was most recently flooded (YBWA2) that was most oxidized (had the highest redox value), and also had the highest AVS concentration, as well as the highest $\mathrm{Hg}(\mathrm{II})_{\mathrm{R}}$ concentration and percent $\mathrm{Hg}(\mathrm{II})_{\mathrm{R}}$. These trends point to the importance of wetting/drying cycles and their impact on sediment geochemical conditions and $\mathrm{Hg}$ speciation.

Sulfur (S) geochemistry can directly affect mercury cycling in two significant ways: (a) pore water sulfate fuels microbial sulfate reduction in anoxic sediment, where sulfate reducing bacteria are the primary microbial group responsible for mediating the $\mathrm{Hg}$ (II)-methylation (MeHg production) reaction (Gilmour and others, 1992), and (b) inorganic $\mathrm{Hg}(\mathrm{II})$ can bind strongly with solid-phase reduced-S compounds, thus affecting the pool size of microbially available $\mathrm{Hg}(\mathrm{II})_{\mathrm{R}}$ (Marvin-DiPasquale and others, 2006, 2007; Yee and others, 2007). Strong spatial trends were noted for S species in sediment and pore water collected as part of Phase I. A three-order-of-magnitude gradient was observed in pore water sulfate concentrations, with the lowest concentrations at two sites in the CCNP (ca. $1 \mu \mathrm{mol} / \mathrm{L})$, followed by CCSB-1 $(113 \mu \mathrm{mol} / \mathrm{L})$, and the highest concentrations were at the two sites in the YBWA $(929-1,011 \mu \mathrm{mol} / \mathrm{L})$ (table 11, fig. $10 A)$. This spans the range of sulfate concentrations from those that have been shown to limit rates of microbial sulfate reduction in freshwater systems $(<30 \mu \mathrm{mol} / \mathrm{L})$ (Lovley and Klug, 1986), to those that are typically considered nonlimiting ( $>1,000 \mu \mathrm{mol} / \mathrm{L})$ (Skyring, 1987). In light of this wide range in sulfate, it is somewhat surprising that pore water sulfide, the end product of microbial sulfate reduction, was very low or below detection at all sites (table 11, fig. 10B). This suggests that any sulfide produced via sulfate reduction either was readily reoxidized or was precipitated as solid phase FeS or $\mathrm{FeS}_{2}$ by $\mathrm{Fe}$ (II) generated by $\mathrm{Fe}$ (III)-reducing bacteria. The potential for this latter process is supported by the high concentrations of solid-phase AVS (largely FeS) in the CCNP and CCSB sites (table 10, fig. 10C). The comparatively low concentrations of AVS in the YBWA sites, coupled with the higher sediment redox conditions $(+145$ to $+187 \mathrm{mV})$, compared to the CCNP and CCSB sites $(+72$ to $+82 \mathrm{mV})$ (table 10), indicates that the YBWA sediments sampled were more oxidized and that the geochemical conditions likely were not favorable to microbial sulfate reduction (an anaerobic microbial process) during Phase I.

Just as sediment $\mathrm{S}$ chemistry can influence $\mathrm{Hg}$ cycling (as described above), sediment Fe chemistry can influence S chemistry (and vice versa). Strong spatial gradients in Fe species were observed in the transect from the CCNP to the YBWA; the YBWA sediment had high concentrations of oxidized Fe(III) (both crystalline and amorphous fraction) relative to the CCNP and CCSB-1 sites (table 10, figs. 11A, 11B). This parallels the other indices noted above (that is, redox and reduced-S) suggesting that the YBWA sites were generally more oxidized than the three upstream sites. The poorly 
crystalline (amorphous) $\mathrm{Fe}(\mathrm{III})_{\mathrm{a}}$ pool is a measure of the fraction of total iron that is most readily available for microbial Fe(III)-reduction (Lovley and Phillips, 1987), with Fe(III) concentration being proportional to the potential for microbial Fe(III)-reduction (Roden and Wetzel, 2002). To this extent, the Fe(III) data suggests that at the time of sampling, the YBWA sites had enhanced 'potential' for microbial Fe(III)-reduction, compared to the other three sites. The newly flooded YBWA-2 seasonal wetland had a significantly lower solid phase $\mathrm{Fe}(\mathrm{II})_{\mathrm{AE}}$ concentration than the nearby YBWA-1 seasonal wetland (table 10, fig. $11 C$ ), suggesting that either rates of microbial Fe(II)-reduction were lower in YBWA-2 or not enough time had passed since this site was reflooded for the pool of $\mathrm{Fe}(\mathrm{II})_{\mathrm{AE}}$ to build up to any appreciable extent. Pore water ferrous iron (Fe(II) $\left.)_{\mathrm{PW}}\right)$ was highest at the CCNP sites (table 11, fig. 11D), which supports the idea that the rates of microbial sulfate reduction are sulfate limited in this region. This results in very little generation of free sulfide, subsequently allowing $\mathrm{Fe}(\mathrm{II})_{\mathrm{PW}}$ to build up, as opposed to being precipitated by sulfide and forming solid phase Fe-S minerals. Thus, although microbial rates of sulfate and iron reduction were not directly measured in this study, useful regional insights into controls on $\mathrm{Hg}$ speciation and cycling were gleaned from the examination of $\mathrm{S}$ and Fe speciation in the sediment solid and pore water phases.

\section{Phase II: Seasonal Field Sampling}

\section{Surface Water}

Surface water collected as part of Phase II revealed a similar regional trend as was observed during Phase I, with YBWA wetlands having higher u-MeHg concentrations (and percent $\mathrm{MeHg}$ ) in unfiltered samples compared to CCSB wetlands (table 3, fig . 12). Furthermore, water collected at the inlet of the YBWA seasonal wetland (site YBWA-3) during late October 2005 had lower u-MeHg concentrations than did water collected from the wetland interior (YBWA-2) (table 3), consistent with $\mathrm{MeHg}$ production within the seasonal wetland area. Concentrations of $\mathrm{MeHg}$ (and percent $\mathrm{MeHg}$ ) in filtered surface water also showed a similar regional trend, with higher levels in the YBWA compared to the CCSB (table 3). In contrast, there was no significant difference in $\mathrm{u}-\mathrm{THg}$ or $\mathrm{p}-\mathrm{THg}$ concentrations between YBWA and CCSB wetlands (all dates, Phase II only). However, average $\mathrm{f}-\mathrm{THg}$ concentration was significantly $(\mathrm{P}<0.05)$ higher in YBWA wetlands $(1.71 \pm 0.27 \mathrm{ng} / \mathrm{L}, \mathrm{n}=4)$ compared to $\mathrm{CCSB}$ wetlands $(0.83 \pm 0.11 \mathrm{ng} / \mathrm{L}, \mathrm{n}=4)$. This trend may be linked to the overall higher concentrations of HPOA (table 4) in the YBWA wetlands $(2.54 \pm 0.27 \mathrm{mg} / \mathrm{L}, \mathrm{n}=4)$, compared to the CCSB wetlands $(0.75 \pm 0.08 \mathrm{mg} / \mathrm{L}, \mathrm{n}=$ 4 ), as this highly aromatic fraction of the DOC pool has been shown to facilitate the partitioning of $\mathrm{THg}$ from the suspended particulate phase into the dissolved phase (Ravichandran, 2004; Waples and others, 2005; Suess, 2006).

Suspended sediment concentration (SSC) was strongly correlated with $\mathrm{u}-\mathrm{THg}$ concentration in surface water, across both regions and wetland types (fig 13A), particularly in the lower concentration range. A single high SSC sample from the CCSB corresponds with an elevated $\mathrm{u}-\mathrm{THg}$ concentration at this site. This may reflect a different source of sediment during high-flow (high SSC) events. Concentrations of mercury in suspended particulates ( $\mathrm{p}-\mathrm{THg}$ ) were calculated using the equation $\mathrm{p}-\mathrm{THg}=(\mathrm{u}-\mathrm{THg}-\mathrm{f}-$ $\mathrm{THg}$ )/SCC (table 3), and ranged from 359 to $589 \mathrm{ng} / \mathrm{g}$ and from 224 to $430 \mathrm{ng} / \mathrm{g}$ in the 
CCSB and YBWA wetland sites, respectively. The YBWA seasonal wetland inlet (YBWA-3) had a three-fold lower p-THg (100 ng/g) than did the permanent wetland itself (YBWA-2; $284 \mathrm{ng} / \mathrm{g}$ ) during October 2005. The relation between SSC and u-MeHg differed between the two regions, with higher $\mathrm{p}-\mathrm{MeHg}$ concentrations in the YBWA (22$49 \mathrm{ng} / \mathrm{g}$ ), compared to the CCSB (5-18 ng/g) (fig. 13B). Because all f-MeHg concentrations were below the analytical detection limit at the CCSB sites (table 3), a more rigorous calculation of particulate $\mathrm{MeHg}(\mathrm{p}-\mathrm{MeHg})$, based on the equation $\mathrm{p}-\mathrm{MeHg}$ $=(\mathrm{u}-\mathrm{MeHg}-\mathrm{f}-\mathrm{MeHg}) / \mathrm{SCC}$, was not possible for the CCSB samples. For the YBWA samples, p-MeHg was calculated (table 3) and ranged from 11 to $40 \mathrm{ng} / \mathrm{g}$, which is somewhat lower than the $22-49 \mathrm{ng} / \mathrm{g}$ range cited above for SCC normalized $\mathrm{u}-\mathrm{MeHg}$ concentrations in the YBWA. Regardless, the regional differences evident in fig. $13 B$ suggest a local source of $\mathrm{MeHg}$ to the water column, in each area. This is supported by the overall positive relationship between $\mathrm{u}-\mathrm{MeHg}$ concentration in surface water and $\mathrm{MeHg}$ concentrations in surface (0-2 cm) sediment during Phase II sampling (fig. 14) and illustrates the importance of sediment as a source of $\mathrm{MeHg}$ to the water column in Sacramento River basin wetlands. A similar positive relationship was not observed in the case of $\mathrm{u}-\mathrm{THg}$ water column concentrations and $\mathrm{THg}$ sediment concentrations.

Filter-passing total mercury (f-THg) in surface water was correlated to a similar extent with both filter-passing total iron (f-Fe) (fig. 15A) and DOC (fig. 15B) concentrations, across all samples collected during Phase II. Spatially, the CCSB sites had lower concentrations of all three constituents (f-THg, f-Fe, and DOC) compared to the YBWA sites. An increase in f-Fe concentration in overlying water may be indicative of either (a) benthic Fe(III)-reducing conditions that produce soluble Fe(II) or (b) the stabilization of colloidal Fe(III) by dissolved organic matter. Redox-driven metal cycling (for example, $\mathrm{Fe}(\mathrm{II})-\mathrm{Fe}(\mathrm{III})$ transformations) has been shown to lead to $\mathrm{THg}$ mobilization in other systems (Regnell and Ewald, 1997; Fleck, 1999; Slowey and Brown, 2007; Canario and others, 2008), and the sediment Fe and S geochemical data (presented above and below) supports the view that the YBWA has a comparatively high potential for microbial Fe(III)-reduction. Alternatively, an increase in some forms of DOC (for example, aromatic HPOA) has been shown to enhance the dissolution of mineral forms of $\mathrm{Hg}$ (Ravichandran, 2004; Waples and others, 2005) and to affect the partitioning of $\mathrm{THg}$ between the dissolved and particulate phases (Barbiarz and others, 2001; Suess, 2006). Because DOC was also moderately correlated with f-Fe (Pearson correlation coefficient $r=0.83$, not shown), it is difficult to separate the relative influences of DOC and f-Fe on mediating the spatial and temporal trends observed for f$\mathrm{THg}$ in the current data set, though both likely played a role to some extent. It is noteworthy that within the YBWA seasonal wetland sampling area, the inlet water (YBWA-3), as measured on October 31, 2005 (just less than one month since initial flooding), had 46 percent lower $\mathrm{THg}$ concentrations, 17 percent lower f-Fe concentrations and only 5 percent lower DOC concentrations, compared to the YBWA-2 site (table 3). In contrast, the drainage water (YBWA-4) measured at the end of the flooding season (May 22, 2006) had THg (table 3), DOC (table 4) and f-Fe (table 6) concentrations much more similar to the YBWA-2 site measured on the same date. Together, these observations suggest within-field generation of dissolved $\mathrm{THg}, \mathrm{Fe}$, and DOC in the YBWA seasonal wetland.

Surface-water nutrient data, collected during Phase II, is presented in table 5. Overall nutrient concentrations ( $\mathrm{N}$ and $\mathrm{P}$ ) tended to be higher at the YBWA than at the CCSB (for example, organic nitrogen (N-org.) plus ammonium $\left(\mathrm{NH}_{4}^{+}\right)$in unfiltered 
water, total-P and $\mathrm{PO}_{4}{ }^{3-}$ in filtered water during October 2005, total-P in unfiltered water). An exception to this was the inorganic forms of nitrogen (nitrate plus nitrite) in filtered water, which were higher at the CCSB compared to the YBWA. There was a seasonal increase in both particulate total-N (table 5) and particulate organic carbon (POC, table 4) at all sites between the first and last Phase II samplings dates in each region, with final concentrations at the end of the study (May 2006) much higher at the YBWA sites and highest at the YBWA seasonal wetland (site YBWA-2). Furthermore, there was a simultaneous significant temporal decrease in filtered total-P and $\mathrm{PO}_{4}^{3-}$, which was also most pronounced in the YBWA sites. These data suggest that the higher nutrient levels in the YBWA (particularly phosphate) during the winter may be leading to more primary production in the form of phytoplankton (as indicated by the particulate total-N and POC data) in the YBWA during the spring, compared to the CCSB. Alternatively, primary production in the YBWA may be dominated by epiphytic algae growing on the stems of vascular plants, which would be responsible for the same temporal depletion of dissolved $\mathrm{P}$ by the spring sampling period. Because phytoplankton (and epiphytic algae) are quite labile (that is, lower $\mathrm{C}: \mathrm{N}$ ) compared to vascular plant material, and because enhanced phytoplankton growth and deposition to the benthos can stimulate microbial processes such as sulfate reduction (Marvin-DiPasquale and Capone, 1998), the apparently enhanced stimulation of algal primary production by nutrients in the YBWA may be one additional factor that accounts for higher $\mathrm{MeHg}$ concentrations in this region, compared to the CCSB.

Data associated with major cations and trace elements (table 6), as well as oxygen isotopes in water $\left(\delta^{18} \mathrm{O}_{\mathrm{H} 2 \mathrm{O}}\right)$ and sulfur isotopes in sulfate $\left(\delta^{34} \mathrm{~S}_{\mathrm{SO} 4}\right)(\underline{\text { table }} 7)$ are presented in their respective tables but not discussed in further detail in the current report. However, this basic geochemical information will be used in conjunction with similar data currently being collected as part of an ongoing study of mercury cycling in the Yolo Bypass as it relates to agricultural practices and wetland management. Specifically, the oxygen isotope data will provide information about evaporation and water sources, while the sulfur isotopes will be used to assess the influence of sulfate from agricultural fertilizers, as well as the influence of sulfate reducing bacteria, on the $\mathrm{Hg}(\mathrm{II})$-methylation process.

\section{Sediment and Pore Water}

In the CCSB, the permanent wetland site (CCSB-2) had a lower sediment $\mathrm{THg}$ concentration than did the corresponding seasonal wetland site (CCSB-3), whereas the reverse was true for the paired permanent and seasonal wetland sites in the YBWA (table 9; fig. 16A). There was no evidence of strong temporal changes in $\mathrm{THg}$ concentration within a given sampling site. At all sites, the percentage of $\mathrm{THg}$ that was $\mathrm{Hg}(\mathrm{II})_{\mathrm{R}}$ was small, with the highest values observed in the YBWA-2 seasonal wetland immediately after flooding (6.3 percent, Phase I), which dropped to 0.1 percent by the end of the flooding season (May 22, 2006) (table 9). Except for the initial flooding of YBWA-2, all other sites had $\mathrm{Hg}(\mathrm{II})_{\mathrm{R}}$ levels consistently below 1 percent of $\mathrm{THg}$ (table 9, fig. 16B). These observations are consistent with measurements of sediment from other ecosystem studies conducted by the USGS Menlo Park research group (Marvin-DiPasquale and others, 2006; Marvin-DiPasquale and Cox, 2007). Sediment MeHg concentrations, and percent $\mathrm{MeHg}$, were generally higher in the YBWA sites compared to the CCSB sites (table 9, figs. 16C, 16D). Because percent $\mathrm{MeHg}$ is often used as a surrogate measure of microbial MeHg production efficiency (Sunderland and others, 2006), the data suggest 
higher rates of microbial $\mathrm{Hg}$ (II)-methylation in the YBWA. This is supported by the generally higher concentration of organic matter in the YBWA (fig. 17), which would tend to drive higher overall rates of microbial activity (for example, microbial $\mathrm{Hg}$ (II)methylation).

Data regarding site-specific temporal trends of sediment $\mathrm{MeHg}$ concentration are limited to two dates for the CCSB sites, where there was a general increase in $\mathrm{MeHg}$ at the permanent wetland site (CCSB-2) and little change at the seasonal wetland site (CCSB-3) during the 106 days between the February 2006 'postflooding'" and May 2006 'end-of-season' sampling dates (Fig. 16C). The temporal data for YBWA are slightly more detailed, as sampling dates include approximately 1-2 days after initial flooding (October 5, 2005), 1 month after initial flooding (October 31, 2005), and towards the end of the flooding season (May 22, 2006). This time sequence is graphically illustrated in fig. 18, with a very sharp increase in both $\mathrm{MeHg}$ concentration and percent $\mathrm{MeHg}$ at the seasonal wetland site (YBWA-2) between the first and second sampling events. This was followed by a decrease in both $\mathrm{MeHg}$ metrics ( $\mathrm{MeHg}$ concentration and percent $\mathrm{MeHg}$ ) by the end of the flooding season. A similar trend was not observed at the nearby permanent wetland (YBWA-1), where both $\mathrm{MeHg}$ concentration and percent $\mathrm{MeHg}$ changed very little among the three sampling dates.

As per Phase I results, an examination of $\mathrm{S}$ and Fe speciation in sediment and pore water provides some insight as to spatial and temporal controls on $\mathrm{Hg}$ cycling during Phase II. Significant observations with respect to S chemistry include: (a) higher concentrations of solid phase AVS and lower concentrations of pore water sulfate in the YBWA sites, compared to the CCSB by May 2006 (figs. 19A, 19B); (b) a significant increase in AVS concentration between early October 2005 (Phase I) and May 2006 in the YBWA wetlands (table 10); (c) a significant (1,000-fold) decrease in pore water sulfate between early October 2005 (Phase I) and May 2006 in the YBWA wetlands (table 11); and (d) only minimal temporal changes in AVS (table 10, fig. 19A), pore water sulfate (table 11, fig. 19B) and pore water sulfide (table 11, fig. 19C) in CCSB sites during Phase II. Taken together, the above temporal and spatial differences with respect to sediment $S$ chemistry suggest that microbial sulfate reduction was quite active in the YBWA during the study period, but by comparison was only minimally active in the CCSB.

The fact that pore water sulfide concentrations remained at low (for example, 3 $\mu \mathrm{M})$ at all sites and times throughout the study (table 11, fig. 19C) suggests that Fe chemistry may play a particularly important role in mediating S chemistry (via Fe-S precipitation reactions), particularly in the YBWA, where microbial sulfate reduction appeared to be very active and large temporal increases in AVS (composed largely of $\mathrm{FeS}$ ) were observed. Significant observations with respect to Fe chemistry include: (a) comparable levels of crystalline Fe(III) among all sites during Phase II (fig. 20A); (b) 23 -fold higher levels of amorphous Fe(III) $)_{\mathrm{a}}$ in the CCSB seasonal wetland, compared to the CCSB permanent wetland (fig. 20B $)$; (c) a significant 25-fold decrease in $\mathrm{Fe}(\mathrm{III})_{\mathrm{a}}$ in the YBWA sites between early October 2005 (Phase I) and May 2006 (table 10); (d) a 3.6-fold increase in $\mathrm{Fe}(\mathrm{II})_{\mathrm{AE}}$ in the YBWA seasonal wetland site (YBWA-2), but no significant increase in the permanent wetland site (YBWA-1) between early October 2005 (Phase I) and May 2006 (table 10); and (e) pore water Fe(II) was below detection

\footnotetext{
${ }^{1} 52$ days after initial flooding of the CCSB on December 23, 2005, as determined from historical USGS gage data at Cache Creek (Station ID: 11452500); online: http://waterdata.usgs.gov/ca/nwis/sw.
} 
in CCSB (both sites and dates), but increased in both YBWA sites from levels below detection in early October 2005 (reconnaissance sample) to 2.6-3.0 mg/L by May 2006 (table 11, fig. 20D). Taken together, these data suggest that (a) both seasonal wetland sites had a greater propensity for microbial Fe(III) reduction than their corresponding permanent wetland counterparts, (b) microbial Fe(III) reduction was most active in the YBWA seasonal wetland (site YBWA-2) during the overall period of study, and (c) seasonal dry-down may be significant for resetting the Fe cycle. By the end of the study (May 2006), much of the potential for Fe(III) reduction had been exhausted at site YBWA-2. At that point, and based upon Fe(III) ${ }_{\mathrm{a}}$ concentrations (table 10, fig. 20B), the potential for $\mathrm{Fe}(\mathrm{III})$ reduction decreased by site in the following order: CCSB-3 ( seasonal) $>$ CCSB-2 (permanent) $>$ YBWA (both sites).

\section{Summary and Conclusions}

Data collected as part of the current study provide a detailed temporal and spatial geochemical snapshot of conditions as they vary in surface water and sediment within and among a suite of permanently and seasonally flooded wetlands in the lower Sacramento River drainage basin. Strong spatial differences were observed, with wetlands associated with the Yolo Bypass Wildlife Area (YBWA) prone to higher concentrations of $\mathrm{MeHg}$ in both sediment and water compared to the Cache Creek Settling Basin (CCSB). Furthermore, the seasonal wetland in YBWA showed a significant increase in sediment $\mathrm{MeHg}$ concentrations approximately 3-4 weeks after initially flooding, followed by a decline to levels comparable to the YBWA permanent wetland by the end of the flooding period. Similar seasonal differences between the two habitat types (seasonal versus permanent wetland) were not as pronounced within the CCSB.

Although the site-specific ancillary geochemical data presented herein help explain the temporal and spatial variations in mercury speciation observed among sites, the two regions examined also vary with respect to depositional environment and management practices, both of which may affect site-specific geochemistry. The CCSB receives freshly deposited, highly worked-over sediments, with mercury originating from natural geologic sources and cinnabar $(\mathrm{HgS})$ mining areas. Inputs to the CCSB are largely controlled by seasonal flooding of Cache Creek as a function of natural variations in wet or dry year precipitation events. As a result, sediments deposited to the CCSB tend to be a mix of fine-grained and courser grained material, mobilized by episodic, often highenergy, flooding. In contrast, the YBWA has established, well vegetated sediments, with managed wetting and drying cycles manipulated to provide bird habitat on seasonally flooded fields. Flooding of the YBWA is controlled by the diversion of Toe drain water (fig. $\underline{3 B}$ ), and by the time this water reached the fields sampled, it would be expected to contain more fine-grained suspended particles and less course material (due to slower water velocities), compared to the CCSB. Furthermore, $\mathrm{Hg}$ inputs to the YBWA reflect a mix of sources, including those from Cache Creek and other coastal cinnabar mining areas, as well as sediment originating from the former hydraulically mined areas in the Sierra Nevada to the west, where elemental $\mathrm{Hg}$ was extensively used.

The current data set provides a foundation for ongoing and future studies focused on determining the key parameters mediating $\mathrm{MeHg}$ production in this geographic area and provides ecosystem managers fundamental geochemical data on which to base 
management strategies aimed at achieving the goal of substantially reducing the amount of $\mathrm{MeHg}$ being produced within, and exported from, these wetland environments. 


\section{Literature Cited}

Ackerman, J.T., Eagles-Smith, C.A., Takekawa, J.Y., Bluso, J.D., and Adelsbach, T.L., 2008, Mercury concentration in blood and feathers of prebreeding Forster's Terns in relation to space use of San Francisco Bay, Califoronia, USA, habitats: Environmental Toxicology and Chemistry, v. 27, p. 897-908.

Aiken, G.R., 1992, Chloride interference in the analysis of dissolved organic carbon by the wet oxidation method: Environmental Science and Technology, v. 26, p. 2435-2439.

Aiken, G.R., McKnight, D.M., Thorn, K.A., and Thurman, E.M., 1992, Isolation of hydrophilic organic acids from water using nonionic macroporous resins: Organic Geochemistry, v. 18, p. 567-573.

Albert, D., 1984, Improved techniques for measurement of sulfate reduction and pyrite formation rates in sediment: Transactions, American Geophysical Union, EOS, v. 45, no. 906.

Alpers, C.N., Hunerlach, M.P., May, J.T., and Hothem, R.L., 2005, Mercury contamination from historical gold mining in California: U.S. Geological Survey, Fact Sheet 2005-3014, 6 p. [http://pubs.usgs.gov/fs/2005/3014/ ]

American Public Health Association, 1981a, Section 209 C: Total nonfiltrable residue dried at $103-105^{\circ} \mathrm{C}$, in Franson, M.A.H., ed., Standard methods for the examination of water and wastewater (15th ed.): Washington, D.C., American Public Health Association, American Water Works Association, Water Pollution Control Federation, p. 94-95.

American Public Health Association, 1981b, Section 209 G: Volatile and fixed matter in nonfilterable residue and in solid and semisolid samples, in Franson, M.A.H., ed., Standard methods for the examination of water and wastewater, 15th Edition: Washington, D.C., American Public Health Association, American Water Works Association, Water Pollution Control Federation, p. 97-99.

Babiarz, C.L., Hurley, J.P., Hoffmann, S.R., Andren, A.W., Shafer, M.M., and Armstrong, D.E., 2001, Partitioning of total mercury and methylmercury to the colloidal phase in freshwaters: Environmental Science and Technology, v. 35, p. 4773-4782.

Bird, S.M., Fram, M.S. and Crepeau, K.L., 2003, Method of analysis by the U.S. Geological Survey California District Sacramento Laboratory - Determination of dissolved organic carbon in water by high temperature catalytic oxidation, method validation, and quality-control practices: U.S. Geological Survey, OpenFile Report 03-366. [http://pubs.usgs.gov/of/2003/ofr03366/text.html]

Brenton, R.W., and Arnett, T.L., 1993, Methods of analysis by the U.S. Geological Survey National Water Quality Laboratory; Determination of dissolved organic carbon by UV-promoted persulfate oxidation and infrared spectrometry: U.S. Geological Survey, Open-File Report 92-480, 12 p. 
Canário, J., Poissant, L., O`Driscoll, N., Ridal, J., Delongchamp, T., Pilote, M., Constant, P., Blais, J., and Lean, D., 2008, Mercury partitioning in surface sediments of the Upper St. Lawrence River (Canada); evidence of the importance of the sulphur chemistry: Water, Air and Soil Pollution, v. 187, p. 219-231.

Chin, Y.-P., Aiken, G., and O'Loughlin, E., 1994, Molecular weight, polydispersity, and spectroscopic properties of aquatic humic substances: Environmental Science and Technology, v. 28, p. 1853-1858.

Cline, J.D., 1969, Spectrophotometric determination of hydrogen sulfide in natural waters: Limnology and Oceanography, v. 14, p. 454-458.

California Regional Water Quality Control Board, Central Valley Region, 2007, Control of methylmercury in the Delta, Draft Basin Plan Amendment Staff Report, Revised Draft Basin Plan Amendment (February 2007): California Regional Water Quality Control Board, Central Valley Region, 32 p., [http://www.waterboards.ca.gov/centralvalley/water_issues/tmdl/central_valley_ projects/delta_hg/workshop_3-16-2007/index.shtml (accessed Sept. 18, 2009)]

Davis, J.A., Yee, D., Collins, J.N., Schwarzbach, S.E., and Luoma, S.N., 2003, Potential for increased mercury accumulation in the estuary food web: San Francisco

Estuary and Watershed Science, v. 1, no. 1/ article 4, p. 1-36. [http://repositories.cdlib.org/jmie/sfews/vol1/iss1/art4/]

Davis, J.A., Greenfield, B.K., Ichikawa, G., and Mark Stephenson, M., 2008, Mercury in sport fish from the Sacramento-San Joaquin Delta region, California, USA: Science of the Total Environment, v. 391, p. 66-75.

De Wild, J.F., Olson, M.L., and Olund, S.D., 2002, Determination of methylmercury by aqueous phase ethylation, followed by gas chromatographic separation with cold vapor atomic fluorescence detection: U.S. Geological Survey, Open-File Report 01-445. [http://pubs.usgs.gov/of/2001/ofr-01-445/]

Domagalski, J.L., 2001, Mercury and methylmercury in water and sediment of the Sacramento River Basin, California: Applied Geochemistry, v. 16, p. 1677-1691.

Domagalski, J.L., 2004, Mercury and methylmercury concentrations and loads in Cache Creek Basin, California, January 2000 through May 2001: U.S. Geological Survey, Scientific Investigations Report 2004-5037, 56 p.

Domagalski, J.L., Slotton, D.G., Alpers, C.N., Suchanek, T.H., Churchill, R., Bloom, N., Ayers, S.M., and Clinkenbeard, J., 2004a, Summary and synthesis of mercury studies in the Cache Creek watershed, California, 2000-01: US Geological Survey, Water-Resources Investigations Report 03-4335, 30 p. [http://pubs.usgs.gov/wri/wri034335/]

Domagalski, J.L., Alpers, C.N., Slotton, D.G., Suchanek, T.H., and Ayers, S.M., 2004b, Mercury and methylmercury concentrations and load in the Cache Creek watershed, California: Science of the Total Environment, v. 327, p. 215-237.

Eagles-Smith, C.A., Ackerman, J.T., De La Cruz, S.E.W., and Takekawa, J.Y., 2009, Mercury bioaccumulation and risk to three waterbird foraging guilds is influenced by foraging ecology and breeding stage: Environmental Pollution, v. 157, p. 1993-2002. 
Epstein, S., and Mayeda, T., 1953, Variation of ${ }^{18} \mathrm{O}$ content of waters from natural sources: Geochimica et Cosmochimica Acta, v. 4, p. 213-224.

Faulkner, S. P., Hintz, P. E., and Ashby, S. L., 1999, Evaluation of colorimetric methods for measuring reduced (ferrous) iron: Water Quality Technical Notes Collection (WQTN PD-02), U.S. Army Engineer Research and Development Center, Vicksburg, Missouri. [www.wes.army.mil/el/elpubs/wqtncont.html]

Fishman, M.J., 1993, Methods of analysis by the U.S. Geological Survey National Water Quality Laboratory; determination of inorganic and organic constituents in water and fluvial sediments: U.S. Geological Survey, Open-File Report 93-125, 217 p.

Fishman, M.J., and Friedman, L.C., eds., 1989, Methods of determination of inorganic substances in water and fluvial sediments: U.S. Geological Survey, Techniques of Water-Resources Investigations, Book 5, Chapt. A-1, 545 p.

Fleck, J.A., 1999, Mercury transport through northern forested watersheds; dissolved and particulate pathways: St. Paul, Minnesota, University of Minnesota, M.S. Thesis.

Foe, C., 2003, Mercury mass balance for the freshwater Sacramento-San Joaquin BayDelta Estuary (TASK 1A); Final report to CALFED: Central Valley Regional Water Quality Control Board, 35 p., [http://loer.tamug.edu/calfed/FinalReports.htm]

Fry, B.N., Brand, W., Mersch, F.J., Tholke, K., and Garritt, R., 1992, Automated-analysis system for coupled delta-C-13 and delta-N-15 measurements: Analytical Chemistry, v. 64, p. 288-291.

Garbarino, J.R., and Taylor, H.E., 1996, Inductively coupled plasma-mass spectrometric method for the determination of dissolved trace elements in natural water: U.S. Geological Survey, Open-File Report 94-358, 88 p.

Gibbs, M.M., 1979, A simple method for the rapid determination of iron in natural waters: Water Research. v. 13, p. 295-297.

Gilmour, C.C., Henry, E.A., and Mitchell, R., 1992, Sulfate stimulation of mercury methylation in freshwater sediments: Environmental Science and Technology, v. 26, p. 2281-2287.

He, T., Lu, J., Yang, F., and Feng, X., 2007, Horizontal and vertical variability of mercury species in pore water and sediments in small lakes in Ontario: Science of the Total Environment, v. 386, p. 53-64.

Kester, C.L., Rye, R.O., Johnson, C.A., Schwartz, C.C., and Holmes, C.W., 2001, Online sulfur isotope analysis of organic matter by direct combustion; preliminary results and potential applications: Isotopes in Environmental and Health Studies. v. 37, p. 53-65. 
Krabbenhoft, D.P., Wienter, J.G., Brumbaugh, W.G., Olson, M.L., DeWild, J.F., and Sabin, T.J., 1999, A national pilot study of mercury contamination of aquatic ecosystems along multiple gradients, in Morganwalp, D.W., and Buxton, H.T., eds., U.S. Geological Survey Toxic Substances Hydrology Program--Proceedings of the Technical Meeting Charleston South Carolina March 8-12,1999--Volume 2 of 3--Contamination of Hydrologic Systems and Related Ecosystems: U.S. Geological Survey Water-Resources Investigation Report 99-4018B. [http://toxics.usgs.gov/pubs/wri99-4018/Volume2/sectionB/2301_Krabbenhoft/]

Langston, W.J., 1986, Metals in sediments and benthic organisms in the Mersey estuary: Estuarine, Coastal and Shelf Science, v. 23, p. 239-261.

Lovley D.R., and Klug, M.J., 1986, Model for the distribution of sulfate reduction and methanogenesis in freshwater sediments: Geochimica et Cosmochimica Acta, v. 50, p. 11-18.

Lovley D.R., and Phillips E.J.P., 1986, Organic matter mineralization with reduction of ferric iron in anaerobic sediments: Applied and Environmental Microbiology, v. 51, p. 683-689.

Lovley, D.R., and Phillips, E.J.P., 1987, Rapid Assay for microbially reducible ferric iron in aquatic sediments: Applied and Environmental Microbiology, v. 53, p. 15361540 .

Marvin-DiPasquale, M.C., and Capone, D.G., 1998, Benthic sulfate reduction along the Chesapeake Bay central channel. I. Spatial trends and controls: Marine Ecology Progress Series, v. 168, p. 213-228.

Marvin-DiPasquale, M., and Cox, M.H., 2007, Legacy mercury in Alviso Slough, South San Francisco Bay, California; concentration, speciation and mobility: U.S. Geological Survey Open-File Report 2007-1240, 98 p., [http://pubs.usgs.gov/of/2007/1240/]

Marvin-DiPasquale, M., Agee, J., Bouse, R., and Jaffe, B., 2003, Microbial cycling of mercury in contaminated pelagic and wetland sediments of San Pablo Bay, California: Environmental Geology, v. 43, p. 260-267.

Marvin-DiPasquale, M., Hall, B.D., Flanders, J.R., Ladizinski, N., Agee, J.L., Kieu, L.H., and Windham-Myer, L., 2006, Ecosystem investigations of benthic methylmercury production; a tin-reduction approach for assessing the inorganic mercury pool available for methylation, in Mercury 2006 Abstracts Book: Eighth International Conference on Mercury as a Global Pollutant, Madison, Wisconsin, August 6-11, 2006.

Marvin-DiPasquale, M., Stewart, A.R., Fisher, N.S., Pickhardt, P., Mason, R.P., Heyes, A., and Windham-Myers, L., 2007, Evaluation of mercury transformations and trophic transfer in the San Francisco Bay/Delta; Identifying Critical Processes for the Ecosystem Restoration Program: Final Report for Project \# ERP-02-P40. Submitted to the California Bay Delta Authority (CBDA), $40 \mathrm{p}$. 
Marvin-DiPasquale, M., Lutz, M.A., Brigham, M.E., Krabbenhoft, D.P., Aiken, G.R., Orem, W.H., and Hall, B.D., 2009, Mercury cycling in stream ecosystems; 2. Benthic methylmercury production and bed sediment-pore water partitioning: Environmental Science and Technology, v. 43, p. 2726-2732.

Mitko, K., and Bebek, M., 1999, ICP-OES determination of trace elements in salinated water: Atomic Spectroscopy , v. 20, p. 217-223.

Mitko, K., and Bebek, M., 2000, Determination of major elements in saline water samples using a dual-view ICP-OES: Atomic Spectroscopy, v. 21, p. 77-85.

Olson, M.L., and DeWild, J.F., 1999, Techniques for the collection and species-specific analysis of low levels of mercury in water, sediment, and biota: U.S. Geological Survey, Water Resources Investigations Report 99-4018-B, 11 p.

Olund, S.D., DeWild, J.F., Olson, M.L., and Tate, M.T., 2004, Methods for the preparation and analysis of solids and suspended solids for total mercury. Chapter 8 of Book 5, Laboratory Analysis; Section A, Water Analysis: U.S. Geological Survey, Techniques and Methods Report 5 A-8, 8p.

Patton, C.J., and Truitt, E.P., 1992, Methods of analysis by the U.S. Geological Survey National Water Quality Laboratory-Determination of total phosphorus by a Kjeldahl digestion method and an automated colorimetric finish that includes dialysis: U.S. Geological Survey, Open-File Report 92-146, 39 p.

Poppe, L.J., Eliason, A.H., Fredericks, J.J., Rendigs, R.R., Blackwood, D., and Polloni, C.F., 2000, Chapter 1. Grain-size analysis of marine sediments; methodology and data processing, in USGS east-coast sediment analysis; procedures, database, and georeferenced displays: U.S. Geological Survey, Open-File Report 00-358 [http://pubs.usgs.gov/of/2000/of00-358/text/chapter1.htm].

Ravichandran, M., 2004, Interactions between mercury and dissolved organic matter--a review: Chemosphere, v. 55, p. 319-331.

Regnell, O., and Ewald, G., 1997, Factors controlling temporal variation in methyl mercury levels in sediment and water in a seasonally stratified lake: Limnology and Oceanography, v. 42, p. 1784-1795.

Roden, E.E., and Wetzel, R.G., 2002, Kinetics of microbial Fe(III) oxide reduction in freshwater wetland sediments: Limnology and Oceanography, v. 47, p. 198-211.

Roden, E.E., and Zachara, J.M., 1996, Microbial reduction of crystalline iron(III) oxides; influence of oxide surface area and potential for cell growth: Environmental Science and Technology, v. 30, p. 1618-1628.

Rounds, S.A., 2006, Alkalinity and acid neutralizing capacity (version 3.0): U.S. Geological Survey, Techniques of Water-Resources Investigations, book 9, chap. A6, section 6.6, [http://water.usgs.gov/owq/FieldManual/Chapter6/section6.6/]

Schemel, L.E., and Cox, M.H., 2007, Floodwater chemistry in the Yolo Bypass, during winter and spring 1998. U.S. Geological Survey Open-File Report 2007-1025, 13 p. [http://pubs.usgs.gov/of/2007/1025/] 
Schemel, L.E., Cox, M.H., Hager, S.W., and Sommer, T.R., 2002, Hydrology and chemistry of floodwaters in the Yolo Bypass, Sacramento River system, California, during 2000: U.S. Geological Survey, Water Resources Investigations Report 02-4202.

Schemel, L.E., Sommer, T.R., Müller-Solger, A.B., and Harrell, W.C., 2004, Hydrologic variability, water chemistry, and phytoplankton biomass in a large floodplain of the Sacramento River, CA, U.S.A.: Hydrobiologia , v. 513, p.129-139.

Schwarzbach, S.E., Suchanek, T.H., Heinz, G.H., Ackerman, J.T., Eagles-Smith, C.A., Adelsbach, T.L., Takekawa, J.Y., Miles, A.K., Hoffman, D.J., Wainwright-De La Cruz, S.E., Spring, S.E., Ricca, M.A., and Maurer, T.C., 2005, Mercury in birds of the San Francisco Bay-Delta; trophic pathways, bioaccumulation and ecotoxicological risk to avian reproduction. 2005 Annual Report submitted to the California Bay Delta Authority: U. S. Geological Survey, Western Ecological Research Center, and U. S. Fish and Wildlife Service, Environmental Contaminants Division, 17 p., [https://nrmsecure.dfg.ca.gov/FileHandler.ashx?DocumentVersionID=10607 (accessed Sept. 18, 20009)]

Shelton, L.R., 1994, Field guide for collecting and processing stream-water samples for the National Water-Quality Assessment Program: U.S. Geological Survey, OpenFile Report 94-455, 42 p.

Slotton, D.G., Suchanek, T.H., and Ayers, S.M., 2000, Delta wetlands restoration and the mercury question: Interagency Ecological Program Newsletter, v. 13, no. 4, p. 40-50.

Slotton, D.G., Ayers, S.M., Suchanek, T.H., Weyand, R.D., Liston, A.M., Asher, C., Nelson, D.C., and Johnson, B., 2002, The effects of wetland restoration on the production and bioaccumulation of methylmercury in the Sacramento-San Joaquin Delta, California: CALFED Bay-Delta Agency/UC Davis, 49 p.

Slotton, D.G., Ayers, S.M., Suchanek, T.H., Weyland, R.D., and Liston, A.M., 2004, Mercury bioaccumulation and trophic transfer in the Cache Creek Watershed, California, in relation to diverse aqueous mercury exposure conditions: Final Report to CALFED, 74 p. [http://loer.tamug.edu/calfed/FinalReports.htm]

Skyring, G.W., 1987, Sulfate reduction in coastal ecosystems: Geomicrobiology Journal, v. 5, p. 295-374.

Slowey, A.J., and Brown Jr., G.E., 2007, Transformations of mercury, iron, and sulfur during the reductive dissolution of iron oxyhydroxide by sulfide: Geochimica et Cosmochimica Acta, v. 71, p. 877-894.

Sommer, T., Harrell, B., Nobriga, M., Brown, R., Moyle, P.B., Kimmerer, W., and Schemel, L., 2001, California's Yolo Bypass; evidence that flood control can be compatible with fisheries, wetlands, wildlife and agriculture: Fisheries, v. 26, p. 6-16. 
Stephenson, M., Foe, C., Gill, G.A., and Coale, K.H., 2008, Transport, cycling, and fate of mercury and monomethyl mercury in the San Francisco Delta and tributaries; an integrated mass balance assessment approach: Final Report to CALFED, [http://mercury.mlml.calstate.edu/reports/reports/]

Suchanek, T.H., Slotton, D.G., Nelson, D.C., Ayers, Shaun M., Asher, C., Weyand, R.D., Liston, A.M., and Eagles-Smith, C., 2002, Mercury loading and source bioavailability from the upper Cache Creek mining districts: Final report to CALFED, 74 p. [http://loer.tamug.edu/calfed/FinalReports.htm]

Suess, E., 2006, Mercury distribution between particulate and dissolved states in wetlands in California, USA: Freiberg, Germany, University of Freiberg, Masters Thesis, $155 \mathrm{p}$.

Sunderland, E.M., Gobas, F.A.P.C., Branfireun, B.A., and Heyes, A., 2006, Environmental controls on the speciation and distribution of mercury in coastal sediments: Marine Chemistry, v. 102, p. 111-123.

Taylor, H.E., 2001, Inductively coupled plasma-mass spectrometry-practices and techniques: San Diego, Calif., Academic Press, 294 p.

U.S. Environmental Protection Agency, 1996a, Draft method 1631-mercury in water by oxidation, purge and trap, and cold vapor atomic fluorescence spectrometry: U.S. Environmental Protection Agency, Report \# 821-R-96-012, Office of Water, 32 p.

U.S. Environmental Protection Agency, 1996b, Method 9215 - potentiometric determination of sulfide in aqueous samples and distillates with ion-selective electrode: U.S. Environmental Protection Agency, Washington D.C., December 1996. [http://www.epa.gov/waste/hazard/testmethods/sw846/pdfs/9215.pdf]

U.S. Environmental Protection Agency, 2000, EPA Method 9056A Rev. 1.0 determination of inorganic anions by ion chromatography: U.S. Environmental Protection Agency, 18 p. [http://www.epa.gov/waste/hazard/testmethods/sw846/pdfs/9056a.pdf]

U.S. Environmental Protection Agency, 2002, Method 1631, Revision E-mercury in water by oxidation, purge and trap, and cold vapor atomic fluorescence spectrometry: U.S. Environmental Protection Agency, Office of Water, EPA-821R-02-019, 36 p.

Waples, J.S., Nagy, K.L., Aiken, G.R., and Ryan, J.N., 2005, Dissolution of cinnabar $(\mathrm{HgS})$ in the presence of natural organic matter: Geochemica et Cosmochemica Acta, v. 69, p. 1575-1588.

Weishaar, J.L., Aiken, G.R., Bergamaschi, B.A., Fram, M.S., and Fujii, R., 2003, Evaluation of specific ultraviolet absorbance as an indicator of the chemical composition and reactivity of dissolved organic carbon: Environmental Science and Technology, v. 37, p. 4702-4708.

Wershaw, R.L., Fishman, M.J., Grabbe, R.R., and Lowe, L.E., 1987, Methods for the determination of organic substances in water and fluvial sediments: U.S.

Geological Survey, Techniques of Water-Resources Investigations, book 5, chap. A3, 80 p. 
Wiener, J.G., Gilmour, C.C., and Krabbenhoft, D.P., 2003, Mercury strategy for the BayDelta Ecosystem; a unifying framework for science, adaptive management, and ecological restoration: Final Report to the California Bay Delta Authority, 59 p.. [http://calwater.ca.gov/science/pdf/MercuryStrategyFinalReport.pdf]

Yee, D., Collins, J., Grenier, L., Takekawa, J., Tsoa-Melcer, D., Woo., I., Schwarzbach, S., Marvin-DiPasquale, M., Windham, L., Krabbenhoft, D., Olund, S., and Evens, J., 2007, Mercury and methylmercury processes in North San Francisco Bay tidal wetland ecosystems: CALFED ERP-02D-P64 Annual Project Report (April 2007), submitted to California Bay-Delta Authority (CBDA), 23 p.

Zhabina, N., and Volkov, I., 1978, A method of determination of various sulfur compounds in sea sediment and rocks, in Krumbein, W.E., ed., Environmental Biogeochemistry and Geomicrobiology (Vol. 3): Ann Arbor, Ann Arbor Sci. Publ., p. 735-746.

Zillioux, E.J., Porcella, D.B., and Benoit, J.M., 1993, Mercury cycling and effects in freshwater wetland ecosystems: Environmental Toxicology and Chemistry, v. 12, p. 2245-2264. 


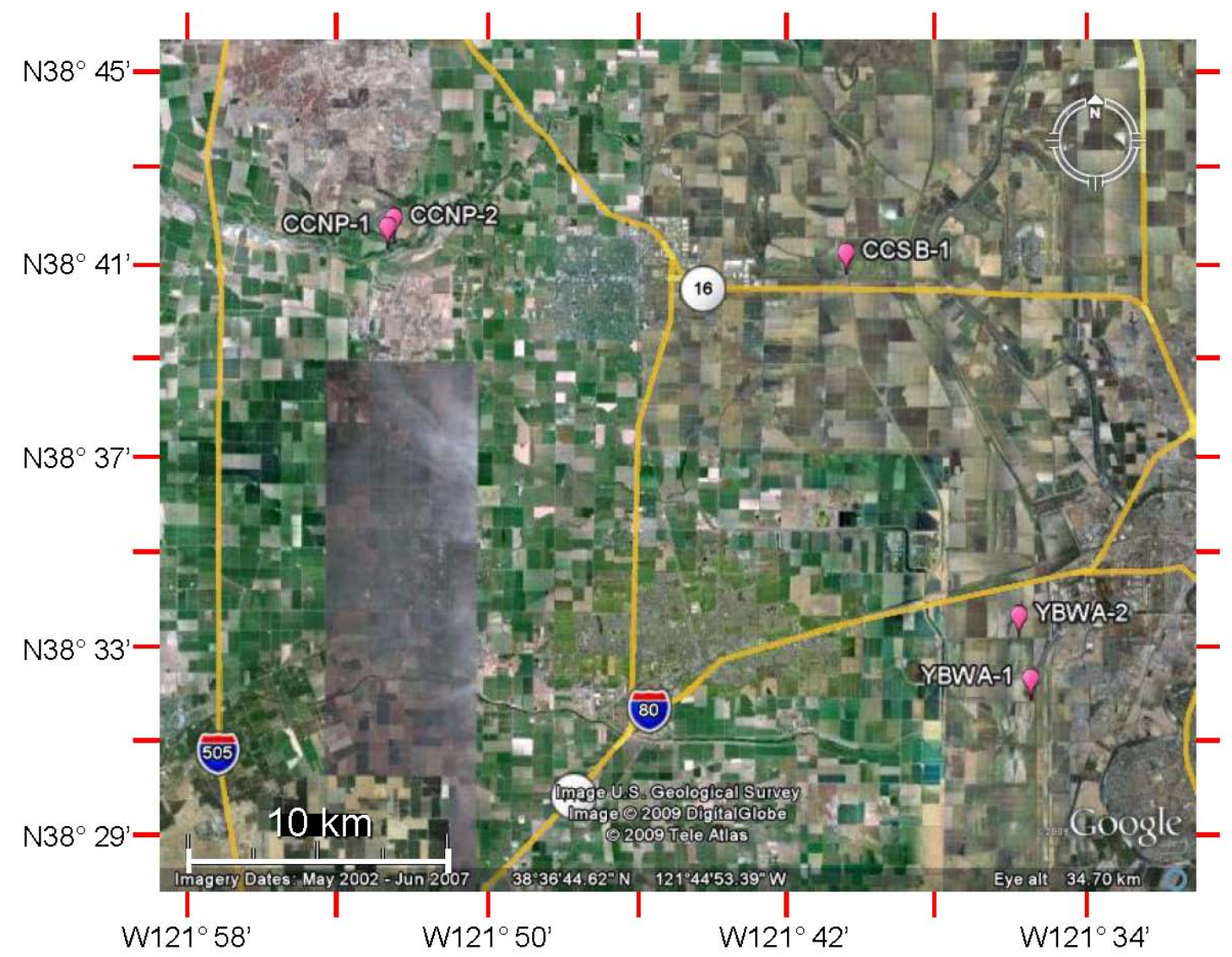

Figure 1. Map of sites sampled during study Phase I (0ctober 5, 2005) within the Cache Creek Nature Preserve (CCNP), Cache Creek Settling Basin (CCSB) and the Yolo Bypass Wildlife Area (YBWA), Yolo County, California.

Base map created in Google Earth. [km, kilometers] 

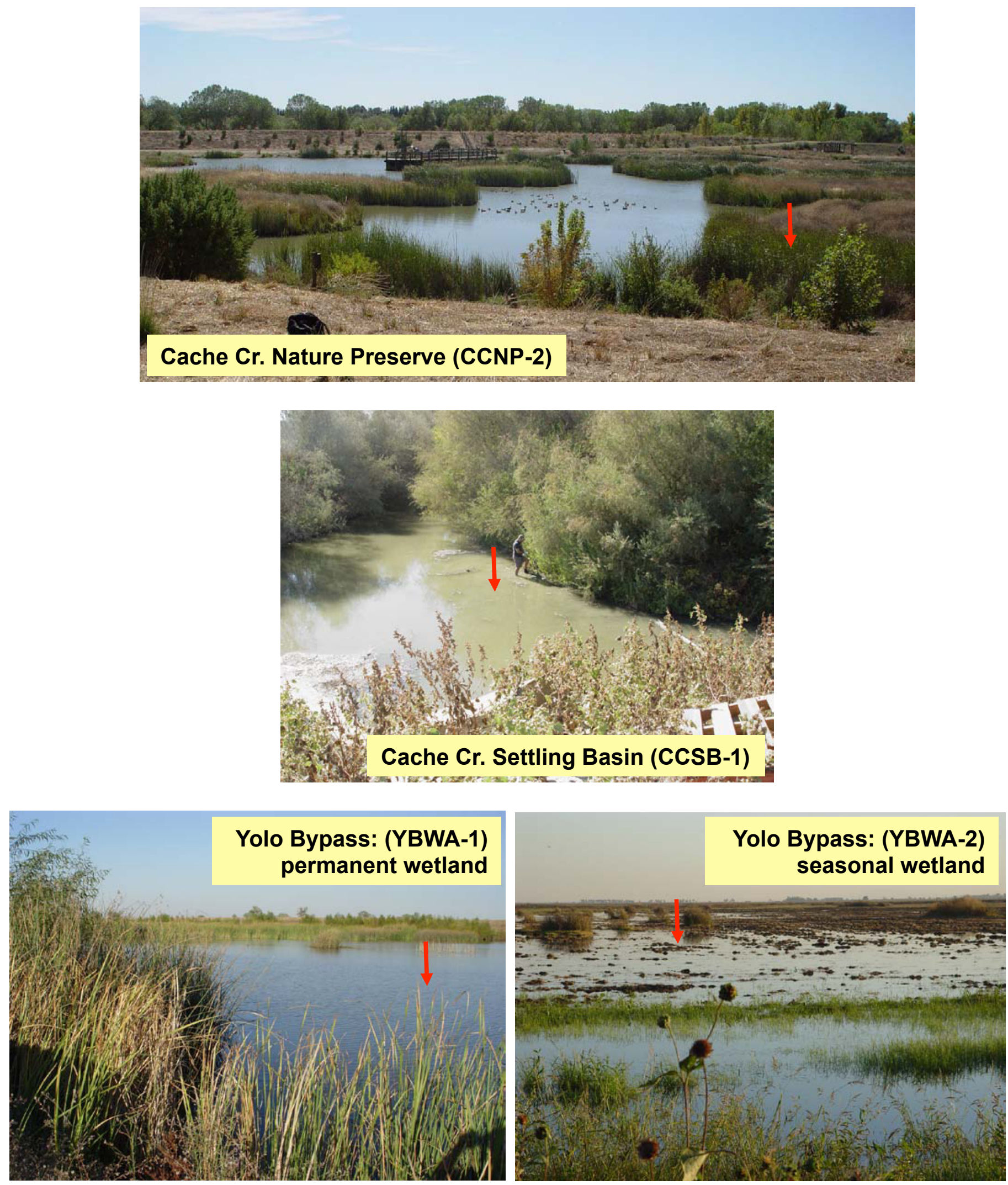

Figure 2. Photographs of sites sampled during study Phase I (October 5, 2005).

Approximate sampling locations are depicted by the red arrow in each case. The two sites in Yolo Bypass (YBWA-1 and YBWA-2) were revisited during the seasonal sampling phase (October 31, 2005 and May 22, 2006). Photo credit: M. Marvin-DiPasquale, U.S. Geological Survey. 

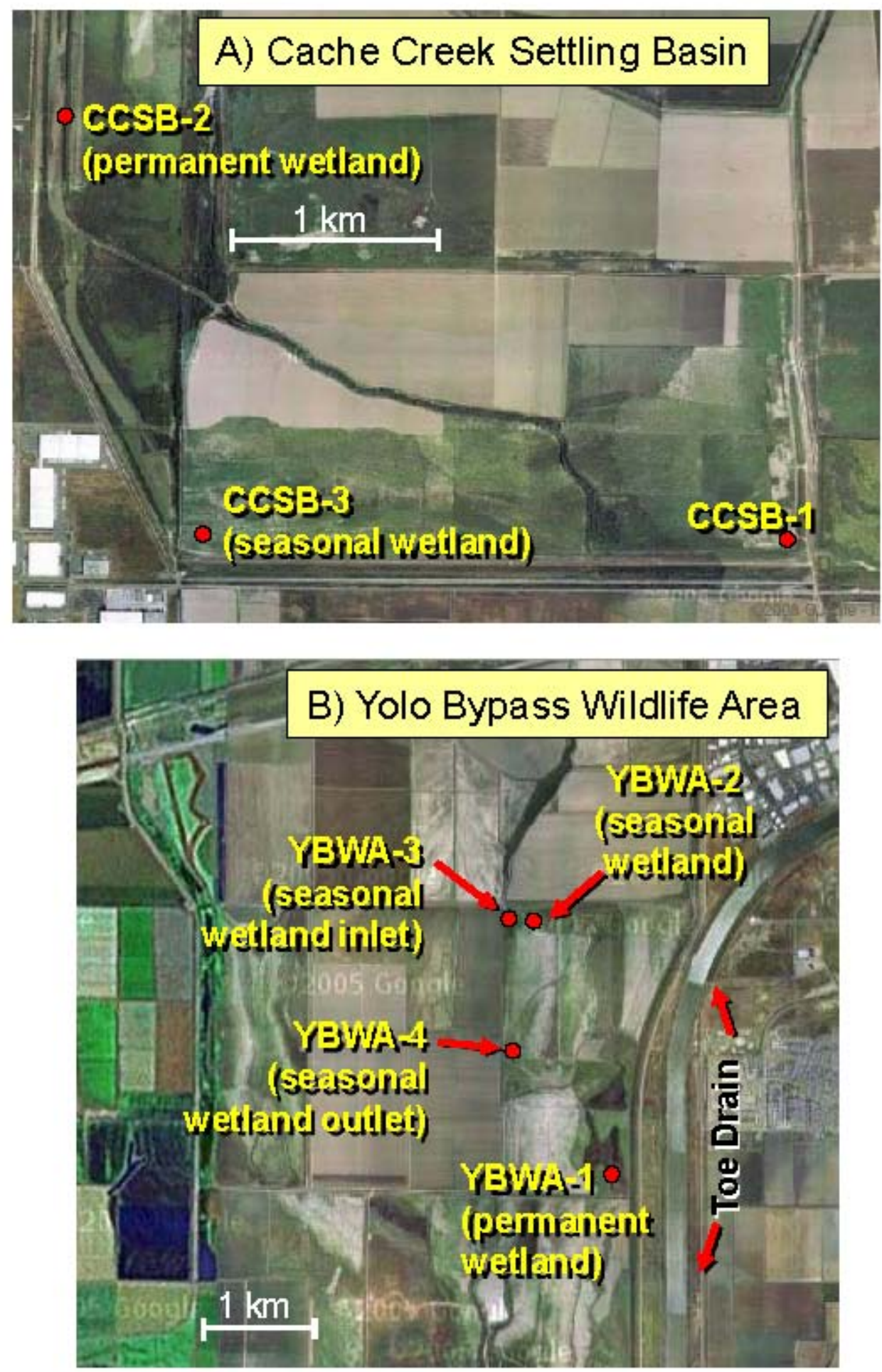

Figure 3. Satellite images of $(A)$ Cache Creek Settling Basin and $(B)$ Yolo Bypass Wildlife Area, depicting the location of sampling sites.

Site CCSB-1 was sampled only during Phase I (October 5, 2007). Phase II seasonal sampling of sediment and water was conducted at CCSB-2, CCSB-3, YBWA-1 and YBWA-2. Only water was sampled at YBWA-3 (October 31, 2005) and YBWA-4 (May 22, 2006), to coincide with the flooding and draining, respectively, of the seasonal wetland area. Satellite images were obtained online from Google Maps. [km, kilometers] 

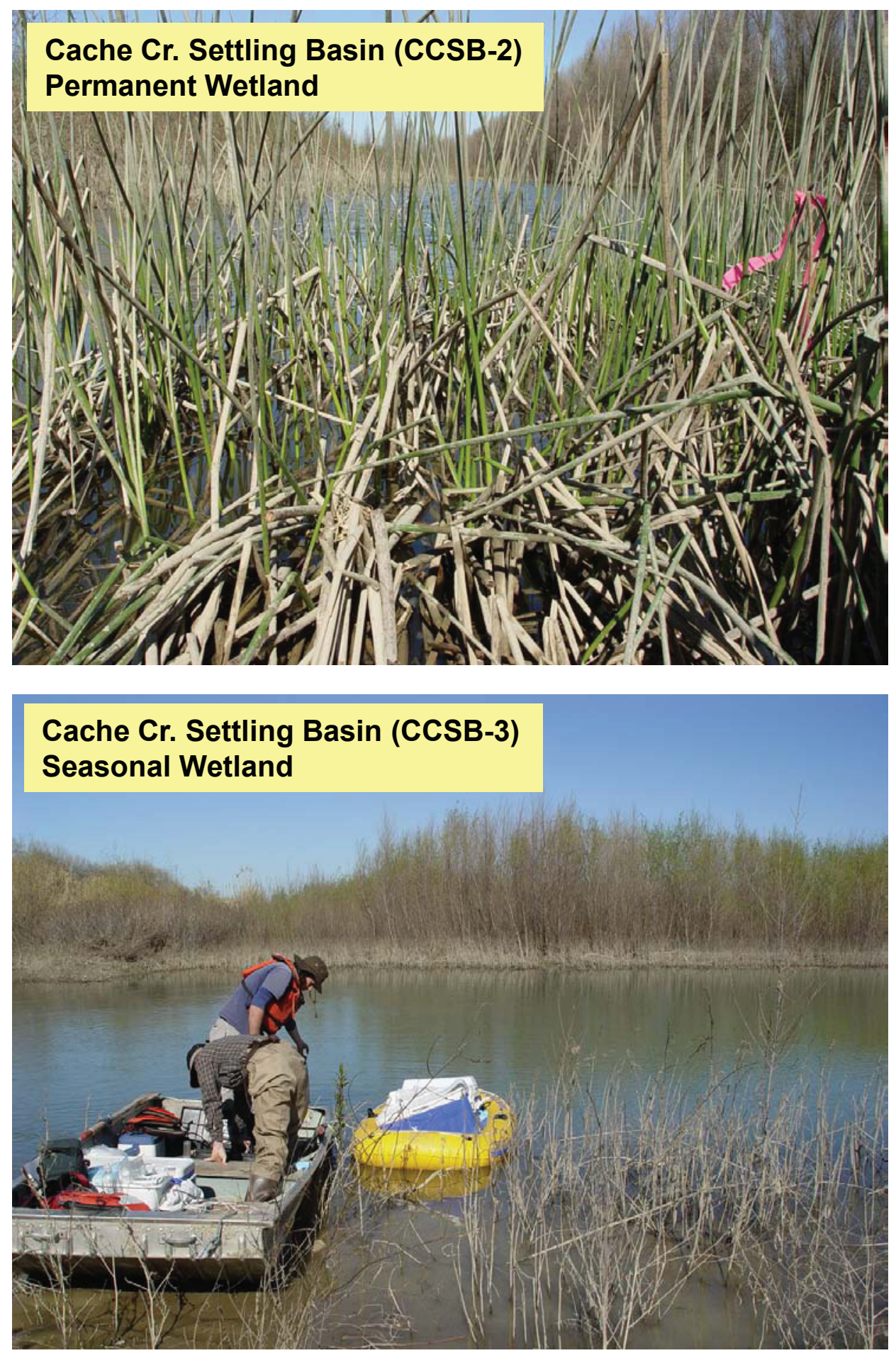

Figure 4. Photographs of the two Cache Creek Settling Basin sites (CCSB-2 and CCSB-3) sampled during study Phase II (February 13, 2006, and May 30, 2006).

Photo credit: M. Marvin-DiPasquale, U.S. Geological Survey. 


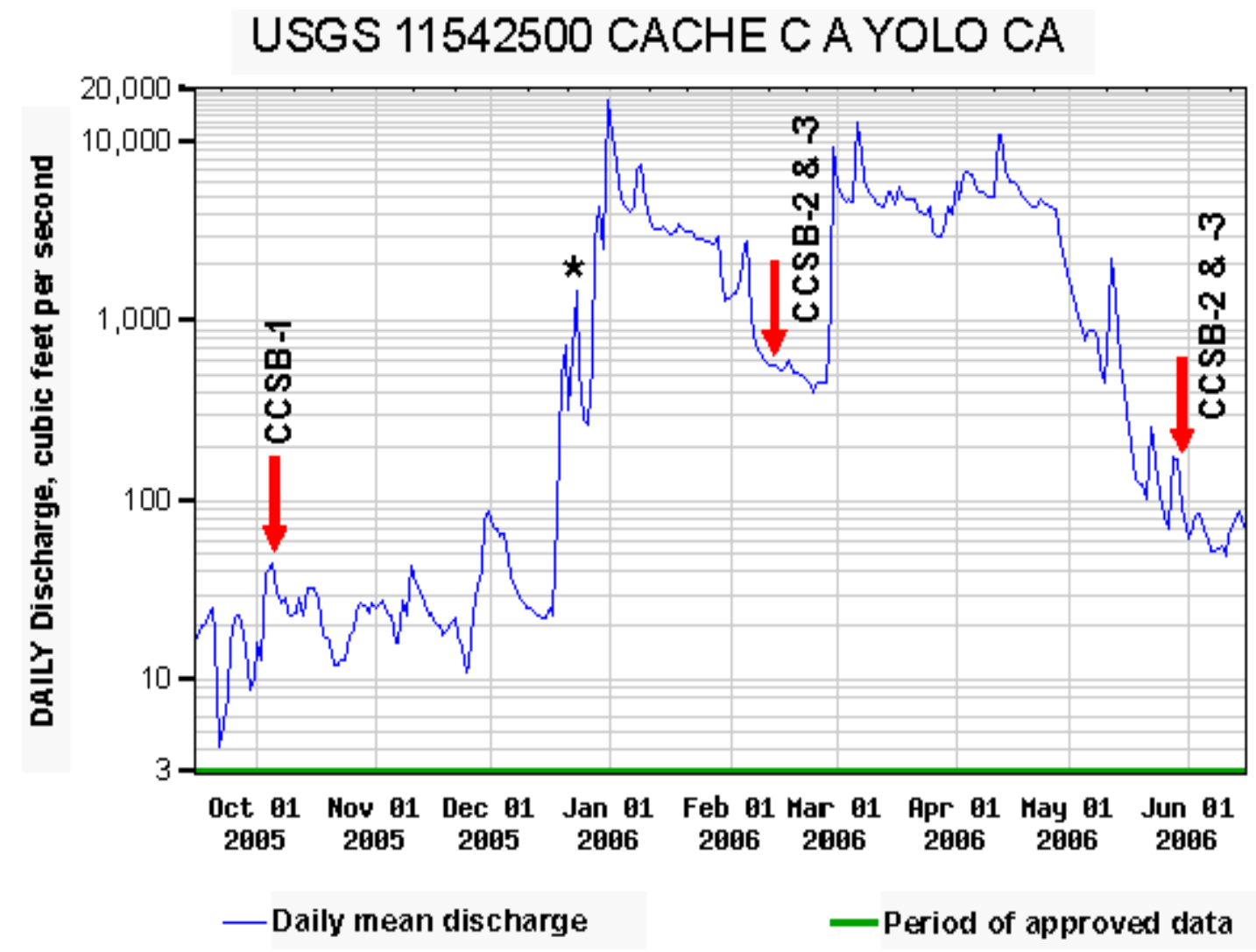

Figure 5. Hydrograph of Cache Creek, California (USGS gaging station 11452500), from September 15, 2005 through June 15, 2006.

Arrows indicate dates that samples were collected at the sites named. The asterisk $(*)$ indicates the most likely date (Dec. 23,2005$)$ that the seasonal wetland (CCSB-3) began flooding. Hydrograph data obtained on-line:

[http://waterdata.usgs.gov/ca/nwis/sw (accessed Sept. 4, 2009)] 


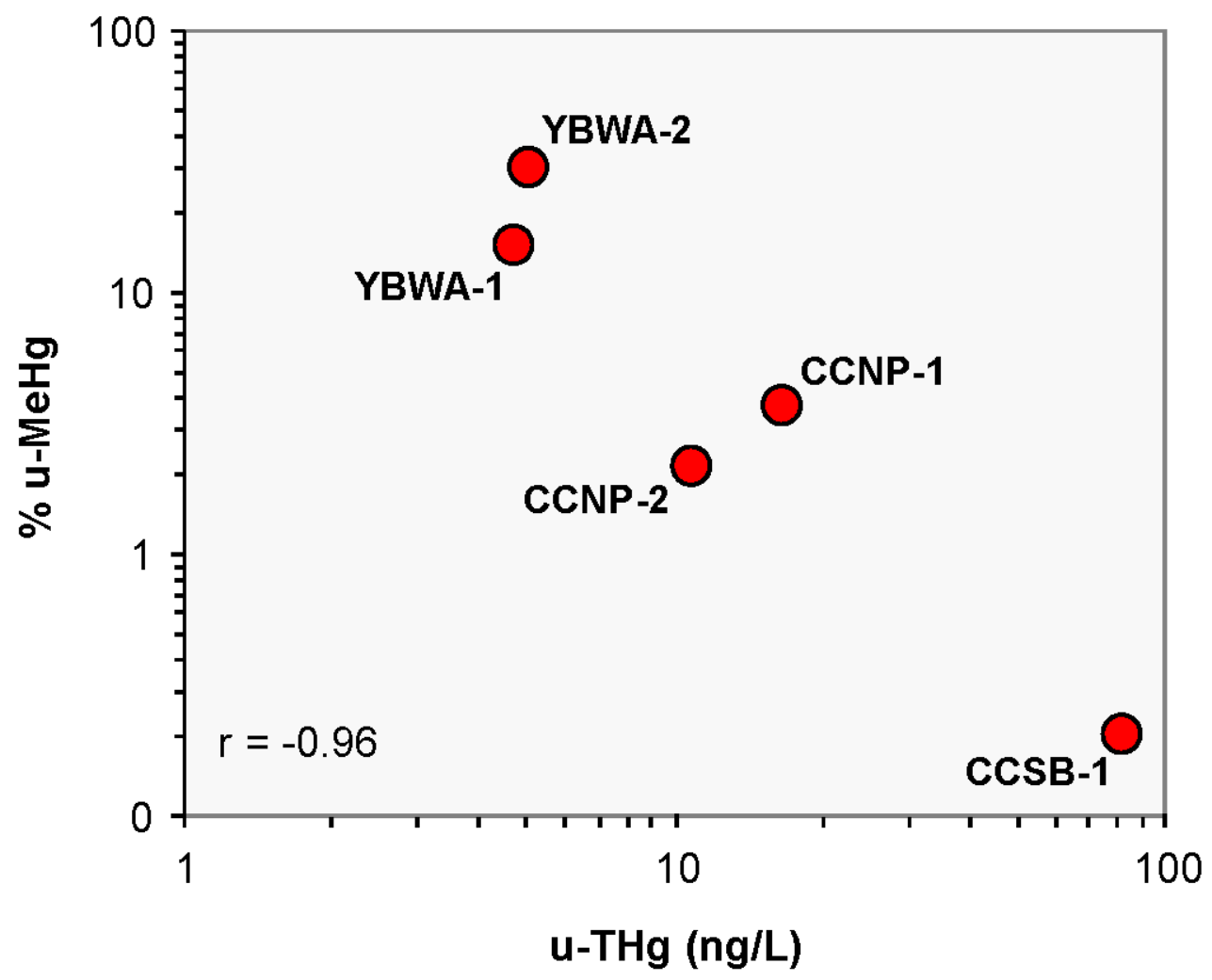

Figure 6. The negative correlation between unfiltered total mercury (u-THg) concentration in surface water and the percentage as methylmercury ( $\% \mathrm{u}-\mathrm{MeHg})$ for sites sampled during study Phase I, within the Cache Creek Nature Preserve (CCNP), Cache Creek Settling Basin (CCSB), and Yolo Bypasss Wildlife Area (YBWA), Yolo County, California. The Pearson correlation coefficient $(r)$ is given for log-log transformed data of both parameters. [ng/L, nanograms per liter] 

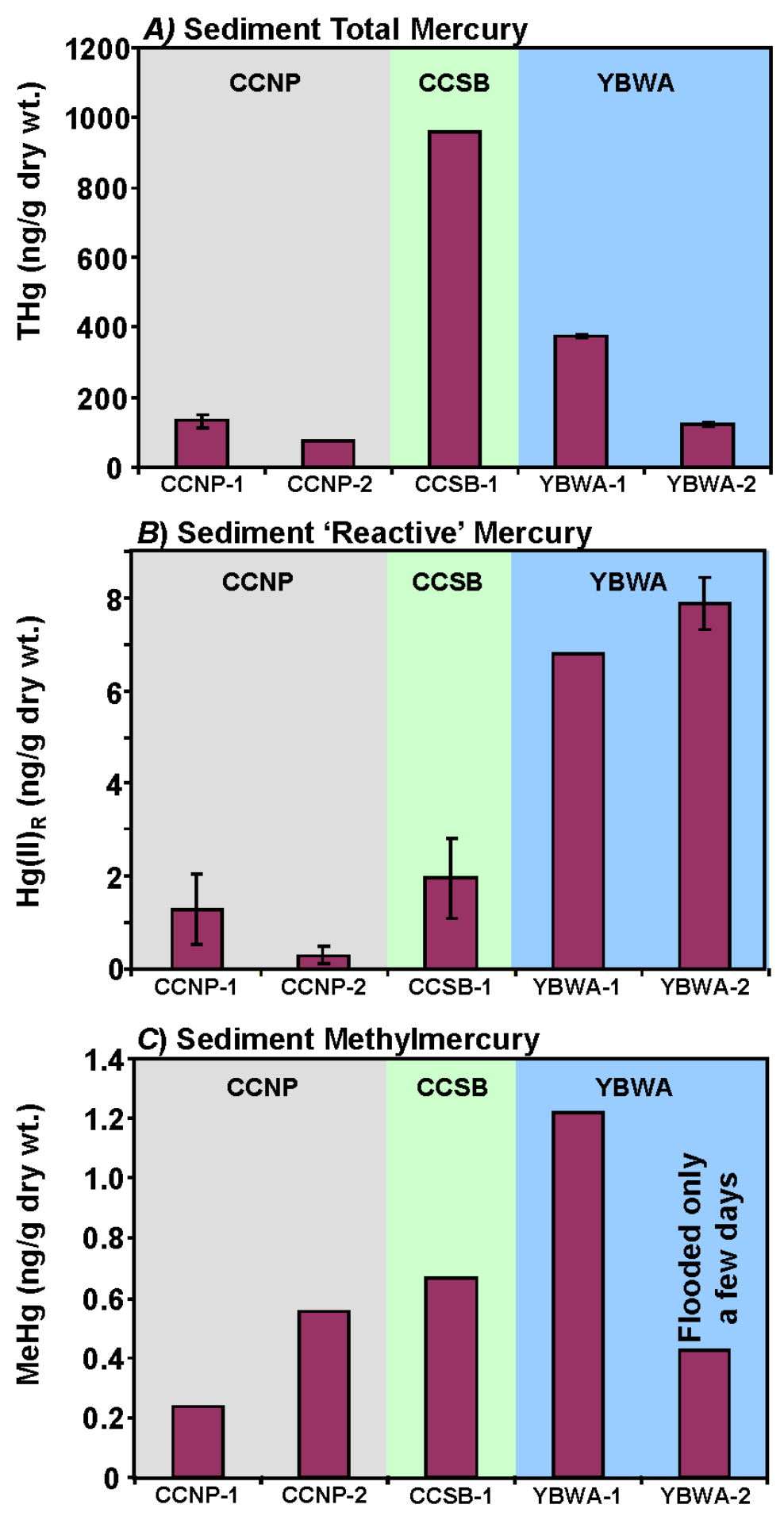

Figure 7. Mercury species in sediment sampled during study Phase I from sites in the Cache Creek Nature Preserve (CCNP), Cache Creek Settling Basin (CCSB), and Yolo ByPass Wildlife Area (YBWA), Yolo County, California.

$A$, Total mercury $(\mathrm{THg}) . B$, Inorganic reactive mercury $\left(\mathrm{Hg}(\mathrm{II})_{\mathrm{R}}\right) . C$, Methylmercury (MeHg). [ng/g, nanograms per gram; wt., weight] 


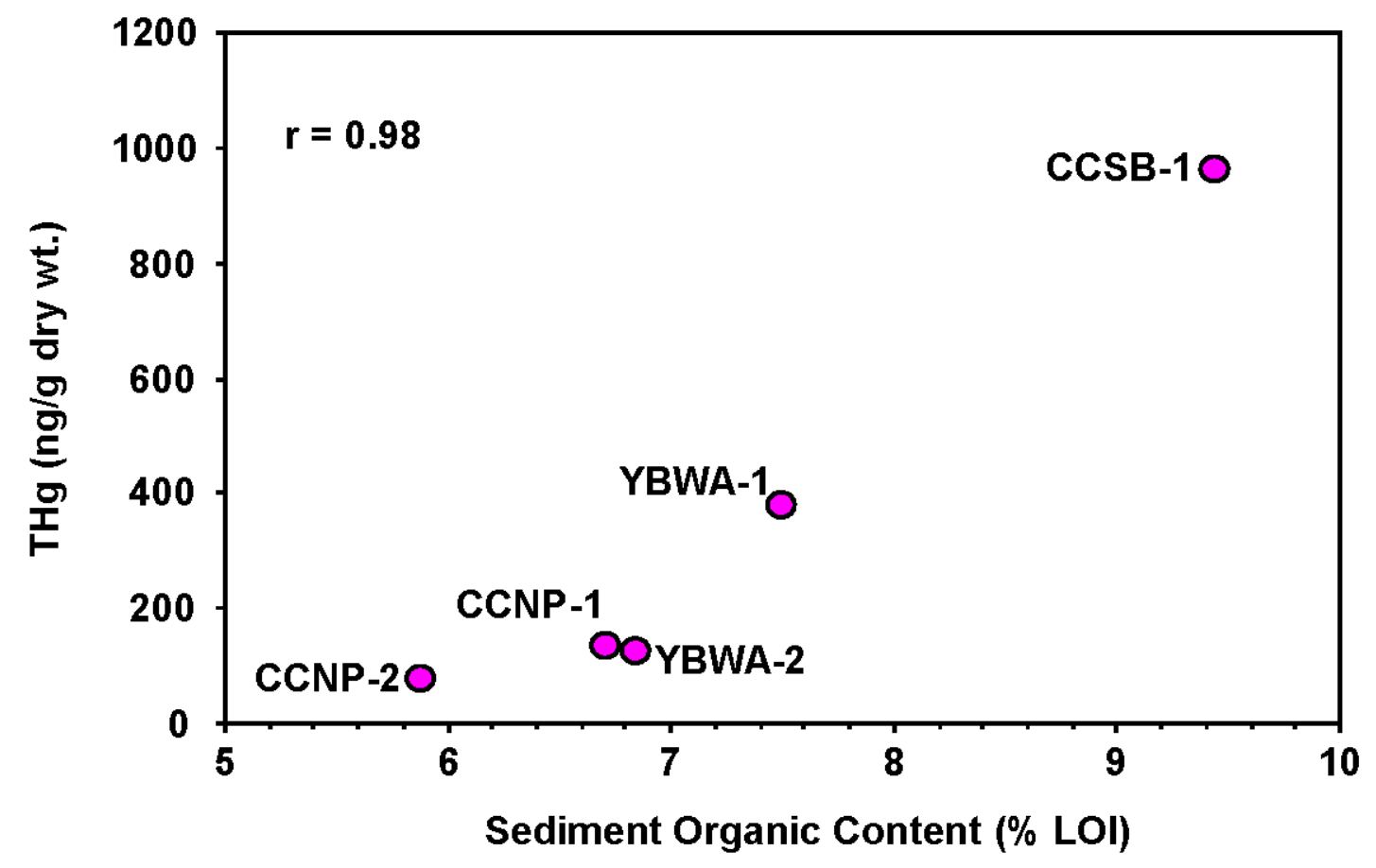

Figure 8. Plot showing the positive correlation between organic content (as \% LOI, Percentage Loss on Ignition) and total mercury ( $\mathrm{THg}$ ) concentration in sediment from Phase I.

The Pearson correlation coefficient ( $r$ ) is given. [ng/g, nanograms per gram; wt., weight] 

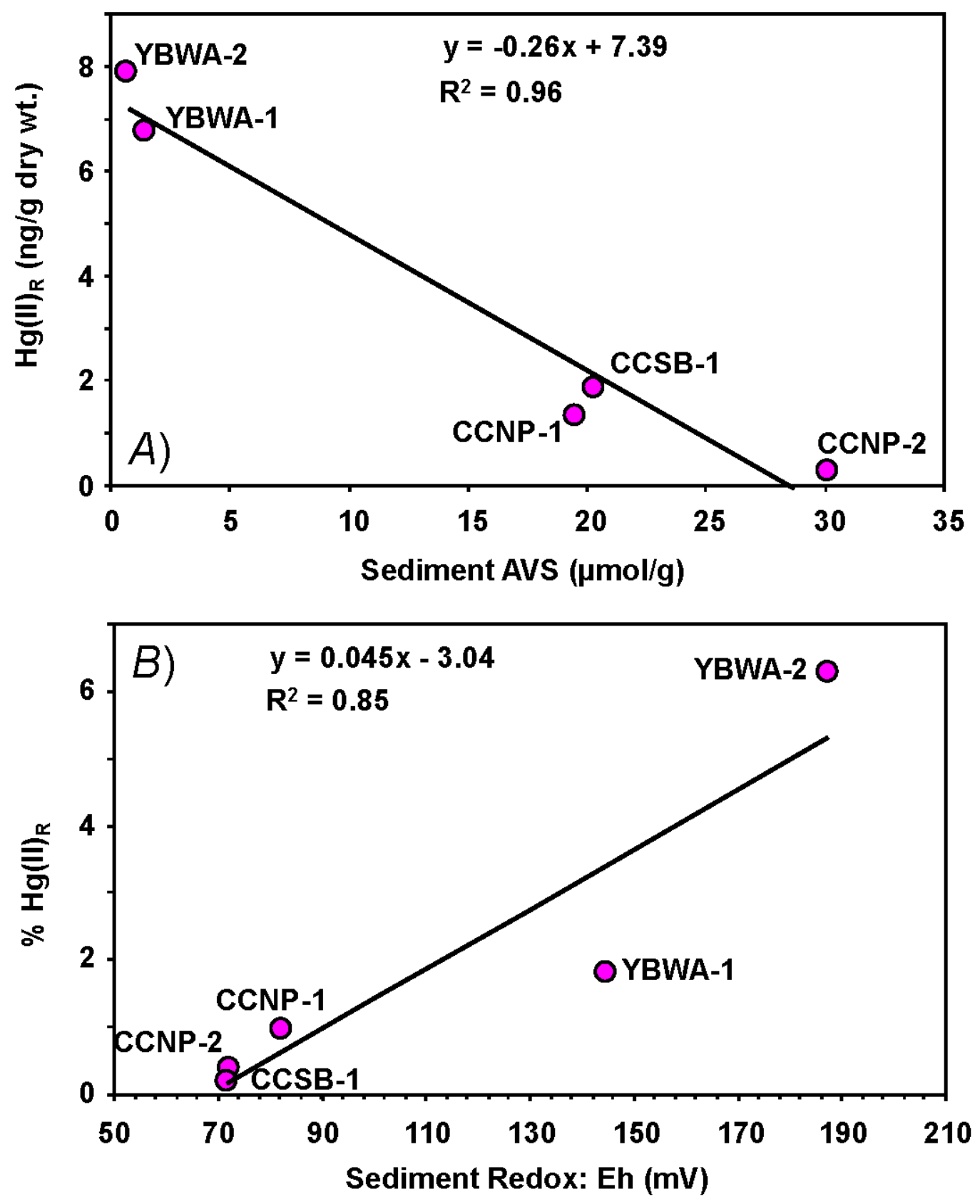

Figure 9. Plots showing $(A)$ the negative relationship between sediment acid volatile sulfur (AVS) and sediment inorganic reactive mercury $\left(\mathrm{Hg}(\mathrm{II})_{R}\right)$ concentrations and $(B)$ the positive relationship between sediment oxidation-reduction potential (Redox) and the percentage of total mercury as $\mathrm{Hg}(\mathrm{II})_{R}\left(\% \mathrm{Hg}(\mathrm{II})_{\mathrm{R}}\right)$ during Phase I.

The least-squares linear regression equation and the associated $R_{2}$ value is shown. [ng/g, nanogram per gram; $\mu \mathrm{mol} / \mathrm{g}$, micromole per gram; $\mathrm{mV}$, millivolt] 

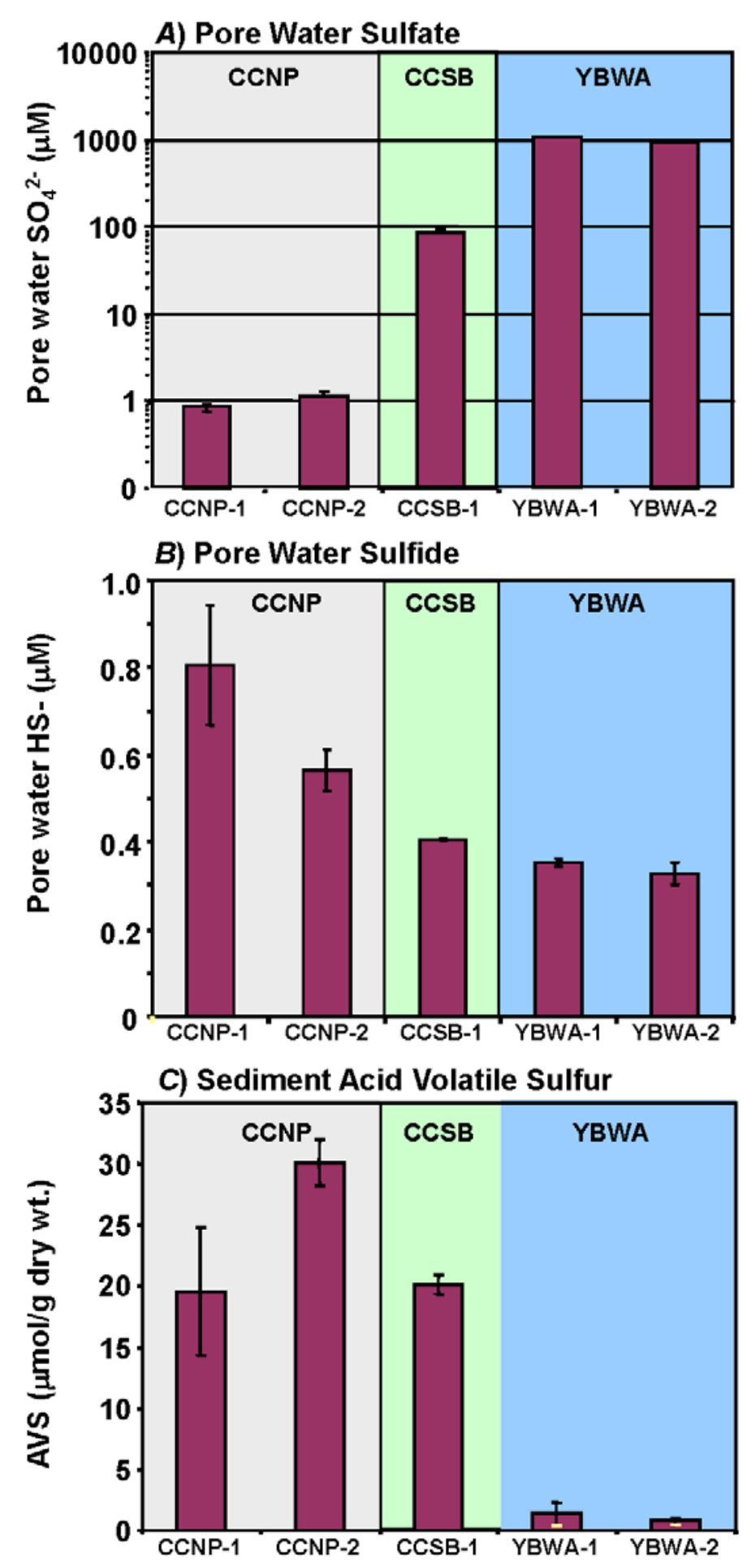

Figure 10. Concentrations of sulfur species in sediment and pore water sampled during Phase I from sites in Cache Creek Nature Preserve (CCNP), Cache Creek Settling Basin (CCSB) and Yolo ByPass Wildlife Area (YBWA), Yolo County, California.

$A$, Pore water sulfate $\left(\mathrm{SO}_{4}{ }^{2-}\right) . B$, Pore water sulfide $\left(\mathrm{HS}^{-}\right)$. $C$, Sediment acid volatile sulfur (AVS). [ $\mu \mathrm{M}$, micromole per liter; $\mu \mathrm{mol} / \mathrm{g}$, micromole per gram; wt., weight] 

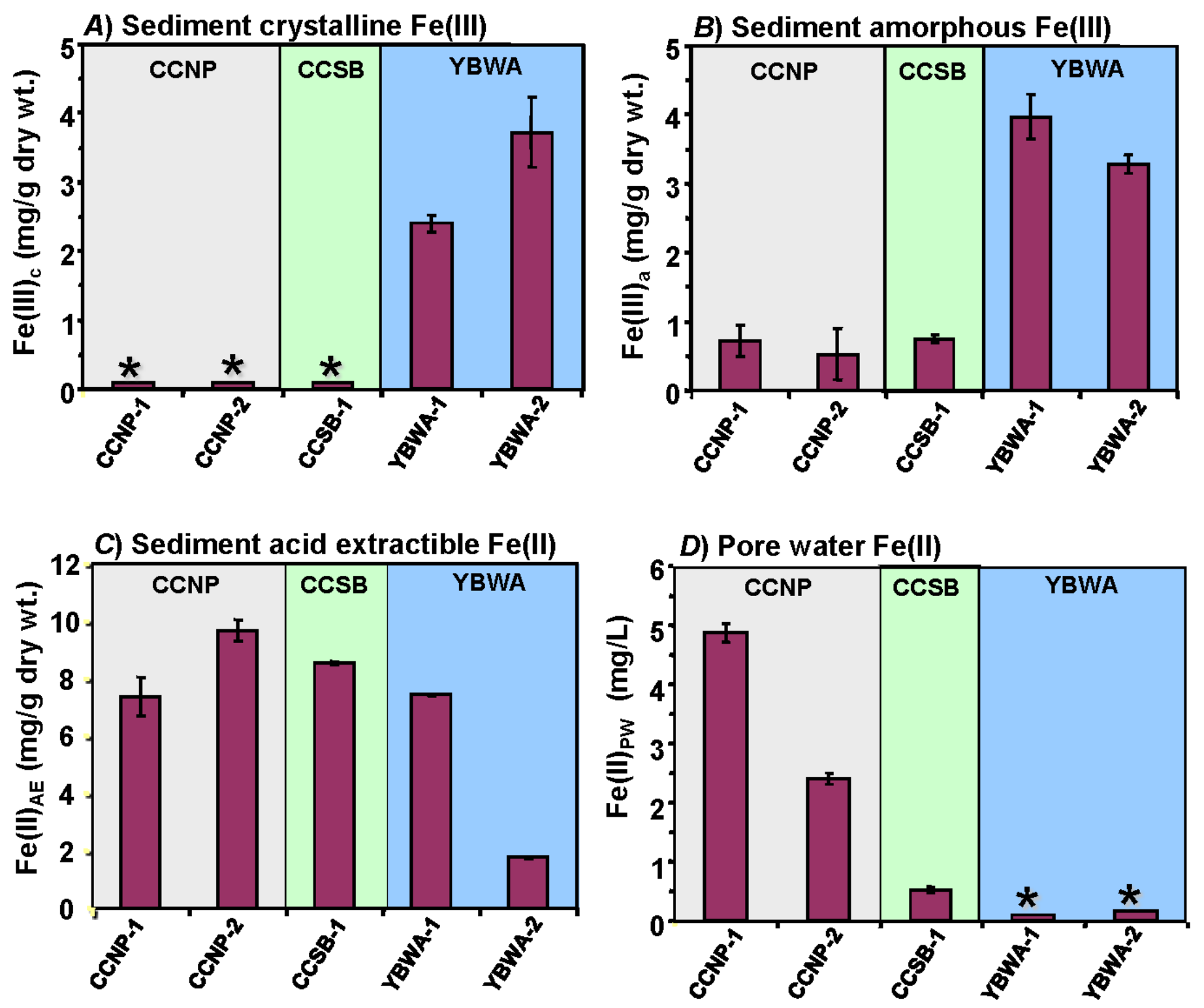

Figure 11. Concentrations of iron species in sediment and pore water sampled during Phase I from sites in Cache Creek Nature Preserve (CCNP), Cache Creek Settling Basin (CCSB) and Yolo ByPass Wildlife Area (YBWA), Yolo County, California.

$A$, Sediment crystalline ferric iron $\left(\mathrm{Fe}(\mathrm{III})_{\mathrm{c}}\right) . B$, Sediment amorphous (poorly crystalline) ferric iron $\left(\mathrm{Fe}(\mathrm{III})_{\mathrm{a}}\right)$. $C$, Sediment acid extractible ferrous iron $\left(\mathrm{Fe}(\mathrm{II})_{\mathrm{AE}}\right)$. $D$, Pore water ferrous iron $\left(\mathrm{Fe}(\mathrm{II})_{\mathrm{PW}}\right)$. An asterisk $(*)$ indicates that the value depicted represents the analytical detection limit. [mg/g, milligram per gram; mg/L, milligram per liter; wt., weight] 


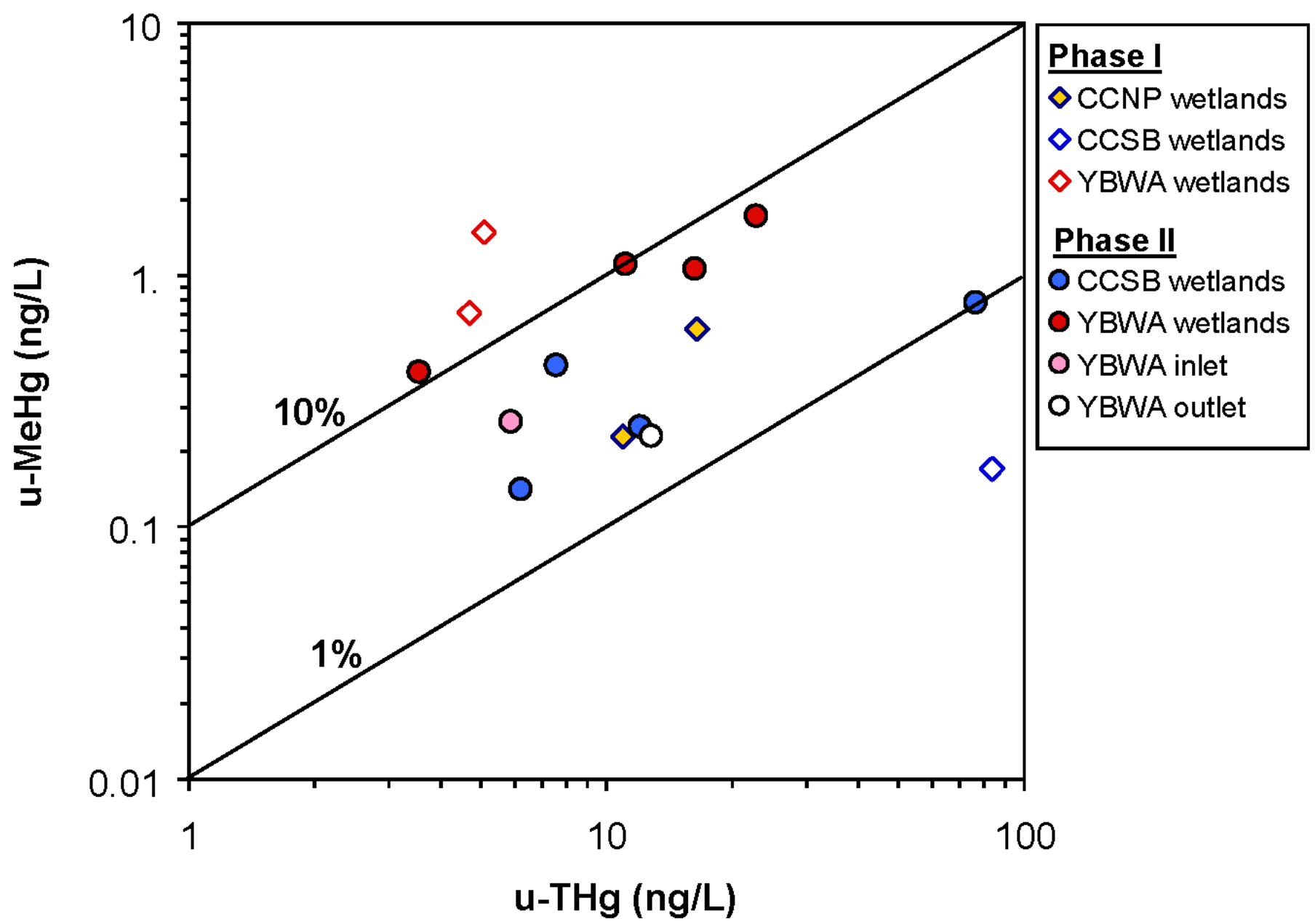

Figure 12. Log-log plot showing the relation between total mercury $(\mathrm{THg})$ and methylmercury $(\mathrm{MeHg}$ ) concentrations in unfiltered waters from seasonal and permanent wetlands of Cache Creek and the Yolo Bypass, California.

Lines of equal percent $\mathrm{THg}$ as $\mathrm{MeHg}(\% \mathrm{MeHg})$ are shown for comparison. Data are presented both as function of sampling area [CCNP, Cache Creek Nature Preserve; CCSB, Cache Creek Settling Basin; YBWA, Yolo Bypass Wildlife Area] and by project sampling phase [Phase I or II]. Note logarithmic scales. The YBWA inlet and outlet sites are associated with the seasonal wetland area only. [ng/L, nanogram per liter] 

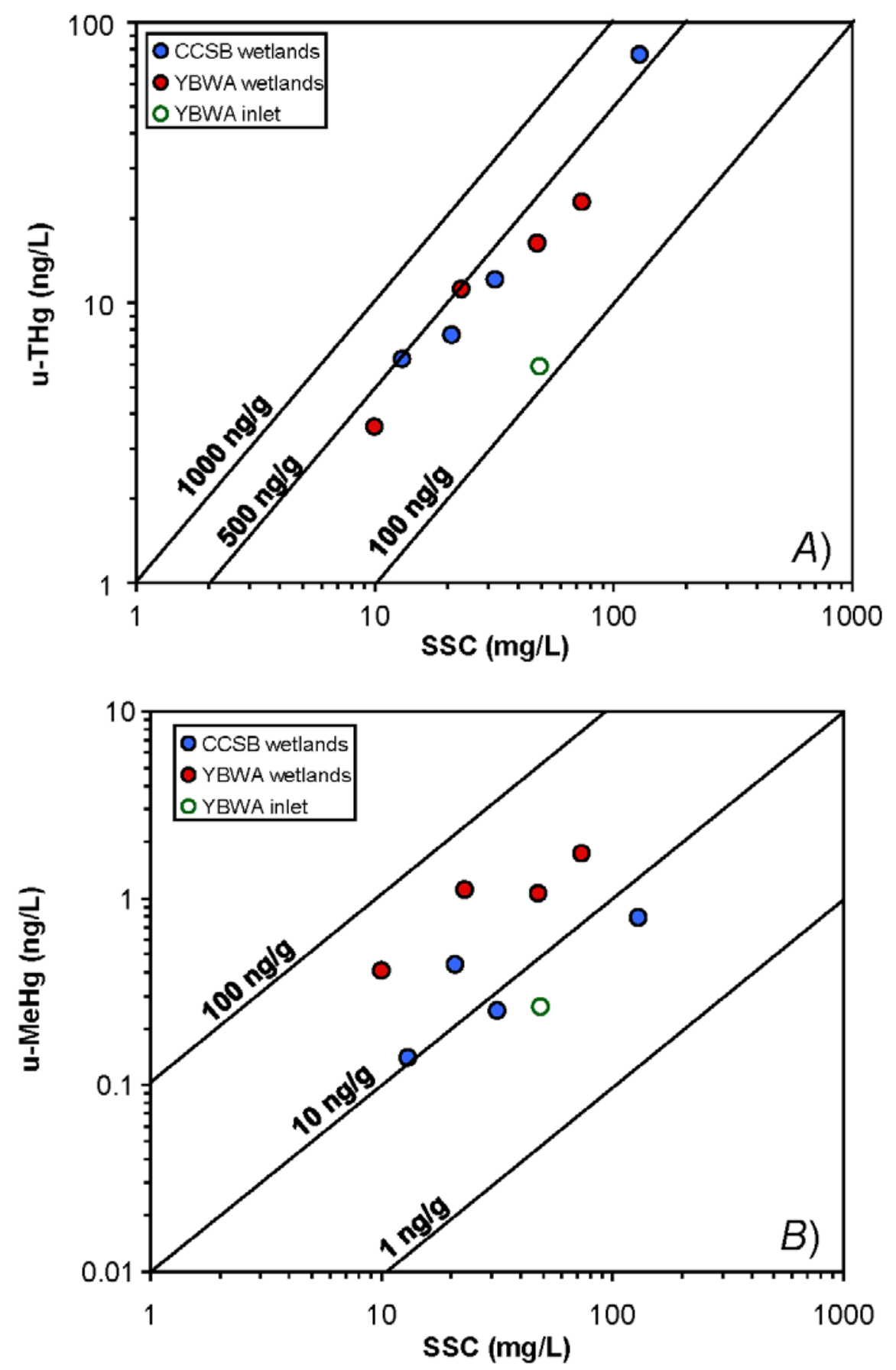

Figure 13. Log-log plots showing the relation between surface water suspended sediment concentration (SSC) and $(A)$ unfiltered total mercury (u-THg) and $(B)$ unfiltered methylmercury (u-MeHg) concentrations in seasonal and permanent wetlands of Cache Creek Settling Basin (CCSB) and the Yolo Bypass Wildlife Area (YBWA), Yolo County, California. Phase II sampling data only.

Lines of equal concentration particulate $\mathrm{THg}$ or $\mathrm{MeHg}$ (e.g. p-THg or p-MeHg) are shown for comparison. The YBWA inlet site is associated with the seasonal wetland area only. [ng/L, nanogram per liter; $\mathrm{mg} / \mathrm{L}$, milliram per liter] 


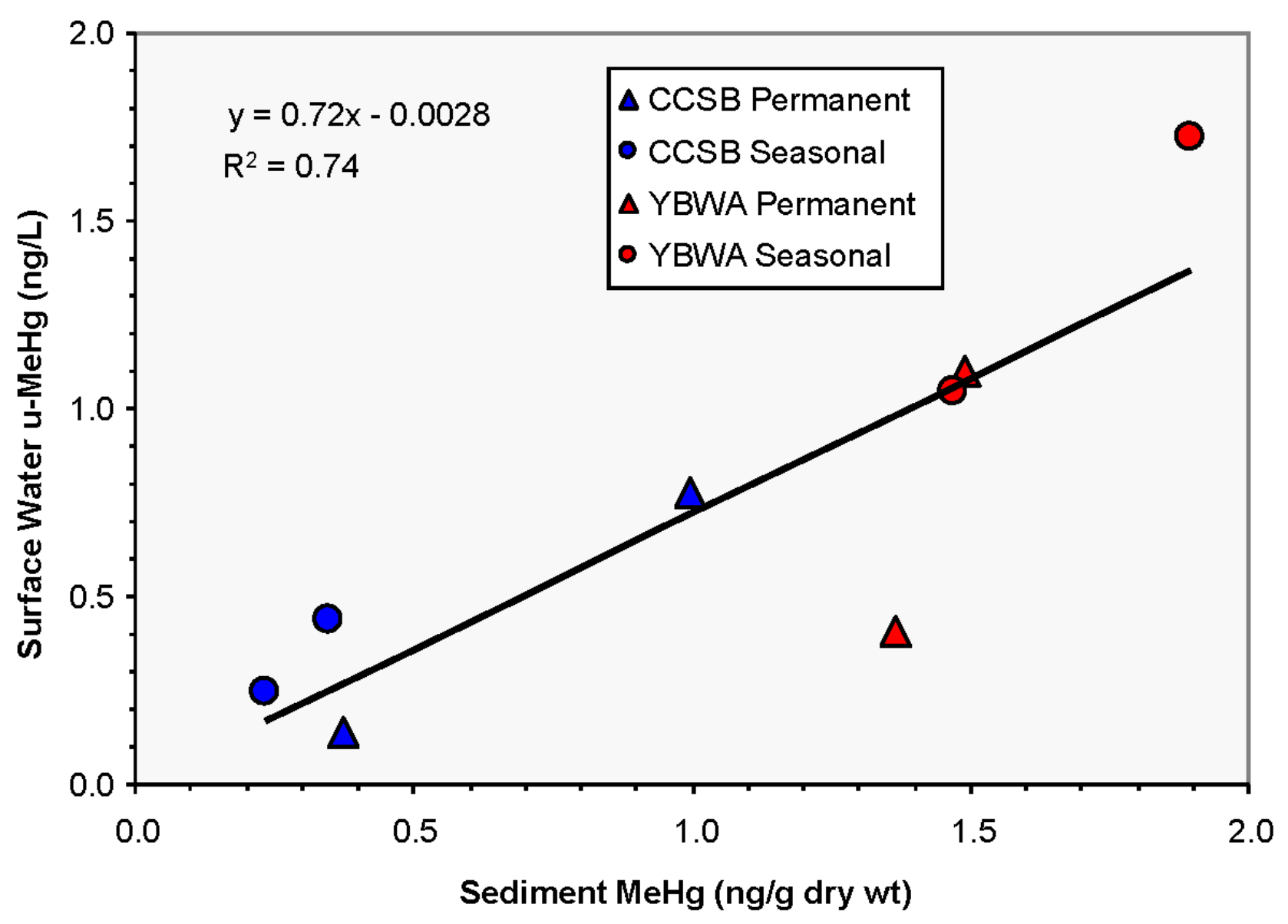

Figure 14. Plot showing the linear relation between methylmercury $(\mathrm{MeHg})$ concentration in bed sediment and in unfiltered surface water during study Phase II from permanent and seasonal wetland sites in the Cache Creek Settling Basin (CCSB) and the Yolo Bypass Wildlife Area (YBWA), Yolo County, California.

The least-squares linear regression equation and the associated $R^{2}$ value is shown. [ng/L, nanogram per liter; ng/g, nanogram per gram; wt, weight] 

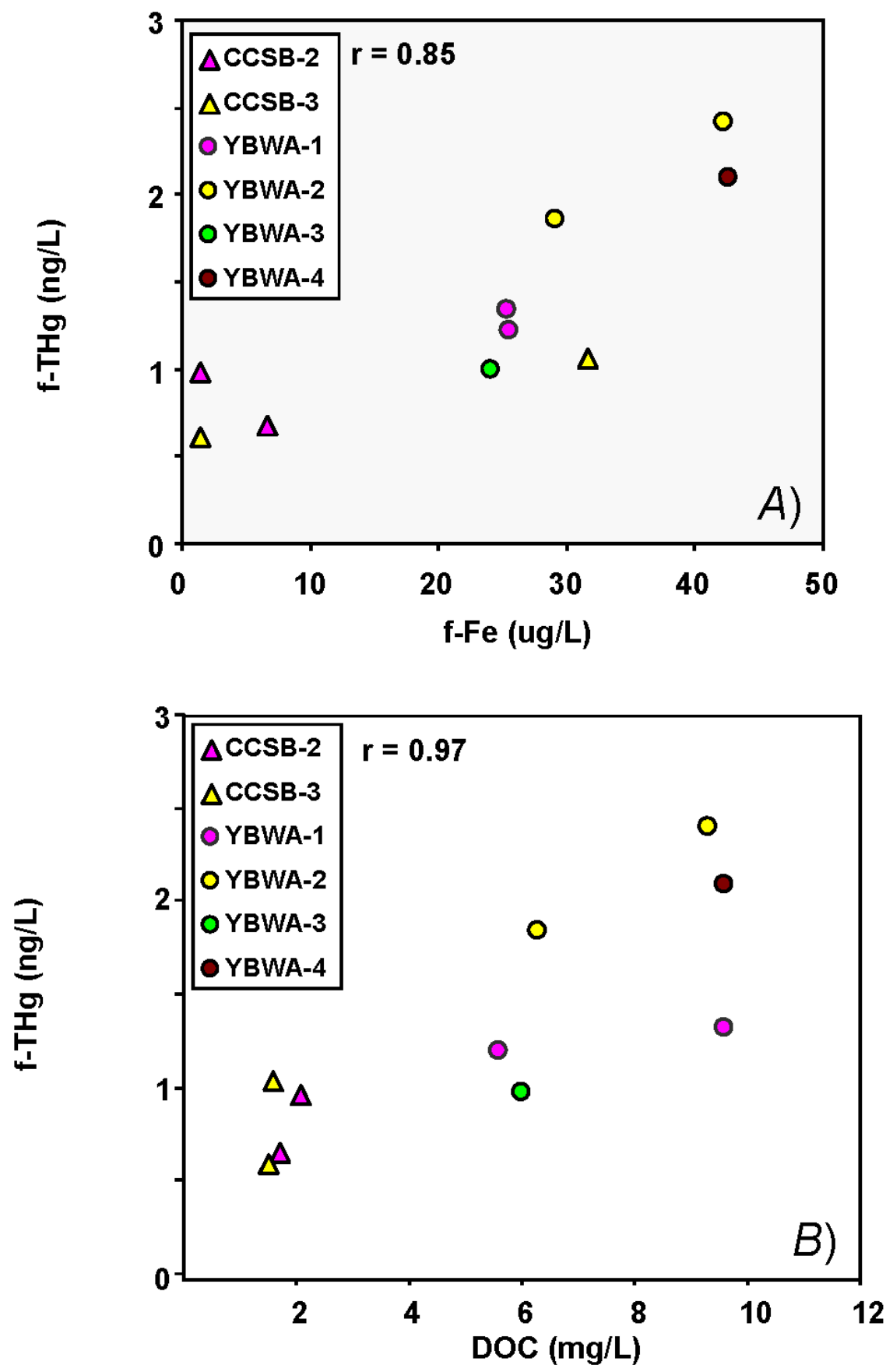

Figure 15. Plots showing correlations among water quality parameters in samples collected during Phase II from seasonal and permanent wetlands of Cache Creek Settling Basin (CCSB) and the Yolo Bypass Wildlife Area (YBWA), Yolo County, California.

$A$, Filter-passing total iron (f-Fe) vs filter-passing total mercury (f-THg) in surface water. $B$, Dissolved organic carbon (DOC) vs $\mathrm{f}-\mathrm{THg}$ in surface water. The Pearson correlation coefficient $(r)$ is given in each case. [ng/L, nanogram per liter; $\mu \mathrm{g} / \mathrm{L}$, microgram per liter; $\mathrm{mg} / \mathrm{L}$, milligram per liter] 

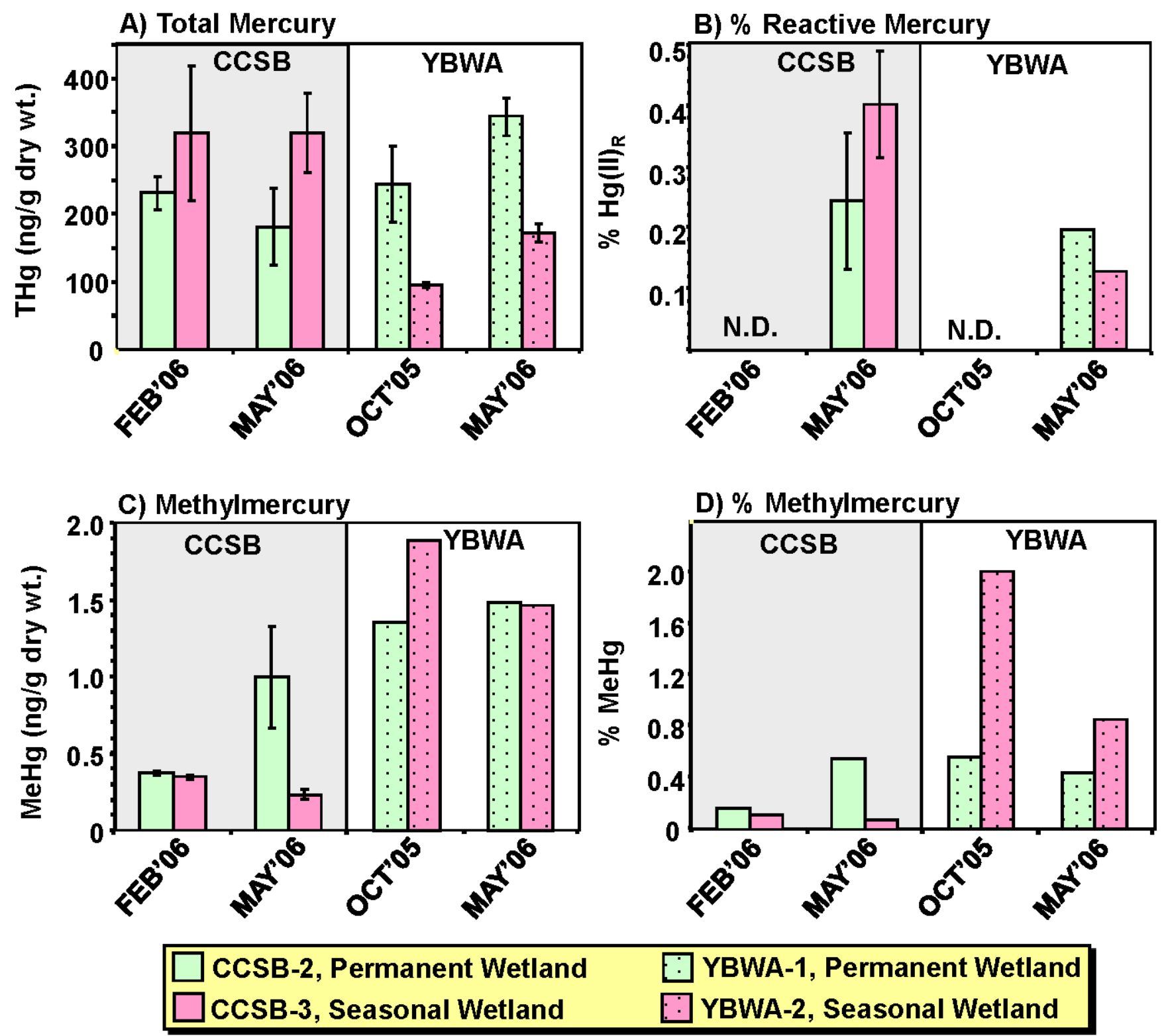

Figure 16. Concentrations of sediment mercury species during study Phase II in permanent and seasonal wetland sites, in the Cache Creek Settling Basin (CCSB) and the Yolo Bypass Wildlife Area (WBWA), Yolo County, California.

$A$, Sediment total mercury (THg). $B$, Sediment percentage of $\mathrm{THg}$ as inorganic reactive mercury $\left(\% \mathrm{Hg}(\mathrm{II})_{\mathrm{R}}\right) . C$, Sediment methylmercury $(\mathrm{MeHg}) . D$, Sediment percentage of $\mathrm{THg}$ as $\mathrm{MeHg}(\% \mathrm{MeHg})$. Paired seasonal and permanent wetland areas, for each region, are organized according to sampling month-year. N.D. indicates that No Data was collected. [ng/g, nanogram per gram; wt., weight] 


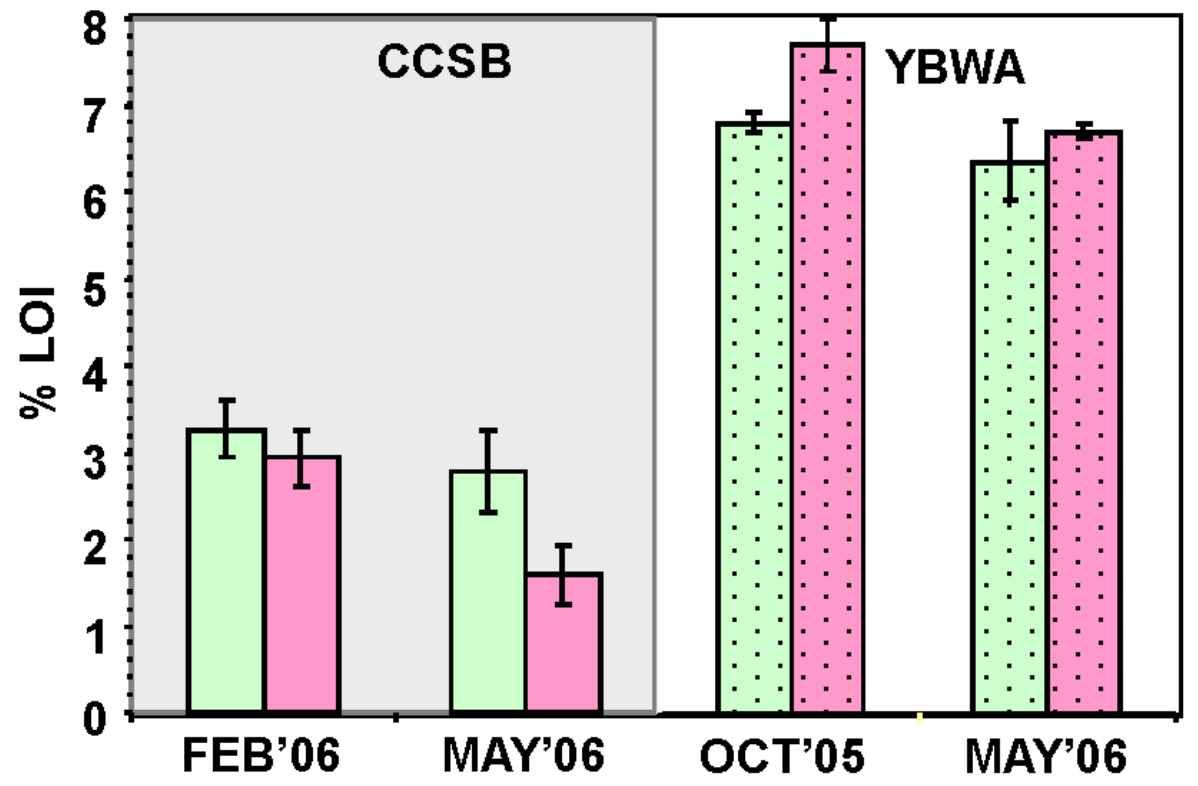

\begin{tabular}{|ll|}
\hline ccsB-2, Permanent Wetland & $\square$ YBWA-1, Permanent Wetland \\
$\square$ ccsB-3, Seasonal Wetland & $\square$ YBWA-2, Seasonal Wetland
\end{tabular}

Figure 17. Concentrations of sediment organic content during study Phase II for permanent and seasonal wetland sites in the Cache Creek Settling Basin (CCSB) and the Yolo Bypass Wildlife Area (YBWA), Yolo County, California.

Organic content is expressed as the percentage weight loss on ignition (\%LOI) at $500^{\circ} \mathrm{C}$. Paired seasonal and permanent wetland areas, for each region, are organized according to sampling month-year. 

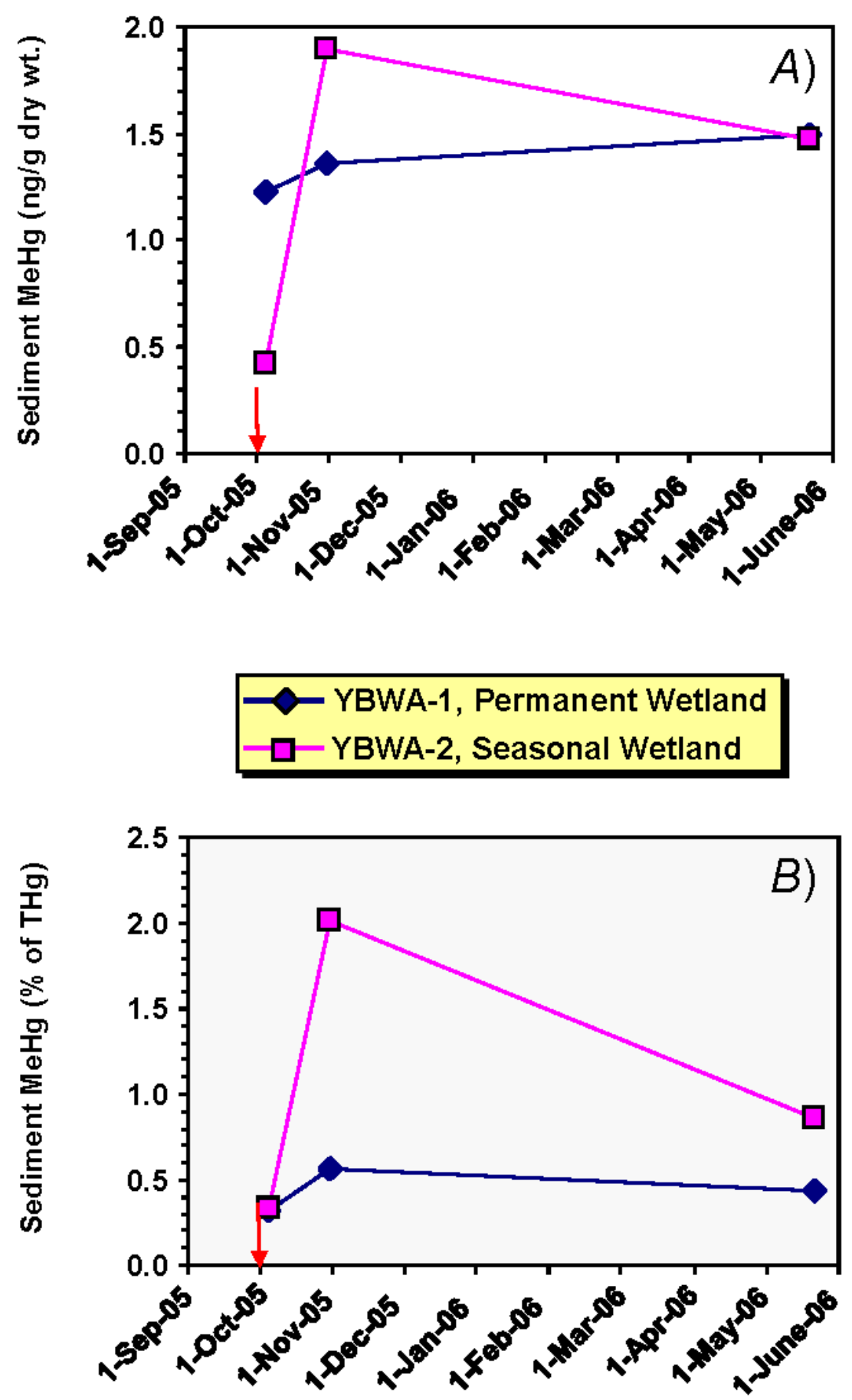

Figure 18. Time series of (A) methylmercury (MeHg) concentration and (B) the percentage of total mercury as $\mathrm{MeHg}(\% \mathrm{MeHg})$ in surface sediment $(0-2 \mathrm{~cm})$ of the permanent and seasonal wetlands sites in the Yolo Bypass Wildlife Area, Yolo County, California.

The red arrow indicates the date the seasonal wetland began flooding (two day prior to initial sediment sampling). [ng/g, nanogram per gram] 

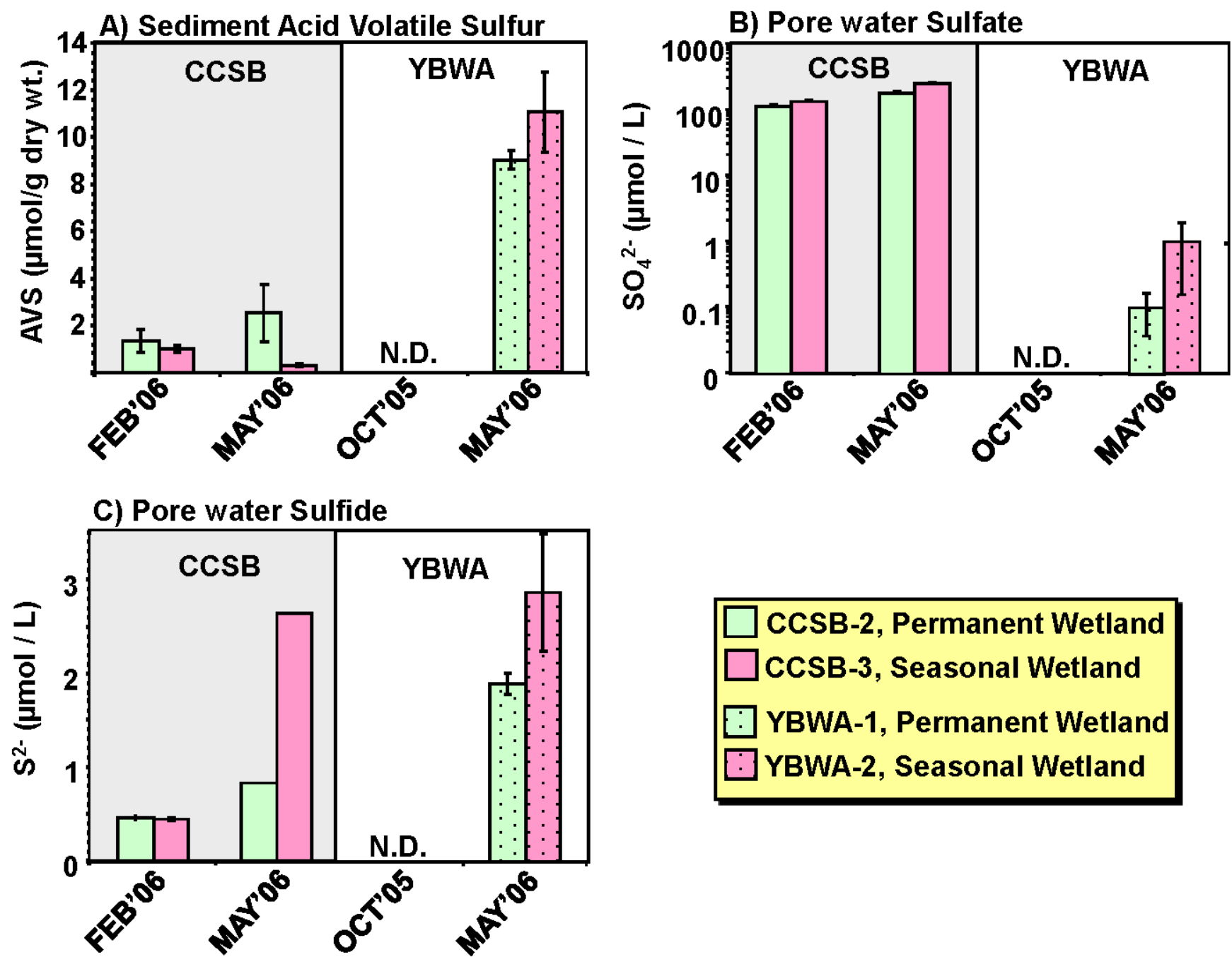

Figure 19. Concentrations of sulfur species in sediment and pore water during study Phase II, for permanent and seasonal wetland sites in the Cache Creek Settling Basin (CCSB) and the Yolo Bypass Wildlife Area (YBWA), Yolo County, California.

$A$, Sediment acid volatile sulfur (AVS). B, Pore water sulfate $\left(\mathrm{SO}_{4}{ }^{2-}\right) . C$, Pore water sulfide $\left(\mathrm{S}^{2-}\right)$. Paired seasonal and permanent wetland areas, for each region, are organized according to sampling month-year. N.D. indicates that 'no data' were collected. [ $\mu \mathrm{mol} / \mathrm{L}$, micromole per liter] 

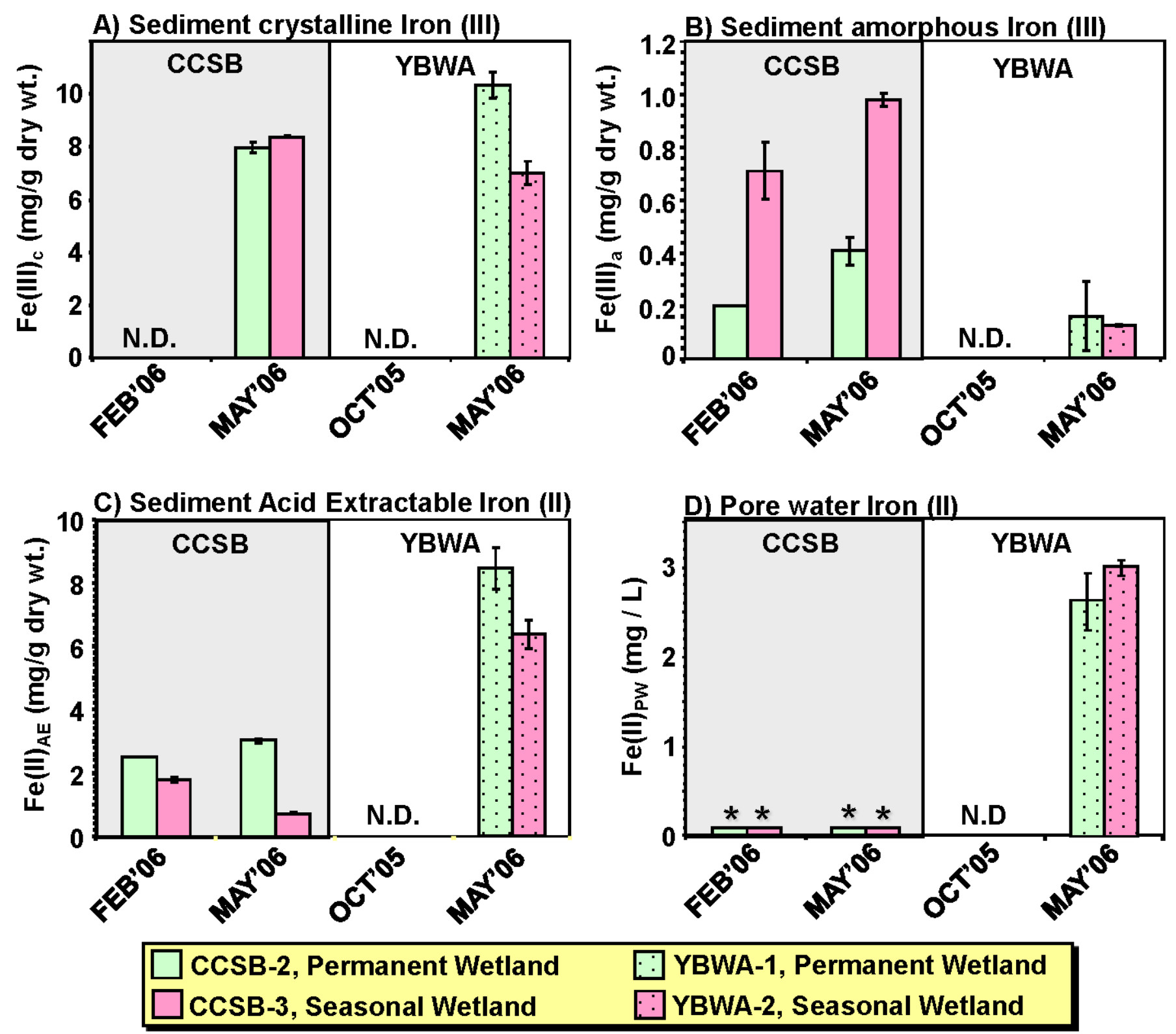

Figure 20. Concentration of iron species in sediment and pore water during study Phase II, for permanent and seasonal wetland sites in the Cache Creek Settling Basin (CCSB) and the Yolo Bypass Wildlife Area (WBWA), Yolo County, California.

$A$, Sediment crystalline ferric iron $\left(\mathrm{Fe}(\mathrm{III})_{\mathrm{c}}\right)$. B, Sediment amorphous (poorly crystalline) ferric iron $\left(\mathrm{Fe}(\mathrm{III})_{\mathrm{a}}\right)$. $C$, Sediment acid extractible ferrous iron $\left(\mathrm{Fe}(\mathrm{II})_{\mathrm{AE}}\right)$. $D$, Pore water ferrous iron $\left(\mathrm{Fe}(\mathrm{II})_{\mathrm{PW}}\right)$. Paired seasonal and permanent wetland areas, for each region, are organized according to sampling month-year. N.D. indicates that No Data was collected. An asterisk (*) indicates that the value depicted represents the analytical detection limit. [mg/g, milligram per gram; $\mathrm{mg} / \mathrm{L}$, milligram per liter; wt., weight] 
Table 1. Parameters analyzed in sediment and surface water during study Phases I and II, Cache Creek and Yolo Bypass, Yolo County, California.

[THg, total mercury; $\mathrm{MeHg}$, methylmercury; $\mathrm{Hg}(\mathrm{II})_{\mathrm{R}}$, inorganic reactive mercury; LOI, weight loss on ignition at $450^{\circ} \mathrm{C}$ (a measure of organic content); AVS, acid volatile sulfur; Fe speciation, included the fractions: acid extracable ferrous iron, acid extractable amorphous (poorly crystalline) ferric iron and crystalline ferric iron; $\mathrm{E}_{\mathrm{h}}$, sediment oxidation-reduction potential corrected for the standard hydrogen halfcell reaction; DOC, dissolved organic carbon; Fe(II), filter-passing ferrous iron; SSC, suspended solids concentrations; SC, specific conductance; SUVA, specific ultra-violet absorption (a measure of DOC aromaticity); POC, particulate organic carbon; O isotopes, oxygen isotopes (ratio of atomic weights 16 and 18); S isotopes, sulfur isotopes (ratio of atomic weights 32 and 34); XAD Fractionation, technique for seperating operationally defined fractions of dissolved organic carbon]

A. Sediment Parameters
\begin{tabular}{|l|l||l|l|}
\hline \multicolumn{2}{|c||}{ Phase I: Reconnaissance } & \multicolumn{2}{c|}{ Phase II: Seasonal } \\
\hline Whole sediment & Pore water & Whole sediment & Pore water \\
\hline $\mathrm{THg}$ & $\mathrm{DOC}$ & $\mathrm{THg}$ & $\mathrm{DOC}$ \\
$\mathrm{MeHg}$ & $\mathrm{Fe}(\mathrm{II})$ & $\mathrm{MeHg}$ & $\mathrm{Fe}(\mathrm{II})$ \\
$\mathrm{Hg}(\mathrm{II})_{\mathrm{R}}$ & Sulfate & $\mathrm{Hg}(\mathrm{II})_{\mathrm{R}}$ & Sulfate \\
dry weight & Chloride & dry weight & Chloride \\
bulk density & Sulfide & bulk density & Sulfide \\
Porosity & Acetate & Porosity & \\
LOI & & LOI & \\
AVS & & AVS & \\
Fe Speciation & & Fe Speciation & \\
$\mathrm{E}_{\mathrm{h}}$ & & E & \\
pH & & pH & \\
\hline
\end{tabular}

B. Surface Water Parameters

\begin{tabular}{|l|l||l|l|}
\hline \multicolumn{2}{|c||}{ Phase I: Reconnaissance } & \multicolumn{2}{c|}{ Phase II: Seasonal } \\
\hline Unfiltered & Filter-Passing & \multicolumn{1}{c|}{ Unfiltered } & \multicolumn{1}{c|}{ Filter-Passing } \\
\hline $\mathrm{MeHg}$ & DOC & $\mathrm{MeHg}$ & $\mathrm{MeHg}$ \\
$\mathrm{THg}$ & SUVA & $\mathrm{THg}$ & $\mathrm{THg}$ \\
$\mathrm{pH}$ & & $\mathrm{SSC}$ & Trace elements \\
$\mathrm{SC}$ & & Nutrients & Major cations \\
& & POC & Anions \\
& & O isotopes in water & S isotopes in sulfate \\
& & pH & Nutrients \\
& & SC & DOC, SUVA \\
& & & XAD fractionation \\
& & & Alkalinity \\
& & & \\
& & & \\
\hline
\end{tabular}


Table 2. Study site locations, sampling dates, and descriptions for Cache Creek and Yolo Bypass, Yolo County, California.

[All sites represent locations where both sediment and water were collected, unless otherwise indicated. Sample collection date is given in the YYYYMMDD format. Latitude and Longitude are given in decimal degrees (DDD.DDDD) using Datum NAD 83.]

\begin{tabular}{|c|c|c|c|c|c|c|}
\hline $\begin{array}{c}\text { USGS Station } \\
\text { Number }\end{array}$ & Site Code & Site Description & $\begin{array}{c}\text { Collection } \\
\text { Date }\end{array}$ & Latitude & Longitude & Comments \\
\hline \multicolumn{7}{|c|}{ PHASE I: RECONNAISSANCE SAMPLING } \\
\hline 384115121524001 & CCNP-1 & Cache Cr. Nature Preserve, SW zone near outflow & 20051005 & 38.6875 & 121.8778 & sediment \& surface water \\
\hline 384126121523001 & CCNP-2 & Cache Cr. Nature Preserve, NW zone & 20051005 & 38.6906 & 121.8750 & sediment \& surface water \\
\hline 384043121402401 & CCSB-1 & Cache Cr. Settling Basin, near SW outlet & 20051005 & 38.6786 & 121.6733 & sediment \& surface water \\
\hline 383150121352801 & YBWA-1 & Yolo Bypass Wildlife Area, Permanent Wetland & 20051005 & 38.5306 & 121.5911 & sediment \& surface water \\
\hline 383309121354701 & YBWA-2 & Yolo Bypass Wildlife Area, Seasonal Wetland & 20051005 & 38.5525 & 121.5964 & sediment \& surface water \\
\hline \multicolumn{7}{|c|}{ PHASE II: SEASONAL SAMPLING } \\
\hline 384154121430001 & CCSB-2 & Cache Cr. Settling Basin, Permanent Wetland & 20060213 & 38.6983 & 121.7167 & sediment \& surface water \\
\hline 384154121430001 & CCSB-2 & Cache Cr. Settling Basin, Permanent Wetland & 20060530 & 38.6983 & 121.7167 & sediment \& surface water \\
\hline 384046121423401 & CCSB-3 & Cache Cr. Settling Basin, Seasonal Wetland & 20060213 & 38.6794 & 121.7094 & sediment \& surface water \\
\hline 384046121423401 & CCSB-3 & Cache Cr. Settling Basin, Seasonal Wetland & 20060530 & 38.6794 & 121.7094 & sediment \& surface water \\
\hline 383150121352801 & YBWA-1 & Yolo Bypass Wildlife Area, Permanent Wetland & 20051031 & 38.5306 & 121.5911 & sediment $\&$ surface water \\
\hline 383150121352801 & YBWA-1 & Yolo Bypass Wildlife Area, Permanent Wetland & 20060522 & 38.5306 & 121.5911 & sediment \& surface water \\
\hline 383309121354701 & YBWA-2 & Yolo Bypass Wildlife Area, Seasonal Wetland & 20051031 & 38.5525 & 121.5964 & sediment \& surface water \\
\hline 383309121354701 & YBWA-2 & Yolo Bypass Wildlife Area, Seasonal Wetland & 20060522 & 38.5525 & 121.5964 & sediment \& surface water \\
\hline 383308121360501 & YBWA-3 & Yolo Bypass, Inflow to seasonal wetland & 20051031 & 38.5522 & 121.6014 & surface water only \\
\hline 383228121360401 & YBWA-4 & Yolo Bypass, Outflow drain from seasonal wetland & 20060522 & 38.5411 & 121.6011 & surface water only \\
\hline
\end{tabular}


Table 3. Data for mercury species in surface water, Cache Creek and Yolo Bypass, Yolo County, California.

[u-THg, unfiltered total mercury; f-THg, filter-passing total mercury; u-MeHg, unfiltered methylmercury; f-MeHg, filter-passing methylmercury; p-THg, particulate total mercury (calculated)a; p-MeHg, particulate methymercury (calculated)b; \%, percentage; N.D., not determined; <, less the given detection limit]

\begin{tabular}{|c|c|c|c|c|c|c|c|c|c|c|c|}
\hline Site Code & $\begin{array}{c}\text { Collection } \\
\text { Date }\end{array}$ & time & $\begin{array}{l}\text { u-THg } \\
\text { (ng/L) }\end{array}$ & $\begin{array}{l}\text { f-THg } \\
\text { (ng/L) }\end{array}$ & $\begin{array}{c}\text { u-MeHg } \\
\text { (ng/L) }\end{array}$ & $\begin{array}{c}\text { f-MeHg } \\
\text { (ng/L) }\end{array}$ & $\begin{array}{c}\text { u-MeHg } \\
\text { (\% of } \\
\text { u-THg) }\end{array}$ & $\begin{array}{c}\text { f-MeHg } \\
\text { ( } \% \text { of } \\
\text { f-THg) }\end{array}$ & $\begin{array}{l}\text { p-THg } \\
\text { (ng/g) }\end{array}$ & $\begin{array}{c}\text { p-MeHg } \\
(\mathrm{ng} / \mathrm{g})\end{array}$ & $\begin{array}{c}\text { p-MeHg } \\
\text { (\% of } \\
\text { p-THg) }\end{array}$ \\
\hline
\end{tabular}

\section{PHASE I: RECONNAISSANCE SAMPLING}

\begin{tabular}{|c|c|c|c|c|c|c|c|c|c|c|}
\hline CCNP-1 & 20051005 & $12: 20$ & 16.4 & N.D. & 0.61 & N.D. & 3.7 & N.D. & N.D. & N.D. \\
\hline CCNP-2 & 20051005 & $13: 10$ & 10.9 & N.D. & 0.23 & N.D. & 2.1 & N.D. & N.D. & N.D. \\
\hline CCSB-1 & 20051005 & $15: 20$ & 83.7 & N.D. & 0.17 & N.D. & 0.2 & N.D. & N.D. & N.D. \\
\hline YBWA-1 & 20051005 & $17: 00$ & 4.7 & N.D. & 0.71 & N.D. & 15.2 & N.D. & N.D. & N.D. \\
\hline YBWA-2 & 20051005 & $18: 00$ & $5.1^{\mathrm{c}}$ & N.D. & $1.48^{c}$ & N.D. & 29.2 & N.D. & N.D. & N.D. \\
\hline
\end{tabular}

\section{PHASE II: SEASONAL SAMPLING}

\begin{tabular}{|c|c|c|c|c|c|c|c|c|c|c|c|}
\hline CCSB-2 & 20060213 & $11: 20$ & 6.3 & 1.0 & 0.14 & 0.05 & 2.2 & 5.1 & 406 & 6.9 & 1.7 \\
\hline CCSB-2 & 20060530 & $13: 55$ & 76.6 & 0.7 & 0.78 & $<0.04$ & 1.0 & $<5.9$ & 589 & N.D. & N.D. \\
\hline CCSB-3 & 20060213 & $13: 00$ & 7.6 & 1.1 & 0.44 & $<0.04$ & 5.8 & $<3.8$ & 312 & N.D. & N.D. \\
\hline CCSB-3 & 20060530 & $11: 00$ & 12.1 & 0.6 & 0.25 & $<0.04$ & 2.1 & $<6.6$ & 359 & N.D. & N.D. \\
\hline YBWA-1 & 20051031 & $13: 20$ & 3.6 & 1.3 & 0.41 & 0.30 & 11.5 & 22.4 & 224 & 11 & 4.9 \\
\hline YBWA-1 & 20060522 & $13: 15$ & 11.1 & 1.2 & 1.10 & 0.26 & 9.9 & 21.3 & 430 & 37 & 8.5 \\
\hline YBWA-2 & 20051031 & $15: 20$ & 22.9 & 1.9 & 1.72 & 0.78 & 7.5 & 41.9 & 284 & 13 & 4.5 \\
\hline YBWA-2 & 20060522 & $15: 30$ & 16.3 & 2.4 & 1.05 & 0.15 & 6.4 & 6.2 & 289 & 19 & 6.5 \\
\hline YBWA-3 & 20051031 & $16: 40$ & 5.9 & 1.0 & 0.26 & 0.13 & 4.4 & 13.0 & 100 & 2.7 & 2.6 \\
\hline YBWA-4 & 20060522 & $17: 00$ & 12.8 & 2.1 & 0.23 & 0.15 & 1.8 & 7.1 & N.D. & N.D. & N.D. \\
\hline
\end{tabular}

${ }^{\mathrm{a}} \mathrm{p}-\mathrm{THg}=([\mathrm{u}-\mathrm{THg}]-[\mathrm{f}-\mathrm{THg}]) / \mathrm{SSC}$

${ }^{\mathrm{b}} \mathrm{p}-\mathrm{MeHg}=([\mathrm{u}-\mathrm{MeHg}]-[\mathrm{f}-\mathrm{MeHg}]) / \mathrm{SSC} ;$ where $\mathrm{SSC}=$ suspended solids concentration, as given in Table 8

${ }^{c}$ Average of field replicate samples 
Table 4. Data for organic matter in surface water, Cache Creek and Yolo Bypass, Yolo County, California.

[DOC, dissolved organic carbon; POC, particulate organic carbon; SUVA, specific ultraviolet absorption; HPOA, hydrophobic acid; HPIA, hydrophyllic acid; TPIA, transphyllic acid; mg/L, milligram per liter; L/mg-meter, liter per milligram per meter; C, carbon; \%, percentage; N.D., not determined; NWQL, National Water Quality Lab; CWSC, California Water Science Center; NRP, National Research Program]

\begin{tabular}{|c|c|c|c|c|c|c|c|c|c|c|c|c|c|c|c|c|c|}
\hline Site Code & $\begin{array}{c}\text { Collection } \\
\text { Date }\end{array}$ & time & $\begin{array}{c}\text { DOC } \\
\text { [NWOL] } \\
\text { (mg/L as } \\
\text { C) } \\
\end{array}$ & $\begin{array}{c}\text { POC } \\
\text { [NWQL] } \\
\text { (mg/L as } \\
\text { C) }\end{array}$ & $\begin{array}{c}\text { DOC } \\
\text { [CWSC] } \\
\text { (mg/L as } \\
\text { C) } \\
\end{array}$ & $\begin{array}{c}\text { SUVA } \\
\text { [CWSC] } \\
\text { (L/mg-m) }\end{array}$ & $\begin{array}{c}\text { DOC } \\
\text { [NRP] } \\
\text { (mg/L as } \\
\text { C) } \\
\end{array}$ & $\begin{array}{c}\text { SUVA } \\
\text { [NRP] } \\
\text { (L/mg-m) }\end{array}$ & $\begin{array}{c}\text { HPOA } \\
\text { [NRP] } \\
(\%)\end{array}$ & $\begin{array}{l}\text { HPOA } \\
\text { [NRP] } \\
\text { (mg/L) }\end{array}$ & $\begin{array}{c}\text { HPOA } \\
\text { SUVA } \\
\text { [NRP] } \\
\text { (L/mg-m) }\end{array}$ & $\begin{array}{c}\text { HPIA } \\
\text { [NRP] } \\
(\%)\end{array}$ & $\begin{array}{l}\text { HPIA } \\
{[\mathrm{NRP}]} \\
\text { (mg/L) } \\
\end{array}$ & $\begin{array}{c}\text { HPIA } \\
\text { SUVA } \\
\text { [NRP] } \\
\text { (L/mg-m) }\end{array}$ & $\begin{array}{c}\text { TPIA } \\
\text { [NRP] } \\
(\%) \\
\end{array}$ & $\begin{array}{c}\text { TPIA } \\
{[\mathrm{NRP}]} \\
\text { (mg/L) } \\
\end{array}$ & $\begin{array}{c}\text { TPIA } \\
\text { SUVA } \\
\text { [NRP] } \\
(\mathrm{L} / \mathrm{mg}-\mathrm{m}) \\
\end{array}$ \\
\hline \multicolumn{18}{|c|}{ PHASE I: RECONNAISSANCE SAMPLING } \\
\hline CCNP-1 & 20051005 & $12: 20$ & N.D. & N.D. & 6.2 & 2.9 & N.D. & N.D. & N.D. & N.D. & N.D. & N.D. & N.D. & N.D. & N.D. & N.D. & N.D. \\
\hline CCNP-2 & 20051005 & $13: 10$ & N.D. & N.D. & 4.2 & 2.2 & N.D. & N.D. & N.D. & N.D. & N.D. & N.D. & N.D. & N.D. & N.D. & N.D. & N.D. \\
\hline CCSB-1 & 20051005 & $15: 20$ & N.D. & N.D. & 3.2 & 2.4 & N.D. & N.D. & N.D. & N.D. & N.D. & N.D. & N.D. & N.D. & N.D. & N.D. & N.D. \\
\hline YBWA-1 & 20051005 & $17: 00$ & N.D. & N.D. & 8.8 & 2.5 & N.D. & N.D. & N.D. & N.D. & N.D. & N.D. & N.D. & N.D. & N.D. & N.D. & N.D. \\
\hline YBWA-2 & 20051005 & 18:00 & N.D. & N.D. & $5.7^{\mathrm{a}}$ & $3.1^{\mathrm{a}}$ & N.D. & N.D. & N.D. & N.D. & N.D. & N.D. & N.D. & N.D. & N.D. & N.D. & N.D. \\
\hline \multicolumn{18}{|c|}{ PHASE II: SEASONAL SAMPLING } \\
\hline CCSB-2 & 20060213 & $11: 20$ & 2.1 & 1.76 & 2.1 & 2.4 & 2.9 & 1.9 & 33 & 1.0 & 3.1 & N.D. & N.D. & N.D. & N.D. & N.D. & N.D. \\
\hline CCSB-2 & 20060530 & $13: 55$ & 1.7 & 4.73 & 1.6 & 2.6 & 2.4 & 1.9 & 28 & 0.7 & 3.0 & 24 & 0.6 & 1.7 & 15 & 0.4 & 1.8 \\
\hline CCSB-3 & 20060213 & 13:00 & 1.6 & 0.31 & 1.6 & 2.4 & 2.2 & 1.7 & 35 & 0.8 & 3.4 & N.D. & N.D. & N.D. & N.D. & N.D. & N.D. \\
\hline CCSB-3 & 20060530 & $11: 00$ & 1.5 & 1.37 & 1.3 & 2.6 & 2.0 & 1.9 & 30 & 0.6 & 2.7 & N.D. & N.D. & N.D. & 19 & 0.4 & 1.6 \\
\hline YBWA-1 & 20051031 & $13: 20$ & 9.6 & 0.32 & N.D. & N.D. & 10.0 & 1.7 & 33 & 3.3 & 3.1 & 37 & 3.7 & 1.0 & 19 & 1.9 & 1.7 \\
\hline YBWA-1 & 20060522 & $13: 15$ & 5.6 & 9.36 & 4.8 & 2.7 & 6.8 & 1.7 & 30 & 2.0 & 3.6 & 29 & 2.0 & 1.1 & 15 & 1.0 & 2.0 \\
\hline YBWA-2 & 20051031 & $15: 20$ & 6.3 & 0.58 & N.D. & N.D. & 6.7 & 1.7 & 34 & 2.3 & 3.4 & 32 & 2.1 & 1.2 & 17 & 1.1 & 2.0 \\
\hline YBWA-2 & 20060522 & $15: 30$ & 9.3 & 32.30 & 9.6 & 1.9 & 11.6 & 1.7 & 22 & 2.6 & 3.6 & 42 & 4.9 & 0.9 & 11 & 1.3 & 1.9 \\
\hline YBWA-3 & 20051031 & $16: 40$ & 6.0 & 0.24 & N.D. & N.D. & 6.0 & 2.7 & 44 & 2.6 & 3.6 & 33 & 2.0 & 1.1 & 18 & 1.1 & 2.0 \\
\hline YBWA-4 & 20060522 & $17: 00$ & 9.6 & 32.40 & 9.2 & 2.0 & N.D. & N.D. & N.D. & N.D. & N.D. & N.D. & N.D. & N.D. & N.D. & N.D. & N.D. \\
\hline
\end{tabular}

${ }^{a}$ Average of field replicate samples 
Table 5. Data for nutrients and major anions in surface water, study Phase II, Cache Creek and Yolo Bypass, Yolo County, California.

[filt., filtered; unfilt., unfiltered; part., particulate; $\mathrm{NH}_{4}{ }^{+}$, ammonium; $\mathrm{N}$-org.; organic nitrogen; $\mathrm{NO}_{2}{ }^{-}$, nitrite; $\mathrm{NO}_{2}{ }^{-}$, nitrate; $\mathrm{N}$-Total, total nitrogen; $\mathrm{P}$-Total, total phosphorus; $\mathrm{PO}_{4}{ }^{3-}$; orthophosphate; $\mathrm{Cl}^{-}$, chloride; $\mathrm{SO}_{4}{ }^{2-}$, sulfate; $\mathrm{mg} / \mathrm{L}$, milligram per liter; $\mathrm{N}$, nitrogen; $\mathrm{P}$, phosphorus; N.D., not determined; <, less than; $\mathrm{E}$, estimated; 5-digit number after each constituent indicates U.S. Geological Survey National Water Quality Laboratory parameter code]

\begin{tabular}{|c|c|c|c|c|c|c|c|c|c|c|c|c|c|}
\hline Site Code & $\begin{array}{l}\text { Collection } \\
\text { Date }\end{array}$ & time & $\begin{array}{c}\mathrm{NH}_{4}{ }^{+} \text {, } \\
\text { filt. } \\
\text { (mg/L } \\
\text { as N) } \\
00608\end{array}$ & $\begin{array}{c}\mathrm{NH}_{4}{ }^{+} \\
\text {plus } \\
\mathrm{N} \text {-org., } \\
\text { filt. } \\
\text { (mg/L } \\
\text { as N) } \\
\mathbf{0 0 6 2 3}\end{array}$ & $\begin{array}{c}\mathrm{NH}_{4}^{+} \\
\text {plus } \\
\mathrm{N}- \\
\text { org., } \\
\text { unfilt. } \\
\text { (mg/L } \\
\text { as } \mathrm{N} \text { ) } \\
\mathbf{0 0 6 2 5}\end{array}$ & $\begin{array}{c}\mathrm{NO}_{2}^{-} \\
\text {plus } \\
\mathrm{NO}_{3}^{-} \text {, } \\
\text { filt. } \\
\text { (mg/L } \\
\text { as N) } \\
\mathbf{0 0 6 3 1}\end{array}$ & $\begin{array}{c}\mathrm{NO}_{2} \\
\text { filt. } \\
\text { (mg/L } \\
\text { as N) } \\
00613\end{array}$ & $\begin{array}{c}\text { N- } \\
\text { Total, } \\
\text { part. } \\
\text { (mg/L) } \\
49570\end{array}$ & $\begin{array}{c}\text { P- } \\
\text { Total, } \\
\text { filt. } \\
\text { (mg/L } \\
\text { as P) } \\
\mathbf{0 0 6 6 6}\end{array}$ & $\begin{array}{c}\mathrm{PO}_{4}{ }^{3-} \text {, } \\
\text { filt. } \\
\text { (mg/L } \\
\text { as P) } \\
00671\end{array}$ & $\begin{array}{c}\text { P- } \\
\text { Total, } \\
\text { unfilt. } \\
\text { (mg/L } \\
\text { as P) } \\
\mathbf{0 0 6 6 5}\end{array}$ & $\begin{array}{c}\mathrm{Cl}^{\prime} \\
\text { filt. } \\
\text { (mg/L) }\end{array}$ & $\begin{array}{c}\mathrm{SO}_{4}{ }^{2-}{ }^{2} \\
\text { filt. } \\
\text { (mg/L) }\end{array}$ \\
\hline CCSB-2 & 20060213 & $11: 20$ & 0.04 & 0.3 & 0.7 & 0.662 & 0.008 & 0.371 & 0.02 & $<0.02$ & 0.06 & 32 & 25 \\
\hline CCSB-2 & 20060530 & $13: 55$ & N.D. & 0.2 & 1.2 & 4.13 & N.D. & 0.878 & 0.012 & 0.011 & 0.11 & 44 & 38 \\
\hline CCSB-3 & 20060213 & 13:00 & $<0.04$ & 0.1 & 0.2 & 1.16 & E 0.004 & 0.083 & 0.015 & E 0.01 & 0.05 & 35 & 27 \\
\hline CCSB-3 & 20060530 & $11: 00$ & N.D. & 0.2 & 0.5 & 4.87 & N.D. & 0.255 & $<0.004$ & 0.008 & 0.05 & 46 & 39 \\
\hline YBWA-1 & 20051031 & $13: 20$ & $<0.04$ & 0.7 & 0.8 & $<0.060$ & $<0.008$ & $<0.022$ & 0.20 & 0.16 & 0.21 & 101 & 92 \\
\hline YBWA-1 & 20060522 & $13: 15$ & $<0.04$ & 0.4 & 2.1 & $<0.060$ & $<0.008$ & 2.00 & 0.040 & E 0.01 & 0.34 & 18 & 12 \\
\hline YBWA-2 & 20051031 & $15: 20$ & $<0.04$ & 0.6 & 2.7 & 0.445 & 0.010 & 0.062 & 0.29 & 0.26 & 0.93 & 51 & 60 \\
\hline YBWA-2 & 20060522 & $15: 30$ & 0.07 & 0.9 & 7.6 & $<0.060$ & $<0.008$ & 7.00 & 0.046 & $<0.02$ & 0.59 & 20 & 23 \\
\hline YBWA-3 & 20051031 & $16: 40$ & 0.10 & 0.6 & 0.8 & 0.786 & 0.010 & $<0.022$ & 0.33 & 0.31 & 0.38 & 49 & 60 \\
\hline YBWA-4 & 20060522 & $17: 00$ & 0.06 & 0.9 & 8.7 & $<0.060$ & $<0.008$ & 7.03 & 0.047 & $<0.02$ & 0.66 & 21 & 24 \\
\hline
\end{tabular}


Table 6. Data for major cations and trace elements in filtered surface water, study Phase II, Cache Creek Settling Basin and Yolo Bypass, Yolo County, California.

$[\mu \mathrm{g} / \mathrm{L}$, microgram per liter; mg/L, milligram per liter; analytical error based upon replicate $(\mathrm{n}=2)$ measurements is given in parentheses $(\quad)$; measurements below the analytical detection limit are indicated with ' $<$ ' and the method limit; See front matter for explanation of chemical symbols.]

\begin{tabular}{|c|c|c|c|c|c|c|c|c|}
\hline $\begin{array}{l}\text { Site } \\
\text { Code }\end{array}$ & $\begin{array}{c}\text { Collection } \\
\text { Date }\end{array}$ & $\begin{array}{c}\mathrm{Al} \\
\mu \mathrm{g} / \mathrm{L}\end{array}$ & $\begin{array}{c}\text { As } \\
\mu g / L\end{array}$ & $\begin{array}{c}\text { B } \\
\mu g / L\end{array}$ & $\begin{array}{c}\mathrm{Ba} \\
\mu \mathrm{g} / \mathrm{L}\end{array}$ & $\begin{array}{c}\mathrm{Be} \\
\mu \mathrm{g} / \mathrm{L}\end{array}$ & $\begin{array}{c}\mathrm{Bi} \\
\mu \mathrm{g} / \mathrm{L}\end{array}$ & $\begin{array}{c}\mathrm{Ca} \\
\mathrm{mg} / \mathrm{L}\end{array}$ \\
\hline CCSB-2 & 20060213 & $3.8(0.1)$ & $1.4(0.0)$ & $1020(24)$ & $97(2)$ & $<0.01$ & $<0.002$ & $35(1)$ \\
\hline CCSB-2 & 20060530 & $1.4(0.3)$ & $1.7(0.0)$ & $1705(10)$ & $172(1)$ & $<0.004$ & $<0.003$ & $47(0)$ \\
\hline CCSB-3 & 20060213 & $4.7(0.1)$ & $1.2(0.0)$ & $1010(6)$ & $94(2)$ & $<0.01$ & $<0.002$ & $33(0)$ \\
\hline CCSB-3 & 20060530 & $1.3(0.1)$ & $1.3(0.0)$ & $1740(6)$ & $160(2)$ & $<0.004$ & $0.0014(0.0007)$ & $49(0)$ \\
\hline YBWA-1 & 20051031 & $3.6(0.2)$ & $9.6(0.1)$ & $1640(54)$ & $35(0)$ & $<0.008$ & $0.0016(0.0004)$ & $50(0)$ \\
\hline YBWA-1 & 20060522 & $0.8(0.3)$ & $6.4(0.1)$ & $383(1)$ & $50(1)$ & $<0.004$ & $0.0025(0.0010)$ & $29(0)$ \\
\hline YBWA-2 & 20051031 & $3.0(0.2)$ & $5.0(0.0)$ & $732(36)$ & $78(0)$ & $<0.010$ & $0.0023(0.0002)$ & $34(0)$ \\
\hline YBWA-2 & 20060522 & $2.4(0.2)$ & $7.8(0.1)$ & $468(7)$ & $36(0)$ & $<0.004$ & $0.0023(0.0011)$ & $20(0)$ \\
\hline YBWA-3 & 20051031 & $2.7(0.1)$ & $4.7(0.0)$ & $692(11)$ & $83(1)$ & $<0.008$ & $0.0033(0.0003)$ & $34(0)$ \\
\hline YBWA-4 & 20060522 & $2.8(0.0)$ & $8.1(0.1)$ & $470(11)$ & $30(1)$ & $<0.004$ & $0.0043(0.0030)$ & $19(0)$ \\
\hline $\begin{array}{l}\text { Site } \\
\text { Code }\end{array}$ & $\begin{array}{c}\text { Collection } \\
\text { Date }\end{array}$ & $\begin{array}{c}\text { Cd } \\
\mu \mathrm{g} / \mathrm{L}\end{array}$ & $\begin{array}{c}\mathrm{Ce} \\
\mu \mathrm{g} / \mathrm{L}\end{array}$ & $\begin{array}{c}\text { Co } \\
\mu g / L\end{array}$ & $\begin{array}{c}\mathrm{Cr} \\
\mu \mathrm{g} / \mathrm{L}\end{array}$ & $\begin{array}{c}\text { Cs } \\
\mu g / L\end{array}$ & $\begin{array}{c}\mathrm{Cu} \\
\mu \mathrm{g} / \mathrm{L}\end{array}$ & $\begin{array}{c}\text { Dy } \\
\mu g / L\end{array}$ \\
\hline CCSB-2 & 20060213 & $<0.003$ & $0.008(0.001)$ & $0.19(0.00)$ & $1.2(0.0)$ & $<0.01$ & $3.0(0.1)$ & $0.0031(0.0004)$ \\
\hline CCSB-2 & 20060530 & $<0.002$ & $0.019(0.001)$ & $0.26(0.00)$ & $1.7(0.0)$ & $<0.01$ & $1.4(0.0)$ & $0.0094(0.0008)$ \\
\hline CCSB-3 & 20060213 & $0.002(0.0005)$ & $0.007(0.000)$ & $0.05(0.00)$ & $1.5(0.0)$ & $<0.01$ & $0.89(0.08)$ & $0.0032(0.0004)$ \\
\hline CCSB-3 & 20060530 & $0.003(0.0013)$ & $0.011(0.001)$ & $0.10(0.00)$ & $2.5(0.1)$ & $<0.01$ & $1.1(0.0)$ & $0.0081(0.0002)$ \\
\hline YBWA-1 & 20051031 & $<0.002$ & $0.034(0.000)$ & $0.22(0.00)$ & $0.70(0.02)$ & $<0.001$ & $1.0(0.2)$ & $0.0152(0.0011)$ \\
\hline YBWA-1 & 20060522 & $0.003(0.0008)$ & $0.011(0.000)$ & $0.23(0.01)$ & $0.39(0.02)$ & $<0.01$ & $0.71(0.02)$ & $0.0032(0.0003)$ \\
\hline YBWA-2 & 20051031 & $0.005(0.0008)$ & $0.013(0.000)$ & $0.34(0.00)$ & $0.68(0.03)$ & $<0.001$ & $1.1(0.1)$ & $0.0048(0.0004)$ \\
\hline YBWA-2 & 20060522 & $0.011(0.0012)$ & $0.035(0.001)$ & $0.45(0.01)$ & $0.46(0.02)$ & $<0.01$ & $4.1(0.0)$ & $0.0084(0.0002)$ \\
\hline YBWA-3 & 20051031 & $0.005(0.0013)$ & $0.013(0.001)$ & $0.19(0.00)$ & $0.69(0.04)$ & $<0.003$ & $1.7(0.1)$ & $0.0072(0.0005)$ \\
\hline YBWA-4 & 20060522 & $0.010(0.0020)$ & $0.024(0.001)$ & $0.41(0.00)$ & $0.44(0.02)$ & $<0.01$ & $3.9(0.0)$ & $0.0058(0.0001)$ \\
\hline
\end{tabular}


Table 6. Continued

\begin{tabular}{|c|c|c|c|c|c|c|c|c|}
\hline $\begin{array}{l}\text { Site } \\
\text { Code }\end{array}$ & $\begin{array}{c}\text { Collection } \\
\text { Date }\end{array}$ & $\begin{array}{c}\mathrm{Er} \\
\mu \mathrm{g} / \mathrm{L}\end{array}$ & $\begin{array}{c}\text { Eu } \\
\mu g / L\end{array}$ & $\begin{array}{c}\text { Fe } \\
\mu g / L\end{array}$ & $\begin{array}{r}\text { Gd } \\
\mu g / L\end{array}$ & $\begin{array}{r}\mathrm{Ho} \\
\mu \mathrm{g} / \mathrm{L}\end{array}$ & $\begin{array}{c}\mathrm{K} \\
\mathrm{mg} / \mathrm{L}\end{array}$ & $\begin{array}{c}\text { La } \\
\mu \mathrm{g} / \mathrm{L}\end{array}$ \\
\hline CCSB-2 & 20060213 & $0.0033(0.0003)$ & $<0.0002$ & $<3$ & $0.00278(0.000)$ & $0.0009(0.0001)$ & $2.0(0.1)$ & $0.0061(0.0003)$ \\
\hline CCSB-2 & 20060530 & $0.0071(0.0002)$ & $0.0015(0.0009)$ & $7(6)$ & $0.00648(0.000)$ & $0.0023(0.0001)$ & $2.6(0.1)$ & $0.0120(0.0002)$ \\
\hline CCSB-3 & 20060213 & $0.0024(0.0002)$ & $<0.0002$ & 32 (19) & $0.00239(0.000)$ & $0.0008(0.0001)$ & $1.8(0.0)$ & $0.0054(0.0001)$ \\
\hline CCSB-3 & 20060530 & $0.0058(0.0003)$ & $0.0013(0.0004)$ & $<3$ & $0.00496(0.000)$ & $0.0021 \quad(0.0001)$ & $2.5(0.0)$ & $0.0095(0.0001)$ \\
\hline YBWA-1 & 20051031 & $0.0096(0.0008)$ & $0.0031(0.0005)$ & $25(2)$ & $0.01307(0.000)$ & $0.0032(0.0000)$ & $4.3(0.0)$ & $0.0183(0.0004)$ \\
\hline YBWA-1 & 20060522 & $0.0025(0.0005)$ & $0.0011(0.0003)$ & $26(2)$ & $0.00292(0.000)$ & $0.0007(0.0001)$ & $2.4(0.0)$ & $0.0083(0.0003)$ \\
\hline YBWA-2 & 20051031 & $0.0038(0.0005)$ & $<0.0020$ & $29(3)$ & $0.00887(0.001)$ & $0.0014(0.0000)$ & $4.7(0.1)$ & $0.0083(0.0004)$ \\
\hline YBWA-2 & 20060522 & $0.0050(0.0003)$ & $0.0019(0.0001)$ & $42(1)$ & $0.00872(0.000)$ & $0.0016(0.0002)$ & $2.0(0.1)$ & $0.0189(0.0003)$ \\
\hline YBWA-3 & 20051031 & $0.0046(0.0003)$ & $0.0017(0.0009)$ & $24(3)$ & $0.01128(0.001)$ & $0.0017(0.0000)$ & $4.6(0.1)$ & $0.0107(0.0004)$ \\
\hline YBWA-4 & 20060522 & $0.0039(0.0003)$ & $0.0014(0.0003)$ & $43(5)$ & $0.00592(0.000)$ & $0.0012(0.0001)$ & $2.0(0.0)$ & $0.0139(0.0004)$ \\
\hline $\begin{array}{l}\text { Site } \\
\text { Code }\end{array}$ & $\begin{array}{c}\text { Collection } \\
\text { Date }\end{array}$ & $\begin{array}{c}\mathrm{Li} \\
\mu \mathrm{g} / \mathrm{L}\end{array}$ & $\begin{array}{c}\mathrm{Lu} \\
\mu \mathrm{g} / \mathrm{L}\end{array}$ & $\begin{array}{r}\mathrm{Mg} \\
\mathrm{mg} / \mathrm{L}\end{array}$ & $\begin{array}{c}\text { Mn } \\
\mu g / L\end{array}$ & $\begin{array}{r}\text { Mo } \\
\mu g / L\end{array}$ & $\begin{array}{c}\mathrm{Na} \\
\mathrm{mg} / \mathrm{L}\end{array}$ & $\begin{array}{c}\text { Nd } \\
\mu g / L\end{array}$ \\
\hline CCSB-2 & 20060213 & $36(1)$ & $0.0003(0.0000)$ & $28(1)$ & $81(3)$ & $0.52(0.01)$ & $30(1)$ & $0.0082(0.0004)$ \\
\hline CCSB-2 & 20060530 & $40(0)$ & $0.0008(0.0001)$ & $40(0)$ & $129(1)$ & $0.68(0.02)$ & $45(0)$ & $0.018(0.001)$ \\
\hline CCSB-3 & 20060213 & $37(0)$ & $0.0004(0.0001)$ & $27(0)$ & $6.3(0.1)$ & $0.47(0.02)$ & $32(0)$ & $0.0077(0.0002)$ \\
\hline CCSB-3 & 20060530 & $42(0)$ & $0.0008(0.0001)$ & $41(1)$ & $3.7(0.0)$ & $0.59(0.01)$ & $47(1)$ & $0.016(0.000)$ \\
\hline YBWA-1 & 20051031 & $17(0)$ & $0.0016(0.0001)$ & $45(0)$ & 107 (1) & $3.6(0.0)$ & $103(2)$ & $0.034(0.001)$ \\
\hline YBWA-1 & 20060522 & $7.9(0.1)$ & $0.0004(0.0001)$ & $20(0)$ & $140(2)$ & $0.66(0.01)$ & $28(0)$ & $0.0098(0.0007)$ \\
\hline YBWA-2 & 20051031 & $13(0)$ & $0.0006(0.0001)$ & $28(0)$ & $29(0)$ & $3.1(0.0)$ & $73(1)$ & $0.012(0.001)$ \\
\hline YBWA-2 & 20060522 & $7.9(0.1)$ & $0.0007(0.0000)$ & $18(0)$ & $3.3(0.1)$ & $1.2(0.0)$ & $31(0)$ & $0.029(0.000)$ \\
\hline YBWA-3 & 20051031 & $14(0)$ & $0.0006(0.0001)$ & $28(0)$ & $1.5(0.0)$ & $3.1(0.0)$ & $68(1)$ & $0.017(0.001)$ \\
\hline YBWA-4 & 20060522 & $8.2(0.1)$ & $0.0005(0.0000)$ & $18(0)$ & $3.3(0.1)$ & $1.1(0.0)$ & $32(0)$ & $0.021(0.001)$ \\
\hline
\end{tabular}


Table 6. Continued

\begin{tabular}{|c|c|c|c|c|c|c|c|c|}
\hline $\begin{array}{l}\text { Site } \\
\text { Code }\end{array}$ & $\begin{array}{c}\text { Collection } \\
\text { Date }\end{array}$ & $\begin{array}{c}\mathrm{Ni} \\
\mu \mathrm{g} / \mathrm{L}\end{array}$ & $\begin{array}{r}\mathbf{P b} \\
\mu \mathrm{g} / \mathrm{L}\end{array}$ & $\begin{array}{c}\mathrm{Pr} \\
\mu \mathrm{g} / \mathrm{L}\end{array}$ & $\begin{array}{r}\mathbf{R b} \\
\mu \mathrm{g} / \mathrm{L}\end{array}$ & $\begin{array}{c}R e \\
\mu g / L \\
\end{array}$ & $\begin{array}{c}\mathrm{S} \\
\mathrm{mg} / \mathrm{L}\end{array}$ & $\begin{array}{c}\mathrm{Sb} \\
\mu \mathrm{g} / \mathrm{L}\end{array}$ \\
\hline CCSB-2 & 20060213 & $2.7(0.0)$ & $0.029(0.002)$ & $0.0014(0.0001)$ & $0.87(0.00)$ & $0.0027(0.0003)$ & $11(0)$ & $0.14(0.00)$ \\
\hline CCSB-2 & 20060530 & $2.6(0.0)$ & $0.026(0.001)$ & $0.0032(0.0002)$ & $0.79(0.01)$ & $0.0059(0.0005)$ & $14(0)$ & $0.23(0.00)$ \\
\hline CCSB-3 & 20060213 & $1.6(0.0)$ & $0.027(0.001)$ & $0.0013(0.0001)$ & $0.83(0.01)$ & $0.0022(0.0001)$ & $11(0)$ & $0.13(0.00)$ \\
\hline CCSB-3 & 20060530 & $1.8(0.0)$ & $0.025(0.003)$ & $0.0028(0.0003)$ & $0.84(0.02)$ & $0.0058(0.0004)$ & $15(0)$ & $0.17(0.00)$ \\
\hline YBWA-1 & 20051031 & $6.1(0.1)$ & $0.115(0.024)$ & $0.0063(0.0003)$ & $0.28(0.01)$ & $0.0058(0.0003)$ & $36(0)$ & $0.26(0.00)$ \\
\hline YBWA-1 & 20060522 & $2.1(0.0)$ & $0.030(0.006)$ & $0.0017(0.0001)$ & $0.63(0.01)$ & $0.0025(0.0004)$ & $4.5(0.0)$ & $0.16(0.00)$ \\
\hline YBWA-2 & 20051031 & $3.9(0.0)$ & $0.075(0.012)$ & $0.0022(0.0001)$ & $0.91(0.02)$ & $0.0045(0.0005)$ & $23(0)$ & $0.21(0.00)$ \\
\hline YBWA-2 & 20060522 & $2.1(0.0)$ & $0.053(0.003)$ & $0.0056(0.0002)$ & $0.45(0.01)$ & $0.0030(0.0001)$ & $9.1(0.1)$ & $0.34(0.00)$ \\
\hline YBWA-3 & 20051031 & $3.8(0.0)$ & $0.064(0.005)$ & $0.0031(0.0001)$ & $0.99(0.01)$ & $0.0045(0.0004)$ & $24(1)$ & $0.20(0.01)$ \\
\hline YBWA-4 & 20060522 & $1.8(0.0)$ & $0.043(0.007)$ & $0.0040(0.0003)$ & $0.57(0.03)$ & $0.0033(0.0004)$ & $9.2(0.1)$ & $0.31(0.00)$ \\
\hline $\begin{array}{l}\text { Site } \\
\text { Code }\end{array}$ & $\begin{array}{c}\text { Collection } \\
\text { Date }\end{array}$ & $\begin{array}{c}\mathrm{Se} \\
\mu \mathrm{g} / \mathrm{L}\end{array}$ & $\begin{array}{c}\mathrm{SiO}_{2} \\
\mathrm{mg} / \mathrm{L}\end{array}$ & $\begin{array}{c}\mathrm{Sm} \\
\mu \mathrm{g} / \mathrm{L}\end{array}$ & $\begin{array}{c}\mathrm{Sr} \\
\mu \mathrm{g} / \mathrm{L}\end{array}$ & $\begin{array}{c}\mathrm{Tb} \\
\mu \mathrm{g} / \mathrm{L}\end{array}$ & $\begin{array}{c}\mathrm{Te} \\
\mu \mathrm{g} / \mathrm{L}\end{array}$ & $\begin{array}{c}\mathrm{Tl} \\
\mu \mathrm{g} / \mathrm{L}\end{array}$ \\
\hline CCSB-2 & 20060213 & $0.13(0.01)$ & $17(0)$ & $0.0025(0.0002)$ & $371(1)$ & $0.0004(0.0000)$ & $0.006(0.002)$ & $0.03(0.01)$ \\
\hline CCSB-2 & 20060530 & $0.58(0.02)$ & $16(0)$ & $0.0055(0.0002)$ & $554(10)$ & $0.0012(0.0001)$ & $<0.006$ & $<0.01$ \\
\hline CCSB-3 & 20060213 & $0.10(0.00)$ & $15(0)$ & $0.0022(0.0004)$ & $363(1)$ & $0.0006(0.0001)$ & $0.007(0.002)$ & $0.00(0.00)$ \\
\hline CCSB-3 & 20060530 & $0.60(0.02)$ & $16(0)$ & $0.0050(0.0003)$ & $568(6)$ & $0.0011(0.0001)$ & $<0.006$ & $<0.02$ \\
\hline YBWA-1 & 20051031 & $0.36(0.01)$ & $11(0)$ & $0.0093(0.0007)$ & $586(1)$ & $0.0023(0.0001)$ & $0.029(0.002)$ & $0.012(0.01)$ \\
\hline YBWA-1 & 20060522 & $<0.05$ & $16(0)$ & $0.0031(0.0004)$ & $288(4)$ & $0.0005(0.0001)$ & $0.028(0.006)$ & $<0.05$ \\
\hline YBWA-2 & 20051031 & $0.44(0.02)$ & $16(0)$ & $0.0035(0.0003)$ & $431(1)$ & $0.0006(0.0001)$ & $0.014(0.001)$ & $0.011(0.01)$ \\
\hline YBWA-2 & 20060522 & $0.06(0.00)$ & $8.7(0.1)$ & $0.0074(0.0004)$ & $219(3)$ & $0.0014(0.0001)$ & $0.023(0.003)$ & $<0.01$ \\
\hline YBWA-3 & 20051031 & $0.49(0.02)$ & $19(1)$ & $0.0051(0.0008)$ & $424(3)$ & $0.0010(0.0001)$ & $0.012(0.002)$ & $0.017(0.008)$ \\
\hline YBWA-4 & 20060522 & $<0.06$ & $8.9(0.1)$ & $0.0061(0.0003)$ & $221(2)$ & $0.0009(0.0001)$ & $0.027(0.003)$ & $<0.01$ \\
\hline
\end{tabular}


Table 6. Continued

\begin{tabular}{|c|c|c|c|c|c|c|c|c|}
\hline $\begin{array}{l}\text { Site } \\
\text { Code }\end{array}$ & $\begin{array}{c}\text { Collection } \\
\text { Date }\end{array}$ & $\begin{array}{c}\mathrm{Tm} \\
\mu \mathrm{g} / \mathrm{L}\end{array}$ & $\begin{array}{c}\mathrm{U} \\
\mu \mathrm{g} / \mathrm{L}\end{array}$ & $\begin{array}{c}V \\
\mu g / L\end{array}$ & $\begin{array}{c}W \\
\mu g / L\end{array}$ & $\begin{array}{c}Y \\
\mu g / L\end{array}$ & $\begin{array}{c}\mathrm{Yb} \\
\mu \mathrm{g} / \mathrm{L}\end{array}$ & $\begin{array}{c}\mathrm{Zn} \\
\mu \mathrm{g} / \mathrm{L}\end{array}$ \\
\hline CCSB-2 & 20060213 & $0.0004(0.0001)$ & $0.21(0.00)$ & $1.7(0.0)$ & $0.94(0.01)$ & $0.041(0.001)$ & $0.0025(0.0001)$ & $0.9(0.4)$ \\
\hline CCSB-2 & 20060530 & $0.0009(0.0001)$ & $0.62(0.01)$ & $4.1(0.0)$ & $0.48(0.00)$ & $0.11(0.00)$ & $0.0060(0.0001)$ & $<0.2$ \\
\hline CCSB-3 & 20060213 & $0.0004(0.0001)$ & $0.22(0.00)$ & $1.6(0.0)$ & $1.1(0.0)$ & $0.036(0.001)$ & $0.0023(0.0001)$ & $0.25(0.0)$ \\
\hline CCSB-3 & 20060530 & $0.0009(0.0000)$ & $0.65(0.01)$ & $2.6(0.0)$ & $0.41(0.00)$ & $0.095(0.001)$ & $0.0044(0.0003)$ & $<0.2$ \\
\hline YBWA-1 & 20051031 & $0.0012(0.0001)$ & $1.3(0.0)$ & $8.8(0.1)$ & $0.16(0.00)$ & $0.14(0.00)$ & $0.0089(0.0001)$ & $0.82(0.1)$ \\
\hline YBWA-1 & 20060522 & $0.0003(0.0001)$ & $0.38(0.01)$ & $2.7(0.0)$ & $0.087(0.002)$ & $0.028(0.000)$ & $0.0025(0.0002)$ & $0.7(0.1)$ \\
\hline YBWA-2 & 20051031 & $0.0006(0.0000)$ & $0.92(0.02)$ & $6.1(0.0)$ & $0.12(0.00)$ & $0.049(0.000)$ & $0.0041(0.0003)$ & $1.6(0.1)$ \\
\hline YBWA-2 & 20060522 & $0.0006(0.0000)$ & $0.93(0.01)$ & $14(0)$ & $0.20(0.00)$ & $0.068(0.001)$ & $0.0040(0.0003)$ & $0.5(0.0)$ \\
\hline YBWA-3 & 20051031 & $0.0006(0.0001)$ & $0.91(0.05)$ & $5.4(0.0)$ & $0.10(0.00)$ & $0.058(0.001)$ & $0.0040(0.0001)$ & $1.3(0.0)$ \\
\hline YBWA-4 & 20060522 & $0.0004(0.0001)$ & $0.89(0.01)$ & $13(0)$ & $0.16(0.00)$ & $0.045(0.001)$ & $0.0028(0.0002)$ & $<0.2$ \\
\hline
\end{tabular}

\begin{tabular}{ccc}
\hline $\begin{array}{c}\text { Site } \\
\text { Code }\end{array}$ & $\begin{array}{c}\text { Collection } \\
\text { Date }\end{array}$ & $\begin{array}{c}\mathbf{Z r} \\
\boldsymbol{\mu g} / \mathbf{L}\end{array}$ \\
\hline CCSB-2 & 20060213 & $0.074(0.010)$ \\
CCSB-2 & 20060530 & $0.075(0.032)$ \\
CCSB-3 & 20060213 & $0.054(0.023)$ \\
CCSB-3 & 20060530 & $0.054(0.018)$ \\
YBWA-1 & 20051031 & $0.057(0.003)$ \\
YBWA-1 & 20060522 & $0.043(0.004)$ \\
YBWA-2 & 20051031 & $0.076(0.003)$ \\
YBWA-2 & 20060522 & $0.056(0.009)$ \\
YBWA-3 & 20051031 & $0.040(0.006)$ \\
YBWA-4 & 20060522 & $0.098(0.032)$ \\
\hline
\end{tabular}


Table 7. Data for stable isotopes of oxygen in water and sulfur in sulfate in surface water, study Phase II, Cache Creek and Yolo Bypass, Yolo County, California.

$\left[\delta^{18} \mathrm{O}\right.$ in $\mathrm{H}_{2} \mathrm{O}$, oxygen isotope ratio $\left.{ }^{18} \mathrm{O} /{ }^{16} \mathrm{O}\right)$ in unfiltered water relative to the VSMOW standard; $\delta^{34} \mathrm{~S}$ in $\mathrm{SO}_{4}{ }^{2-}$, sulfur isotope ratio ${ }^{34} \mathrm{~S} /{ }^{32} \mathrm{~S}$ ) in filter-passing (less than 0.45 micrometer fraction) sulfate relative to the VCDT standard; per mill, part per thousand; VSMOW, Vienna Standard Mean Ocean Water; VCDT, Vienna Cañon Diablo Troilite; analytical error based upon replicate $(n=2)$ measurements is given in parentheses ( ), when no error is expressed the number of analytical measurements was 1; N.D., not determined]

\begin{tabular}{|c|c|c|c|c|}
\hline Site Code & $\begin{array}{c}\text { Collection } \\
\text { Date }\end{array}$ & time & $\begin{array}{c}\delta^{18} 0 \text { in } \mathrm{H}_{2} \mathrm{O}, \\
\text { per mill, } \\
\text { VSMOW }\end{array}$ & $\begin{array}{c}\delta^{34} \mathrm{~S} \text { in } \mathrm{SO}_{4}{ }^{2-} \\
\text { per mill, VCDT }\end{array}$ \\
\hline CCSB-2 & 20060213 & $11: 20$ & -6.1 & -1.1 \\
\hline CCSB-2 & 20060530 & $13: 55$ & -5.7 & -0.3 \\
\hline CCSB-3 & 20060213 & $13: 00$ & -6.9 & -1.6 \\
\hline CCSB-3 & 20060530 & 11:00 & $-5.7(0.0)$ & -0.3 \\
\hline YBWA-1 & 20051031 & $13: 20$ & -3.1 & 5.7 \\
\hline YBWA-1 & 20060522 & $13: 15$ & -6.6 & $3.9(0.1)$ \\
\hline YBWA-2 & 20051031 & $15: 20$ & -7.5 & 2.2 \\
\hline YBWA-2 & 20060522 & $15: 30$ & -3.9 & $1.7(0.1)$ \\
\hline YBWA-3 & 20051031 & $16: 40$ & -7.7 & -1.4 \\
\hline YBWA-4 & 20060522 & $17: 00$ & -3.8 & 1.6 \\
\hline
\end{tabular}


Table 8. Ancillary surface water data, Cache Creek and Yolo Bypass, Yolo County, California.

[Temp., temperature; ${ }^{\circ} \mathrm{C}$, degrees Celsius; D.O., dissolved oxygen; S.C., specific conductance; $\mu \mathrm{S} / \mathrm{cm}$, microSiemen per centimeter; SSC, suspended sediment concentration; < $63 \mu \mathrm{m}$, SSC less than 63 micrometers; \%, percentage; N.D., not determined]

\begin{tabular}{|c|c|c|c|c|c|c|c|c|c|c|c|}
\hline Site Code & $\begin{array}{l}\text { Collection } \\
\text { Date }\end{array}$ & Time & $\begin{array}{l}\text { Temp. } \\
\left({ }^{\circ} \mathrm{C}\right)\end{array}$ & $\begin{array}{l}\text { D.0. } \\
(\%)\end{array}$ & $\begin{array}{c}\mathrm{pH} \\
\text { (field) }\end{array}$ & $\underset{\text { (lab) }}{\mathrm{pH}}$ & $\begin{array}{c}\text { S,C. } \\
(\mu \mathrm{S} / \mathrm{cm}) \\
\text { (field) }\end{array}$ & $\begin{array}{c}\text { S.C. } \\
(\mu \mathrm{S} / \mathrm{cm}) \\
(\mathrm{lab})\end{array}$ & $\begin{array}{c}\text { Alkalinity } \\
\text { (mg/L as } \\
\text { CaCO } \\
\text { (lab) }\end{array}$ & $\begin{array}{c}\text { SSC } \\
(\mathrm{mg} / \mathrm{L})\end{array}$ & $\begin{array}{c}<63 \mu \mathrm{m} \\
(\%)\end{array}$ \\
\hline \multicolumn{12}{|c|}{ PHASE I: RECONNAISSANCE SAMPLING } \\
\hline CCNP-1 & 20051005 & $12: 20$ & 18.0 & N.D. & N.D. & 8.35 & N.D. & 1088 & N.D. & N.D. & N.D. \\
\hline CCNP-2 & 20051005 & 13:10 & $18-19$ & N.D. & N.D. & 8.42 & N.D. & 845 & N.D. & N.D. & N.D. \\
\hline CCSB-1 & 20051005 & 15:20 & 21.0 & N.D. & N.D. & 8.57 & N.D. & 679 & N.D. & N.D. & N.D. \\
\hline YBWA-1 & 20051005 & 17:00 & 19.0 & N.D. & N.D. & 8.36 & N.D. & 1004 & N.D. & N.D. & N.D. \\
\hline YBWA-2 & 20051005 & 18:00 & N.D. & N.D. & N.D. & 8.31 & N.D. & 680 & N.D. & N.D. & N.D. \\
\hline \multicolumn{12}{|c|}{ PHASE II: SEASONAL SAMPLING } \\
\hline CCSB-2 & 20060213 & $11: 20$ & 12.0 & N.D. & 8.10 & N.D. & 570 & N.D. & N.D. & 13 & 92.5 \\
\hline CCSB-2 & 20060530 & 13:55 & 22.8 & 109 & 8.10 & 8.20 & 431 & 517 & N.D. & 129 & 98.8 \\
\hline CCSB-3 & 20060213 & 13:00 & 14.0 & N.D. & 8.10 & N.D. & 592 & N.D. & N.D. & 21 & 97.2 \\
\hline CCSB-3 & 20060530 & $11: 00$ & 22.1 & 99 & 8.10 & 8.40 & 409 & 521 & N.D. & 32 & 97.9 \\
\hline YBWA-1 & 20051031 & $13: 20$ & 17.1 & 177 & 8.68 & 8.65 & 1248 & 980 & 323 & 10 & 83.8 \\
\hline YBWA-1 & 20060522 & $13: 15$ & 20.2 & 163 & 7.74 & 7.95 & 435 & 315 & N.D. & 23 & 96.7 \\
\hline YBWA-2 & 20051031 & $15: 20$ & 18.2 & 117 & 8.22 & 8.05 & 904 & 670 & 227 & 74 & 87.7 \\
\hline YBWA-2 & 20060522 & $15: 30$ & 22.7 & 222 & 9.46 & 9.53 & 402 & 279 & N.D. & 48 & 98.4 \\
\hline YBWA-3 & 20051031 & $16: 40$ & 16.1 & 73 & 7.84 & 7.85 & 890 & 640 & 219 & 49 & 93.2 \\
\hline YBWA-4 & 20060522 & 17:00 & 24 & 245 & 9.83 & 9.35 & 434 & 281 & N.D. & N.D. & N.D. \\
\hline
\end{tabular}


Table 9. Mercury species in surface sediment (0-2 cm interval), Cache Creek and Yolo Bypass, Yolo County, California.

[concentrations expressed in dry weight; $\mathrm{THg}$, total mercury; $\mathrm{Hg}(\mathrm{II})_{\mathrm{R}}$, reactive inorganic mercury; $\mathrm{Hg}(\mathrm{II})_{\mathrm{R}}$ $(\%)$, ratio of $\mathrm{Hg}(\mathrm{II})_{\mathrm{R}}$ to $\mathrm{THg}$ in percent; $\mathrm{MeHg}$, methylmercury (concentration as $\mathrm{Hg}$ ); $\mathrm{MeHg}(\%)$, ratio of $\mathrm{MeHg}$ to $\mathrm{THg}$, in percent; $\mathrm{ng} / \mathrm{g}$, nanogram per gram; \%, percentage of $\mathrm{THg}$; analytical error based upon replicate ( $n=2$ to 4 ) measurements are given in parentheses ( ), when no error is expressed the number of analytical measurements was 1 ; N.D., not determined]

\begin{tabular}{ccccccc}
\hline Site Code & $\begin{array}{c}\text { Collection } \\
\text { Date }\end{array}$ & $\begin{array}{c}\mathrm{THg} \\
(\mathrm{ng} / \mathrm{g})\end{array}$ & $\begin{array}{c}\mathrm{Hg}(\mathrm{II})_{\mathrm{R}} \\
(\mathrm{ng} / \mathrm{g})\end{array}$ & $\mathrm{Hg}(\mathrm{II})_{\mathrm{R}}(\%)$ & $\begin{array}{c}\mathrm{MeHg} \\
(\mathrm{ng} / \mathrm{g})\end{array}$ & $\begin{array}{c}\mathrm{MeHg} \\
(\%)\end{array}$ \\
\hline
\end{tabular}

PHASE I: RECONNAISSANCE SAMPLING

\begin{tabular}{lccllll} 
CCNP-1 & 20051005 & $132(20)$ & $1.29(0.77)$ & $0.98(0.60)$ & 0.24 & 0.18 \\
CCNP-2 & 20051005 & $74(1)$ & $0.29(0.19)$ & $0.40(0.25)$ & 0.56 & 0.75 \\
CCSB-1 & 20051005 & 959 & $1.96(0.87)$ & $0.20(0.09)$ & 0.66 & 0.07 \\
YBWA-1 & 20051005 & $375(5)$ & 6.78 & $1.81(0.03)$ & 1.22 & 0.33 \\
YBWA-2 & 20051005 & $125(6)$ & $7.87(0.57)$ & $6.28(0.54)$ & 0.42 & 0.34 \\
PHASE II: SEASONAL SAMPLING & & & & \\
CCSB-2 & 20060213 & $231(24)$ & N.D. & N.D. & $0.37(0.01)$ & 0.16 \\
CCSB-2 & 20060530 & $182(57)$ & $0.44(0.15)$ & $0.24(0.11)$ & $1.00(0.33)$ & 0.55 \\
CCSB-3 & 20060213 & $319(99)$ & N.D. & N.D. & $0.35(0.01)$ & 0.11 \\
CCSB-3 & 20060530 & $319(59)$ & $1.28(0.15)$ & $0.40(0.09)$ & $0.23(0.03)$ & 0.07 \\
YBWA-1 & 20051031 & $243(56)$ & N.D. & N.D. & 1.37 & 0.56 \\
YBWA-1 & 20060522 & $343(28)$ & 0.67 & $0.20(0.02)$ & 1.49 & 0.43 \\
YBWA-2 & 20051031 & $94(4)$ & N.D. & N.D. & 1.90 & 2.01 \\
YBWA-2 & 20060522 & $172(14)$ & 0.22 & $0.13(0.01)$ & 1.47 & 0.86 \\
\hline
\end{tabular}


Table 10. Ancillary parameters in the surface sediment (0-2 cm interval), Cache Creek and Yolo Bypass, Yolo County, California.

[All analyte concentrations expressed on a dry weight basis; Dry wt., sediment dry weight; bulk density, in sediment weight per volume; porosity, in volume of pore water per volume of whole sediment; LOI, weight loss on ignition at $450^{\circ} \mathrm{C}$ (a measure of organic content); AVS, acid volatile sulfur; Fe(II) ${ }_{\mathrm{AE}}$, acid extractable ferrous iron; $\mathrm{Fe}(\mathrm{III})_{\mathrm{a}}$, acid extractable amorphous (poorly crystalline) ferric iron; $\mathrm{Fe}(\mathrm{III})_{\mathrm{c}}$, crystalline ferric iron; $\mathrm{E}_{\mathrm{h}}$, sediment oxidation-reduction potential corrected for the standard hydrogen half-cell reaction; \%, percentage; $\mathrm{g} / \mathrm{cm}^{3}$, grams per cubic centimeter; $\mathrm{mL} / \mathrm{cm}^{3}$, milliliters per cubic centimeter; $\mu \mathrm{mol} / \mathrm{g}$, micromole per gram; $\mathrm{mg} / \mathrm{g}$, milligrams per gram; $\mathrm{mV}$, millivolts; analytical error based upon replicate $(\mathrm{n}=2)$ measurements is given in parentheses $(\mathrm{)}$, when no error is expressed the number of analytical measurements was 1; N.D., not determined; measurements below the analytical detection limit are indicated with ' $<$ ' and the detection limit value.]

\begin{tabular}{|c|c|c|c|c|c|c|c|c|c|c|c|}
\hline Site Code & $\begin{array}{c}\text { Field } \\
\text { Collection } \\
\text { Date }\end{array}$ & $\begin{array}{c}\text { Dry wt. } \\
(\%)\end{array}$ & $\begin{array}{c}\text { Bulk Density } \\
\left(\mathbf{g} / \mathrm{cm}^{3}\right)\end{array}$ & $\begin{array}{l}\text { Porosity } \\
\left(\mathbf{m L} / \mathrm{cm}^{3}\right)\end{array}$ & $\begin{array}{l}\text { LOI } \\
(\%)\end{array}$ & $\begin{array}{c}\text { AVS } \\
(\mu \mathrm{mol} / \mathrm{g})\end{array}$ & $\begin{array}{l}\mathrm{Fe}(I I)_{\mathrm{AE}} \\
(\mathrm{mg} / \mathrm{g})\end{array}$ & $\begin{array}{l}\mathrm{Fe}(I I I)_{a} \\
(\mathrm{mg} / \mathrm{g})\end{array}$ & $\begin{array}{l}\mathrm{Fe}(I I I)_{\mathrm{c}} \\
(\mathrm{mg} / \mathrm{g})\end{array}$ & $(\mathrm{mV})$ & $\mathrm{pH}$ \\
\hline \multicolumn{12}{|c|}{ PHASE I: RECONNAISSANCE SAMPLING } \\
\hline CCNP-1 & 20051005 & $40.0(0.8)$ & $1.28(0.01)$ & $0.77(0.00)$ & $6.7(0.0)$ & $19.6(5.2)$ & $7.37(0.67)$ & $0.72(0.23)$ & $<0.1$ & 82 & 6.96 \\
\hline CCNP-2 & 20051005 & $39.2(0.1)$ & $1.28(0.02)$ & $0.78(0.01)$ & $5.9(0.4)$ & $30.1(1.9)$ & $9.69(0.37)$ & $0.52(0.37)$ & $<0.1$ & 72 & 6.86 \\
\hline CCSB-1 & 20051005 & $53.7(0.5)$ & $1.44(0.02)$ & $0.67(0.00)$ & $9.4(0.3)$ & $20.2(0.8)$ & $8.54(0.08)$ & $0.75(0.06)$ & $<0.1$ & 72 & 7.09 \\
\hline YBWA-1 & 20051005 & $51.4(0.1)$ & $1.42(0.01)$ & $0.69(0.01)$ & $7.5(0.5)$ & $1.3(0.9)$ & $7.45(0.03)$ & $3.97(0.33)$ & $2.41(0.13)$ & 145 & 7.20 \\
\hline YBWA-2 & 20051005 & $64.1(0.9)$ & $1.55(0.03)$ & $0.56(0.00)$ & $6.9(0.0)$ & $0.7(0.2)$ & $1.77(0.03)$ & $3.29(0.13)$ & $3.73(0.51)$ & 187 & 7.27 \\
\hline \multicolumn{12}{|c|}{ PHASE II: SEASONAL SAMPLING } \\
\hline CCSB-2 & 20060213 & $47.7(0.1)$ & $1.41(0.01)$ & $0.74(0.00)$ & $3.3(0.3)$ & $1.3(0.5)$ & 2.52 & 0.20 & N.D. & N.D. & 8.11 \\
\hline CCSB-2 & 20060530 & $64.4(1.2)$ & $1.58(0.06)$ & $0.56(0.04)$ & $2.8(0.5)$ & $2.6(1.2)$ & $3.03(0.05)$ & $0.41(0.05)$ & $7.98(0.19)$ & N.D. & N.D. \\
\hline CCSB-3 & 20060213 & $48.7(2.2)$ & $1.41(0.02)$ & $0.72(0.02)$ & $2.9(0.3)$ & $1.0(0.1)$ & $1.80(0.09)$ & $0.71(0.11)$ & N.D. & N.D. & 8.11 \\
\hline CCSB-3 & 20060530 & $73.4(1.4)$ & $1.77(0.01)$ & $0.47(0.02)$ & $1.6(0.3)$ & $0.3(0.1)$ & $0.72(0.01)$ & $0.98(0.02)$ & $8.35(0.04)$ & N.D. & N.D. \\
\hline YBWA-1 & 20051031 & $41.1(1.9)$ & $1.32(0.02)$ & $0.78(0.01)$ & $6.8(0.1)$ & N.D. & N.D. & N.D. & N.D. & 98 & 6.92 \\
\hline YBWA-1 & 20060522 & $47.2(0.4)$ & $1.37(0.02)$ & $0.72(0.01)$ & $6.4(0.5)$ & $9.0(0.4)$ & $8.47(0.66)$ & $0.16(0.13)$ & $10.31(0.48)$ & N.D. & N.D. \\
\hline YBWA-2 & 20051031 & $48.2(0.5)$ & $1.39(0.01)$ & $0.72(0.01)$ & $7.7(0.3)$ & N.D. & N.D. & N.D. & N.D. & 86 & 6.91 \\
\hline YBWA-2 & 20060522 & $49.0(0.9)$ & $1.38(0.03)$ & $0.70(0.01)$ & $6.7(0.1)$ & $11.0(1.7)$ & $6.37(0.48)$ & $0.12(0.00)$ & $6.98(0.44)$ & N.D. & N.D. \\
\hline
\end{tabular}


Table 11. Ancillary parameters in sediment pore water (0-2 cm interval), Cache Creek and Yolo Bypass, Yolo County, California.

[DOC, dissolved organic carbon; $\mathrm{Fe}(\mathrm{II})$, filter-passing ferrous iron; $\mathrm{SO}_{4}{ }_{4}^{2-}$, dissolved sulfate; $\mathrm{Cl}^{-}$, dissolved chloride; $\mathrm{mg} / \mathrm{L}$, milligrams per liter; $\mu \mathrm{mol} / \mathrm{L}$, micromoles per liter; analytical error based upon replicate $(n=2)$ measurements is given in parentheses () , when no error is expressed the number of analytical measurements was 1; N.D., not determined; measurements below the analytical detection limit are indicated with '<' and the method limit]

\begin{tabular}{|c|c|c|c|c|c|c|c|}
\hline $\begin{array}{r}\text { Site } \\
\text { Code }\end{array}$ & $\begin{array}{c}\text { Field } \\
\text { Collection } \\
\text { Date }\end{array}$ & $\mathrm{DOC}$ (mg/L) & $\mathrm{Fe}(\mathrm{II})(\mathrm{mg} / \mathrm{L})$ & $\mathrm{SO}_{4}{ }^{2-}(\mu \mathrm{mol} / \mathrm{L})$ & $\mathrm{Cl}^{-}(\mu \mathrm{mol} / \mathrm{L})$ & $\begin{array}{l}\text { Acetate } \\
(\mu \mathrm{mol} / \mathrm{L})\end{array}$ & $\begin{array}{c}\text { Sulfide } \\
(\mu \mathrm{mol} / \mathrm{L})\end{array}$ \\
\hline \multicolumn{8}{|c|}{ PHASE I: RECONNAISSANCE SAMPLING } \\
\hline CCNP-1 & 20051005 & $178(8)$ & $4.9(0.1)$ & $0.85(0.08)$ & $1055(32)$ & $70.9(12.4)$ & $0.81(0.14)$ \\
\hline CCNP-2 & 20051005 & $147(11)$ & $2.4(0.1)$ & $1.1(0.2)$ & $748(16)$ & $30.7(1.6)$ & $0.56(0.05)$ \\
\hline CCSB-1 & 20051005 & N.D. & $0.53(0.04)$ & $87(6)$ & $1195(22)$ & 73.3 & $0.41(0.00)$ \\
\hline YBWA-1 & 20051005 & 93 & $<0.1$ & $1011(24)$ & $2556(36)$ & $55.2(50.9)$ & $0.35(0.01)$ \\
\hline YBWA-2 & 20051005 & N.D. & $<0.2$ & $929(23)$ & $1844(27)$ & $14.0(7.6)$ & $0.33(0.03)$ \\
\hline \multicolumn{8}{|c|}{ PHASE II: SEASONAL SAMPLING } \\
\hline CCSB-2 & 20060213 & $3.9(0.4)$ & $<0.1$ & $113(3)$ & $652(3)$ & N.D. & $0.46(0.03)$ \\
\hline CCSB-2 & 20060530 & 3.3 & $<0.1$ & $187(1)$ & $1091(7)$ & N.D. & 0.83 \\
\hline CCSB-3 & 20060213 & $3.3(0.1)$ & $<0.1$ & $137(2)$ & 724 (2) & N.D. & $0.45(0.01)$ \\
\hline CCSB-3 & 20060530 & 4.7 & $<0.1$ & 249 & 1122 & N.D. & 2.64 \\
\hline YBWA-1 & 20051031 & N.D. & N.D. & N.D. & N.D. & N.D. & N.D. \\
\hline YBWA-1 & 20060522 & $6.1(0.8)$ & $2.6(0.3)$ & $0.10(0.06)$ & $288(0)$ & N.D. & $1.90(0.11)$ \\
\hline YBWA-2 & 20051031 & N.D. & N.D. & N.D. & N.D. & N.D. & N.D. \\
\hline YBWA-2 & 20060522 & $10.9(0.5)$ & $3.0(0.1)$ & $1.0(0.9)$ & $305(0)$ & N.D. & $2.87(0.63)$ \\
\hline
\end{tabular}

